UNIVERSIDADE DE BRASÍLIA - UnB INSTITUTO DE CIÊNCIAS SOCIAIS - ICS

CENTRO DE PESQUISA E PÓS-GRADUAÇÃO SOBRE AS AMÉRICAS CEPPAC

PROGRAMA DE PÓS-GRADUAÇÃO EM ESTUDOS COMPARADOS SOBRE AS AMÉRICAS

Cledinei Carneiro Zavaski

APROPRIAÇÃO E PRIVATIZAÇÃO DE TERRITÓRIOS NO BRASIL E PARAGUAI: RELAÇÃO DEPENDENTE E SUBIMPERIALISMO 
UNIVERSIDADE DE BRASÍLIA - UnB

INSTITUTO DE CIÊNCIAS SOCIAIS - ICS

CENTRO DE PESQUISA E PÓS-GRADUAÇÃO SOBRE AS AMÉRICAS CEPPAC

PROGRAMA DE PÓS-GRADUAÇÃO EM ESTUDOS COMPARADOS SOBRE AS AMÉRICAS

Cledinei Carneiro Zavaski

\section{APROPRIAÇÃO E PRIVATIZAÇÃO DE TERRITÓRIOS NO BRASIL E PARAGUAI: RELAÇÃO DEPENDENTE E SUBIMPERIALISMO}

Dissertação apresentada ao Centro de Pesquisa e Pós-Graduação sobre as Américas como parte dos requisitos para a obtenção do título de Mestre.

Orientador: Prof. Dr. Martin-Léon-Jacques Ibáñez de Novion 
Para Eloiza Soares Nascimento, minha Companheira. Para O Movimento dos Trabalhadores Rurais Sem Terra, minha Organização. Para os trabalhadores, especialmente brasileiros e paraguaios, minha Classe. Para aqueles e aquelas que lutam por uma sociedade comunista, minha Vida. 


\section{AGRADECIMENTO}

Primeiramente gostaria de agradecer a minha família, ao meu pai Luiz Carlos e a minha mãe Eunice, ao meu irmão Cleberson e às minhas irmãs Josiane e Josielle, aos meus cunhados e cunhadas, aos meus sobrinhos e sobrinhas, à minha sogra e a minha maravilhosa Companheira Eloiza. Todos depositaram em mim um sonho, como único Mestre da família até aqui. Eloiza em especial, que foi amiga, parceira, companheira e o apoio sem o qual não teria chegado até aqui.

Agradeço em especial aos professores e ao próprio CEPPAC como instituição, por terem criado um ambiente favorável ao debate científico, aprofundando a perspectiva dos Estudos Latino-americanos. A professora Rebecca Igreja que muito contribuiu na superação dos limites metodológicos de um Engenheiro Agrônomo que se aventura nas Ciências Sociais e, especialmente, ao professor Jacques de Novion, que além de orientador, coloca-se junto, nas fileiras de luta pela transformação social. Ao professor e companheiro Manoel, pela convivência nos debates da Questão Agrária e por ter prontamente se disposto a ler e contribuir na melhoria desse trabalho.

Um profundo agradecimento, devo aos companheiros, amigos e intelectuais da Teoria Marxista da Dependência, do GT-TMD da SEP e dos vários grupos e locais que nos encontramos nessa construção coletiva de uma "análise concreta da realidade concreta" buscando a transformação. Incorreria em faltas se citasse algum, mas acredito que agradecer simbolicamente ao nosso querido mestre Reinaldo Carcanholo (in memoriam) representa a cada um.

Agradeço também aos companheiros e companheiras do Movimento dos Trabalhadores Rurais Sem Terra - MST, que souberam desculpar minhas faltas nas tarefas do ultimo período, além de ser a organização fundamental que me possibilita ser sujeito do processo estudado nessa dissertação. 


\section{RESUMO}

A apropriação do território e organização da produção agrícola no Brasil e no Paraguai, posteriormente a colonização, seguiu sempre subordinada ao desenvolvimento do capitalismo de forma geral e do capitalismo dependente em específico. A condição de Dependência dos países periféricos forneceu características específicas em cada país. Nesse, sentido o presente trabalho tem o objetivo de elucidar os elementos históricosteóricos da apropriação do território nos dois países e as relações que se estabelecem nesse processo. Tais elementos foram extraídos do estudo da Questão Agrária e da Teoria Marxista da Dependência. Concluindo que o Brasil se apropriou de parcelas significativas do território paraguaio numa relação de Dependência e Subimperialismo, que na atualidade tem o objetivo central na apropriação da Renda da Terra no Paraguai pelo Capital brasileiro.

Palavras-chave: Dependência; Subimperialismo; Renda da Terra; Agronegócio. 


\begin{abstract}
The appropriation of territory and organization of agricultural production in Brazil and Paraguay later colonization, followed always subordinate the development of capitalism in general and in specific dependent capitalism. The dependency condition of the peripheral countries provided specific characteristics in each country. In this, meaning the present study aims to elucidate the historical-theoretical elements of the territory's ownership in the two countries and the relations established in this process. These elements were taken from the study of Agrarian Question and the Marxist theory of dependency. Concluding that Brazil has appropriated significant portions of the Paraguayan territory in a relationship of dependency and sub-imperialism, which today has the main objective on Earth Income ownership in Paraguay by the Brazilian Capital.
\end{abstract}

Keywords: Dependency; sub-imperialism; Income from Earth; Agribusiness. 


\section{LISTA DE ABREVIATURAS E SIGLAS}

ABRA - Associação Brasileira de Reforma Agrária

ANR - Asociación Nacional Republicana

APP - Área de Preservação Permanente

BNCC - Banco Nacional de Crédito Cooperativo

CAN - Censo Nacional Agropecuário

CEPAL - Comissão Econômica para a América Latina e o Caribe

CFP - Comissão de Financiamento da Produção

CIBRAZEM - Companhia Brasileira de Armazenamento

COBAL - Companhia Brasileira de Alimentos

CONAB - Companhia Nacional de Abastecimento

CTRIN-DTRIG - Centro do Trigo Nacional do Banco do Brasil - Departamento do

Trigo Nacional da SUNAB

EMBRATER - Empresa Brasileira de Assistência Técnica e Extensão Rural

EMBRAPA - Empresa Brasileira de Pesquisa Agropecuária

ESG - Escola Superior de Guerra

FAO - Organização das Nações Unidas para a Alimentação e Agricultura

FHC - Fernando Henrique Cardoso

GT-TMD - Grupo de Trabalho de Teoria Marxista da Dependência

IAA - Instituto do Açúcar e do Álcool

IBC - Instituto Brasileiro do Café

IBGE - Instituto Brasileiro de Geografia e Estatística

INCRA - Instituto Nacional de Colonização e Reforma Agrária

INSS - Instituto Nacional do Seguro Social

IPEA - Instituto de Pesquisa Econômica Aplicada

Ligas - Ligas Camponesas

MASTER - Movimento de Agricultores Sem Terra

MPAS - Grupo de Pesquisa Modos de Produção e Antagonismos Sociais

MS - Mato Grosso do Sul

MST - Movimento dos Trabalhadores Rurais Sem Terra

ONU - Organização das Nações Unidas

PAC - Programa de Ayuda Cristiana

PC - Partido Comunista 
PCB - Partido Comunista Brasileiro

PGPN - Política de Garantia de Preços Mínimos

PIB - Produto Interno Bruto

PSB - Partido Socialista Brasileiro

PT - Partido dos Trabalhadores

RL - Reserva Legal

SEP - Sociedade Brasileira de Economia Política

SNCR - Sistema Nacional de Crédito Rural

SUNAB - Superintendência Nacional de Abastecimento

TI - Território Indígena

TMD - Teoria Marxista da Dependência

UC - Unidade de Conservação

ULTAB - União dos Lavradores e Trabalhadores Agrícolas do Brasil 


\section{LISTA DE TABELAS}

Tabela 1: formação do lucro médio e transferência de valor.........................................59 


\section{SUMÁRIO}

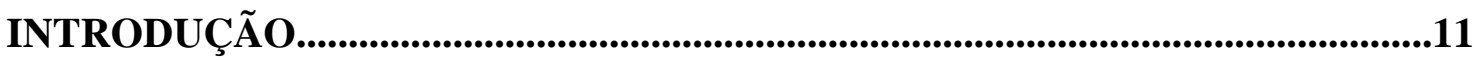

1. APROPRIAÇÃO DA TERRA NO BRASIL - DA EXPANSÃO DO CAPITAL MERCANTIL AO AGRONEGÓCIO...................................................................17

1.1. América sem a Colonização.......................................................................18

1.2. A Colonização - Hegemonia do Capital Mercantil............................................20

1.3. Crise do Modelo Agroexportador - Hegemonia do Capital Industrial..............27

1.4. Crise do Modelo da Modernização Conservadora - Hegemonia do

Capital Financeiro. .39

2. A INSERÇÃo dOS PAÍSES PERIFÉRICOS E A BUSCA PELA

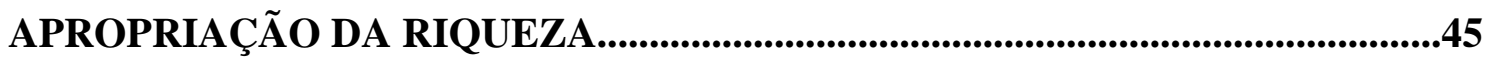

2.1. O Subdesenvolvimento e a Dependência - Da Cepal à Teoria Marxista da

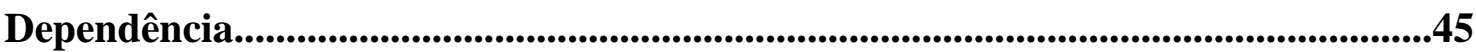

2.2. A Interpretação Marxista - Teoria Marxista da Dependência...........................54

2.3. Mecanismos de Compensação da Dependência.......................................................64

2.3.1. Superexploração da Força de Trabalho..............................................64

2.3.2. Subimperialismo...................................................................................................66

3. DOMÍNIO ECONOMICO E APROPRIAÇÃO DAS TERRAS DO PARAGUAI

PELO CAPITAL BRASILEIRO............................................................................76

3.1. Hegemonia do Capital Financeiro na Agricultura - Economia do

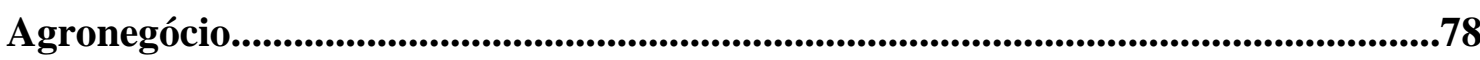

3.2. Consolidação da Hegemonia Brasileira e Apropriação das Terras no

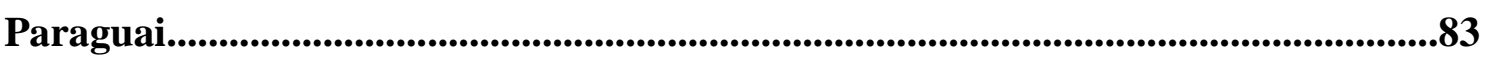

3.3. Crescimento para Fora - Dependência para Dentro.........................................94

3.4. A Determinação do Agronegócio Brasileiro no Paraguai.................................101

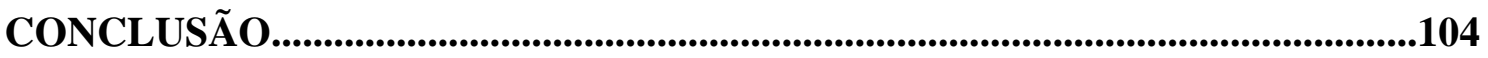

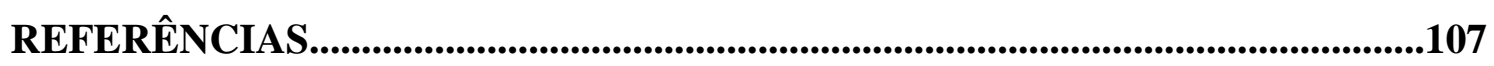




\section{INTRODUÇÃO}

A presente dissertação de mestrado tem por objetivo compreender a forma de apropriação do território no Brasil e no Paraguai, com que características desenvolveuse no decorrer da história e que elementos determinam a sua conformação atual. $\mathrm{O}$ estudo foi realizado numa perspectiva multidisciplinar para a compreensão da realidade posta, valendo-se de elementos sociológicos, econômicos e políticos adotou-se duas chaves analíticas para a compreensão do fenômeno. A primeira delas dada pela Questão Agrária e todos os elementos que envolvem esse ramo do conhecimento, que busca compreender a forma que uma determinada sociedade organiza a posse, o uso e a propriedade da terra conjuntamente com a compreensão de como tal sociedade organiza a produção agrária. A outra chave analítica fundamental utilizada é a Teoria Marxista da Dependência, que traz os elementos fundamentais para a compreensão da inserção subordinada dos países dependentes no mercado mundial, as relações que estes estabelecem com os países centrais, entre sí e, entre as classes sociais internamente em cada país. Esses elementos são usados para a compreensão de como Brasil e Paraguai, no que refere-se à Apropriação dos territórios e organização da produção agrícola, estabelecem uma "Relação dependente e Subimperialista".

É importante iniciar a apresentação deste trabalho relatando como cheguei à esse objeto de pesquisa e à perspectiva de análise que foi adotada no tema.

O primeiro elemento relevante é a minha origem familiar, neto de imigrantes do leste europeu, por um lado, e de "bugres" pelo outro, sempre busquei a compreensão de minha real origem. Ao buscar compreender a vertente europeia de minha família não encontrei a origem num país determinado, como o fazem os italianos e alemães, depois de muitas conversas e pesquisas fui me descobrindo um camponês, um pouco russo, um pouco ucraniano, fugindo pela Polônia da fome, das guerras, da expropriação dos camponeses na segunda metade do século XIX, enfim, um fugitivo do desenvolvimento do Capitalismo na Europa. Nos primeiros anos no Novo Mundo, novamente o desenvolvimento do Capitalismo influenciou os rumos da minha família, a colonização realizada pela empresa inglesa Lumber no Estado de Santa Catarina e a derrota dos camponeses na Guerra do Contestado despojou-os das posses de terras, proletarizandoos. Assim chego a mim, neto de um ferroviário russo e uma cabelereira ucraniana, filho 
de um operário que virou vendedor. De outro lado, buscando compreender minha origem materna, me descobri um brasileiro nato, surgido de um misto de portugueses, espanhóis, negros e com um forte traço guarani. Essa busca individual consolidou uma característica que apresenta-se na vida acadêmica, a busca da compreensão da história para a análise dos fenômenos.

Ainda muito novo migramos para o Oeste Paranaense, para a cidade de Cascavel, duas questões são particularmente influentes nas minhas opções intelectuais, políticas e aspirações de pesquisador. A primeira é que no final da década de 1980 e início da década de 1990, passando por fortes dificuldades econômicas, meu pai constantemente expressava: "Um dia vamos colocar tudo num caminhão e vamos embora para o Mato Grosso”. Não entendia muito o porque dessa expressão, hoje entendo ela estava diretamente ligada com a segunda questão. Morávamos num bairro da periferia e muito próximo, na saída da cidade, às margens de uma rodovia, havia um Acampamento Sem Terra. Muitos dos trabalhadores acampados ali prestavam serviços braçais na cidade e por muitas vezes ouvi serem chamados de Brasiguaios e Chirus. Somente com a presente pesquisa compreendi que o acampamento e a vontade de meu pai faziam parte do mesmo processo. No final dos anos de 1980, expulsos pelos latifundiários capitalistas brasileiros os camponeses brasileiros que tinham migrado para o Paraguai retornavam, muitos fortaleceram as fileiras da luta do Movimento dos Trabalhadores Rurais Sem Terra - MST no Paraná, outros, estavam sendo alocados pelo Governo em projetos de colonização no Mato Grosso. O Mato Grosso era uma nova esperança para os camponeses Brasiguaios, também era para meu pai.

Em minha vida acadêmica, essa constituição inicial, foi fundante: uma origem camponesa-proletária e a necessidade de compreender os "porquês" da realidade. Em 1998, estudante do Curso Técnico em Agropecuária pela Escola Agrotécnica Federal de Sertão - EAFS, no Rio Grande do Sul, atuando como advogado do MST, num julgamento simbólico, diante mais de 120 estudantes e professores, o latifúndio foi condenado pelo crime de atrasar o Brasil, usar de violência contra os camponeses e degradar o meio ambiente. Chamado de "Sem Terra" a partir de então conclú́ o Curso defendendo o Estágio realizado no Assentamento Ireno Alves dos Santos, município de Rio Bonito do Iguaçú, no Paraná, assentamento formado em sua maioria por camponeses sem terra brasiguaios. 
Os interesses pelos temas agrários e sociais mantiveram-se permanentes a partir de então, no ano de 2001 iniciei a Graduação em Agronomia, na Universidade Federal do Paraná - UFPR, nesse período fiz parte do Espaço Marx, grupo de estudos destinado ao estudo da obra de Karl Marx, onde sedimentei meus conhecimentos da Economia Política. Transferi-me para a Universidade Federal de Minas Gerais - UFMG em 2006, graduando-me em 2009 defendendo a monografia "Cooperação Agrícola em Assentamentos de Reforma Agrária no Norte de Minas Gerais: O Caso da Cooperativa Camponesa Veredas da Terra", onde dediquei-me a estudar os desafios do desenvolvimento a partir da ação dos trabalhadores numa esfera regional.

Logo compreendi que os problemas do desenvolvimento são mais complexos e era preciso uma compreensão mais ampla dos processos. Nesse sentido cursei a Pós Graduação em Economia e Desenvolvimento Agrário na Universidade Federal do Espírito Santo - UFES onde aprofundei o conhecimento sobre a Teoria Marxista da Dependência, corrente intelectual na qual me filio desde então. Recebi o título de especialista defendendo a pesquisa "Contradições no Bloco do Agronegócio: A disputa pela apropriação da mais-valia, a apropriação dos territórios e o aumento da exploração dos trabalhadores" onde defendi a tese de que o centro da disputa da burguesia agrária brasileira está no aumento da área de exploração para a apropriação de Renda da Terra.

A partir das inquietações despertadas na Especialização Latu Sensu em Economia e Desenvolvimento Agrário e, já com forte influência da TMD e da aproximação dos Estudos Latinoamericanos, dada principalmente pela curiosidade pessoal e a necessidade militante de compreender o processo de ascenso de governos progressistas em vários países da América Latina, apresentei o anteprojeto de pesquisa: “As estratégias de saídas para a crise através da apropriação dos territórios e recursos naturais pelo mercado - Subserviência ou Resistência?", onde me propunha a comparar e compreender as 'diferenças' entre processos de apropriação de territórios no Brasil e na Bolívia.

Participando do grupo de pesquisa Modos de Produção e Antagonismos Sociais (MPAS/UnB) realizei várias discussões sobre o estágio atual de desenvolvimento do capitalismo no campo com outros pesquisadores. A participação na Associação Brasileira de Reforma Agrária, e o contato com as formulações do economista 
Guilherme Delgado sedimentou alguns elementos fundamentais da Economia Política do Agronegócio. A participação no Grupo de Trabalho em Teoria Marxista da Dependência da Sociedade Brasileira de Economia Política (GT-TMD) propiciou mais um grande conjunto de elementos. As conversas frutíferas com intelectuais paraguaios nesse espaço, especialmente com a Cientista Social Cecilia Vuyk, juntaram-se as aspirações infantis de compreender as falas de meu pai e aquele acampamento de brasiguaios. O fato de o Brasil ser o segundo país com maior concentração da propriedade da terra, perdendo apenas para o Paraguai juntou-se como potencializador das escolhas. Todo esse processo alterou a proposta inicial e consolidou o tema dessa dissertação: "Apropriação de Territórios no Brasil e Paraguai: Relação Dependente e Subimperialismo”. Deixando para pesquisas futuras os processos específicos da Bolívia, seu Estado Plurinacional e a sua comparação com o Brasil.

O tema proposto apresenta uma enorme relevância em relação ao desenvolvimento do capitalismo no campo na América Latina em específico e ressalta de forma geral a importância dos Estudos Latino Americanos para a compreensão e transformação de nossa realidade. O tema desenvolvido nesse trabalho propõe uma análise a partir de uma observação sócio-histórica do desenvolvimento da apropriação do território nos dois países, quais os elementos foram determinantes e que impactos produziram nos aspectos econômicos, políticos e sociais. Além disso, não pode ser analisado sem uma perspectiva interdisciplinar, utilizando de interfaces e pontos de vista diferenciados de várias linhas do conhecimento para uma compreensão mais concreta do fenômeno. Outro elemento que ressalta a importância do estudo realizado e o fundamenta nas bases dos Estudos Latino-americanos é a perspectiva da transformação da realidade estudada. Dessa forma a análise realizada busca não somente compreender as características do fenômeno, mas apontar suas causas e possibilidades de superação.

O trabalho foi construindo dialogando os elementos do desenvolvimento do capitalismo no campo brasileiro, tendo na Questão Agrária as bases teóricas para a fundamentação e a inserção subordinada dos países periféricos no Mercado Mundial, aprofundando-se nas concepções da Teoria Marxista da Dependência. A análise da apropriação do território brasileiro e paraguaio e as relações de dependência e subimperialismo que se estabelece foram realizadas com base em estudos teóricos, 
assim, os elementos que comporiam uma possível pesquisa de campo, apenas aparecem de forma ilustrativa.

No primeiro capítulo, denominado "A apropriação do Território no Brasil - Da Expansão do Capital Mercantil ao Agronegócio”, é apresentado, a partir do estudo da Questão Agrária, um histórico da apropriação do território no Brasil e a forma de organização da produção agrícola, as características e transformações que mais de meio milênio desde a colonização produziram. É ressaltando nesse capítulo, em relação à Questão Agrária, a determinação predominante do Capital hegemônico em cada período.

No capítulo seguinte, onde tratamos "A Inserção dos Países Periféricos e a Busca da Apropriação de Riquezas”, desenvolve-se a fundamentação teórico-histórica, com base na Teoria Marxista da Dependência, da forma de inserção dos países periféricos no mercado mundial, ressaltando-se a transferência de valor para o centro capitalista, que fundamenta a Dependência. Aprofunda-se nos elementos de compensação das perdas das burguesias internas através dos mecanismos da superexploração do trabalho e do subimperialismo exercido por países menos periféricos, no caso o Brasil, sobre países mais periféricos, o Paraguai, num processo de cooperação antagônica com o imperialismo estadunidense.

O terceiro capítulo é reservado à compreensão do "Domínio Econômico e Apropriação das Terras Paraguaias pelo Capital Brasileiro”, para tal avançamos ainda na elucidação do estágio atual do capitalismo no campo brasileiro e posteriormente no processo histórico de subordinação econômica e apropriação do território paraguaio desenvolvido pelo subimperialismo brasileiro alinhado ao imperialismo estadunidense em cooperação, com a elite paraguaia.

Concluímos com o estudo realizado que a apropriação dos territórios no Brasil e Paraguai seguiu, desde a colonização, subordinada ao desenvolvimento do capitalismo de forma geral e o capitalismo dependente de forma específica. $\mathrm{O}$ território paraguaio foi ocupado pelo Capital brasileiro no período posterior a Guerra da Tríplice-Aliança, mas consolidou-se na fase subimperialista brasileira sob a aliança das ditaduras dos dois países. O Brasil por um lado, buscava superar o anacronismo de seu desenvolvimento dependente explorando o território e o mercado paraguaio, além de distencionar a luta 
pela terra através da transposição de camponeses brasileiros para o Paraguai. A burguesia paraguaia, por sua vez desejava tornar-se sócia subordinada do subimperialismo brasileiro e apropriar-se de parte da riqueza produzida no campo paraguaio.

Para o desenvolvimento desse processo as classes camponesas brasileira e paraguaia foram utilizadas e descartadas conforme os projetos das elites, chegando à situação atual dos latifundiários capitalistas brasileiros dominarem vastas extensões de das terras no Paraguai.

O atual estágio de desenvolvimento do capitalismo, engendra no campo uma Economia Política do Agronegócio que para continuar o processo de valorização do Capital necessita apropriar-se cada vez mais das Rendas de Monopólio, em especial da Renda da Terra, para isso é necessário ampliar a fronteira de exploração capitalista e manter os domínios estabelecidos. No Brasil isso impacta num avanço da burguesia agrária sobre os Territórios Camponeses (Assentamentos, Quilombos, Comunidades Tradicionais), Indígenas, Unidades de Conservação e Áreas de Preservação. Em relação ao Paraguai, a burguesia agraria brasileira, busca manter seus domínios territoriais, apropriando-se da Renda da Terra extraída deles. Provém desta busca, o apoio irrestrito dos ruralistas brasileiros ao Golpe dado contra o presidente eleito Fernando Lugo em junho de 2012, que em seu Plano de Governo, incluiu a Reforma Agrária e a revisão do Acordo de Itaipu.

Submete-se assim, mais uma vez, o desenvolvimento paraguaio aos interesses dos Capitais brasileiros e a manutenção da sua condição dependente. Afirmando o exposto por Marini, que a Dependência só pode ser superada com a superação das relações de produção que a criam, ou seja, a superação do Capitalismo. 


\section{APROPRIAÇÃo DA TERRA NO BRASIL - DA EXPANSÃo DO CAPITAL MERCANTIL AO AGRONEGÓCIO}

Na perspectiva da formação da América Latina que conhecemos, a história de sua conformação, posteriormente à invasão europeia, configura-se profundamente através dos elementos estabelecidos em sua questão agrária. Para título de tal afirmação que permeará todo esse trabalho, Questão Agrária é definida como:

“(...) área do conhecimento humano que se dedica a
estudar, pesquisar e conhecer a natureza dos problemas
das sociedades em geral relacionados ao uso, a posse e a
propriedade da terra." (STÉDILE in CALDART et all,
2012 p. 639)

A forma de exploração do território e as relações de produção que se estabeleceram são a chave para a compreensão dos processos econômicos e sociais daí decorrentes.

Nesse sentido é importante discorrer sobre dois elementos essenciais para o desenvolvimento da Questão Agrária no Brasil, tal seja, o primeiro refere-se à etapa de desenvolvimento do capitalismo a nível mundial e como esse sistema organiza a produção inicialmente nas colônias e posteriormente nos países periféricos e dependentes. $\mathrm{O}$ segundo elemento trata de como essa forma de produção desenvolve a apropriação do território, que características são especificas dos países dependentes e de cada fase de desenvolvimento do capitalismo.

Ainda é necessário, a compreensão de um terceiro elemento, que será tratado em um Capítulo próprio, de como a inserção no mercado mundial gera características específicas de organização da produção agrícola e apropriação dos territórios nos países periféricos e, como alguns países se configuram como centros periféricos e reproduzem determinadas formas nos países mais periféricos.

Para a análise da Questão Agrária nos utilizaremos dos conceitos presentes nas compilações realizadas por Stédile na coleção "A Questão Agrária no Brasil”, que sintetizam e expõem uma perspectiva de análise a partir de uma interpretação intelectual-teórica e social-militante da realidade. 


\subsection{América sem a Colonização}

A questão agrária do território que veio posteriormente a conformar-se como o Brasil remonta a ocupação pelos primeiros seres humanos e como estes estabeleceram relação com a terra e com o território. Essa ocupação, ainda hoje em discussão entre historiadores, configurou-se por volta de 50 milênios atrás, conforme pesquisas antropológicas citadas pelo economista e líder social João Pedro Stédile, o autor afirma que "há fortes indícios de que a sociedade brasileira foi sendo formada e nosso território começou a ser habitado há 50 mil anos" (STÉDILE, 2005. p. 18).

Desse passado distante até o ano de 1500, marco da colonização portuguesa e da introdução de novas relações de produção, baseada no trabalho escravo e na apropriação privada da terra e dos recursos naturais, a sociedade humana organizou-se no que podemos chamar de Modo de Produção Comunista Primitivo, conforme nos confirma Stédile:

\section{"Para efeito de estudo da questão agrária nesse período, sabe-se que esses povos viviam no modo de produção do comunismo primitivo." (STÉDILE, 2005. p. 18)}

Como bases desse modo de produção os povos existentes no território seguiam dois princípios fundamentais. O primeiro princípio é o do trabalho coletivo, ou seja, todos os membros da sociedade deveriam atuar na produção de alimentos e demais necessidades do grupamento, essa característica é fundante de uma sociedade sem classes, tal seja o comunismo. O antropólogo Darcy Ribeiro nos confirma tal característica, afirmando que os conglomerados que chegavam a alcançar 3 mil pessoas:

"Eram, todavia, conglomerados pré-urbanos (aldeias
agrícolas indiferenciadas), porque todos os moradores
estavam compelidos a produção de alimentos, só
liberando dela, excepcionalmente, alguns líderes
religiosos (pajés e caraíbas) e uns poucos chefes
guerreiros (taxauas)." (RIBEIRO, 2006. p. 29)

O outro elemento fundamental no que tange a questão agrária é a posse e uso da terra. Para esses povos a posse e uso da terra e do território, era coletiva e tribal, havendo conflitos pela posse de um território entre clãs apenas de forma esporádica, “causados por disputas pelos sítios mais apropriados à lavoura, à caça e a pesca". (RIBEIRO, 2006. p. 30) 
Stédile é mais categórico na afirmação de tal apropriação coletiva do território e dos recursos naturais. Afirmando que:

\begin{abstract}
"Não havia entre eles qualquer sentido ou conceito de propriedade dos bens da natureza. Todos os bens da natureza existentes no território - terra, águas, rios, fauna, flora - eram, todos, de posse e de uso coletivo e eram utilizados com a única finalidade de atender às necessidades de sobrevivência social do grupo." (STÉDILE, 2005. p. 19)
\end{abstract}

Essa formação econômica-social baseada no modo de produção comunista primitivo e na organização social em clãs ou tribos, em sua maioria nômade, mesmo sem desenvolver muito a agricultura, ocupou todo o território onde se conformou o Brasil e prosperou. Sobre isso Stédile, afirma que, "como a natureza era pródiga no fornecimento de alimentos para suas necessidades básicas, os povos de nosso território pouco desenvolveram a agricultura.” (STÉDILE, 2005. p. 18)

Quando os europeus invadiram esse território, os colonizadores encontraram cerca de 5 milhões de habitantes divididos em 300 povos diferentes, mas que viviam mais ou menos na mesma forma de organização econômica-social, ou seja, mais que o dobro da população de Portugal à época (RIBEIRO, 2006. p. 28) vivendo sem os conceitos de apropriação privada e exploração do trabalho. Stédile afirma que:

\footnotetext{
"Quando os colonizadores europeus invadiram nosso território, estima-se que havia mais de 300 grupos tribais ocupando nosso território para a sua sobrevivência, num total de aproximadamente 5 milhões de pessoas." (STÉDILE, 2005. p. 19).
}

Ribeiro, citando o sociólogo Florestan Fernandes, afirma que somente na matriz Tupi:

\footnotetext{
"Somavam, talvez, 1 milhão de índios, divididos em dezenas de grupos tribais, cada um deles compreendendo um conglomerado de várias aldeias de trezentos à dois mil habitantes (Fernandes 1949). Não era pouca gente, porque Portugal aquela época teria a mesma população ou pouco mais.” (RIBEIRO, 2006. p. 28)
}

O período que segue a invasão portuguesa caracteriza-se pela subordinação dos povos originários e a implantação de um modelo de exploração com características distintas das até então existentes. 


\subsection{A Colonização - Hegemonia do Capital Mercantil}

A invasão e domínio de territórios desenvolvidas pelos europeus nos séculos XIII à XV insere-se no ciclo de expansão e consolidação do poder do capital mercantil, sendo a inserção da América Latina em específico feita a partir do século XV. As navegações eram financiadas pelos grandes comerciantes da Europa e buscavam basicamente mercadorias para serem comercializadas e realizarem um lucro mercantil. Stédile afirma que:

\footnotetext{
"Os portugueses que aqui chegaram e invadiram nosso território, em 1500, o fizeram financiados pelo nascente capitalismo comercial europeu,..." (STÉDILE, 2005. p. 19)
}

As características diferenciadas de desenvolvimento e objetivo confrontaram dois modos de produção distintos. Os europeus, já sob a égide do capitalismo mercantil, derrotaram os povos originários, organizados em formas de produção predominantemente comunitárias e sem a existência da apropriação privada. Para Marx "a contradição entre esses dois sistemas econômicos diametralmente opostos se patenteia, na prática, na luta que se trava entre eles" (MARX, 2013. p.889). Os colonizadores vitoriosos se apropriaram de todo o território e o submeteram à organização capitalista, Stédile afirma que com as táticas de cooptação e repressão, os portugueses, “...,conseguiram dominar todo o território e submeter os povos que aqui viviam ao seu modo de produção, às suas leis e à sua cultura. (STÉDILE, 2005. p. 19).

A apropriação do território e a organização da produção passam, a partir do domínio português, a se organizarem pelas leis do capitalismo mercantil já hegemônico na Europa. Apoiando-se no poder dos países colonizadores os capitalistas organizam o roubo e o saque das riquezas do território colonizado. Marx afirma que:

\footnotetext{
"Quando o capitalista se apoia no poder da pátria-mãe, procura afastar do caminho, pela força, o modo de produzir os bens e apropriar-se deles, baseado no trabalho próprio.” (MARX, 2013. p. 889)
}

$\mathrm{O}$ autor nessa passagem refere-se ao trabalho próprio como do produtor individual, ou seja, o artesão, assim está tratando de afirmar que pela força o capitalista subjuga o trabalho artesanal vinculado ao consumo, deixando em seu lugar o trabalho assalariado e separando o trabalhador do resultado final do seu trabalho. Essa mesma lógica de subjugação pode ser expandida para o produtor coletivo comunal das 
comunidades indígenas, separando essas dos meios para produzir a sua vida, a terra e or recursos naturais.

Dois elementos são importantes para a compreensão desse processo, a característica central da acumulação de capital no capitalismo mercantil, o lucro mercantil e, a forma que esse território, posteriormente conformado em país, se insere no mercado mundial.

O capitalismo mercantil caracteriza-se por manter-se na esfera da circulação de mercadorias e obtêm lucros através de vantagens comerciais estabelecidas nesse processo. Nesse sentido o elemento central do capitalismo mercantil é obter e comercializar o maior número de mercadorias possíveis, obtendo assim o maior lucro auferível. É uma característica importante, além da quantidade, a disponibilidade e o domínio das fontes dessas mercadorias, ou seja, quanto mais escassa uma mercadoria e quanto mais monopolizado for a sua forma de obtenção, tanto maior será o lucro mercantil do seu mercador. O historiador Rodney Hilton afirma que:

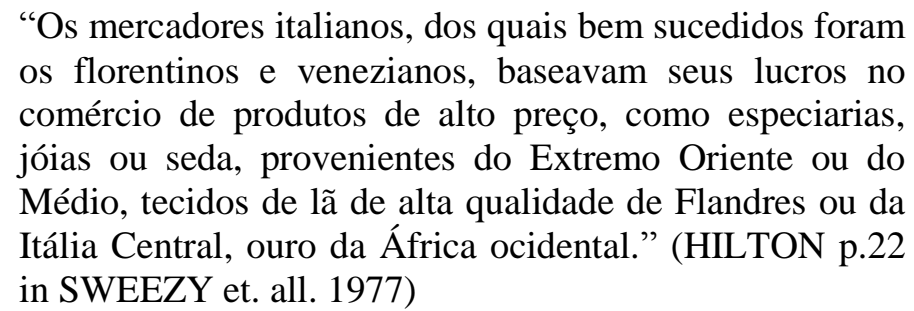

Assim, nos confirma Hilton que os capitalistas mercantis que mais prosperaram foram, sem dúvida, aqueles que conseguiram obter as maiores vantagens na busca de mercadorias e na comercialização destas na Europa. O lucro mercantil, obtido pela diferença do preço de compra e do preço de venda, é o elemento central do capitalismo mercantil. Isso quando existe um preço de compra, pois em muitas das transações desse período o lucro mercantil advém não da conta anterior, mas da diferença do custo de saque e roubo e do preço de venda. Isso justifica a grande expansão e domínio exercido pelo capital mercantil sobre inúmeros territórios, nos quais se inserem as Américas de forma geral. O período de ascensão do Capital Mercantil coincide para Marx, com a chamada Acumulação Primitiva de Capital, elemento central para o florescimento futuro do Capitalismo Industrial. A colonização das Américas se insere nesse ciclo de domínio e saque para a geração de lucro mercantil, o autor expressa isso na seguinte passagem: 
"As descobertas de ouro e de prata na América, o extermínio, a escravização das populações indígenas, forçadas a trabalhar no interior das minas, o início da conquista e pilhagem das Índias Orientais e a transformação da África num vasto campo de caçada lucrativa são os acontecimentos que marcam os albores da era da produção capitalista. Esses processos idílicos são fatores fundamentais da acumulação primitiva." (MARX, 2013. p.872)

O segundo elemento importante é a forma de inserção desses territórios dominados no mercado mundial. Já foi afirmado anteriormente que os povos originários tiveram sua forma de organização da produção e de vida derrotados pelo modo de produção europeu. $\mathrm{O}$ roubo e o saque das comunidades originárias para a comercialização de mercadorias na Europa, logo consolidou-se como invasão e apropriação do território.

Na invasão de nosso território a lógica implantada foi a organização da produção e a apropriação dos bens da natureza sob a hegemonia das leis do capitalismo mercantil. Em um primeiro momento, os colonizadores buscavam ouro, prata e outros minérios que pudessem rapidamente ser enviados à metrópole europeia, mas posteriormente migraram para a produção e o cultivo de produtos tropicais. Stédile afirma que os colonizadores:

“(...) logo perceberam que a grande vantagem comparativa de nosso território era a fertilidade das terras e o seu potencial para cultivos tropicais de produtos que até então os comerciantes buscavam na distante Ásia ou na África.” (STÉDILE, 2005. p. 20)

Os produtos agrícolas tropicais como a cana-de-açúcar, o algodão, o café e a pimenta-do-reino, antes comprados na Ásia, poderiam ser produzidos nas terras tomadas pelos colonizadores na América, diminuindo os custos de obtenção dessas mercadorias e a distância da Europa, aumentando exponencialmente os lucros dos capitalistas mercantis.

Essa produção e a apropriação do território necessária para o seu desenvolvimento seguiu uma lógica centralizada no mercado europeu, ou seja, desde a colonização, a característica predominante da produção e da apropriação da terra no Brasil esteve vinculada a sua inserção subordinada no mercado mundial. Esse modelo de produção desenvolvido nas colônias e subordinado à hegemonia do capital mercantil 
europeu caracteriza-se como um modelo agroexportador. Stédile faz coro afirmando que:

"Tal modelo de produção, sob a égide das leis do
capitalismo, produzindo apenas produtos agrícolas e
minerais para o abastecimento do mercado europeu, foi
denominado pelos nossos historiadores de modelo
agroexportador." (STÉDILE, 2005. p. 20)

A característica de inserção subordinada ao mercado mundial, e de organização da sua produção para o mercado europeu, confirma-se inicialmente pelo pacto colonial e posteriormente pela incapacidade de promover um desenvolvimento autônomo no País, que será tratado nos próximos capítulos. Ressaltando a importância dessa característica, que se evidencia até os dias atuais. Importa citar que as primeiras estatísticas macroeconômicas organizadas pelo Banco do Brasil no século 19, segundo Stédile, afirmavam que o Brasil exportava mais de $80 \%$ de sua produção.

Partindo desses dois elementos fundamentais, a busca das maiores taxas possíveis de lucro mercantil e, a apropriação do território para a produção de produtos voltados ao mercado europeu, os colonizadores desenvolveram inúmeras formas de organizar a produção, porém a que mais se adequou foi a plantation. A plantation foi a forma predominante de organização da produção nas colônias de exploração. Após um grande debate em torno do caráter do campo brasileiro, historiadores franceses e ingleses sintetizaram o que caracterizaria a plantation e Jacob Gorender trouxe ao debate da realidade brasileira esses elementos, caracterizando-se hoje como um consenso no estudo da Questão Agrária no Brasil.

A plantation caracterizava-se basicamente pela organização da produção baseada em grandes extensões de terra, produzindo monoculturas para exportação através do emprego de tecnologias avançadas, mão-de-obra escrava e um processamento mínimo dos produtos afim de prepará-los para a exportação. Stédile com base em Gorender assim caracteriza a plantation:

"É a forma de organizar a produção agrícola em grandes fazendas de área contínua, praticando a monocultura, ou seja, especializando-se num único produto, destinando-o à exportação, seja ele a cana-de-açúcar, o cacau, o algodão, gado etc., e utilizando mão-de-obra escrava. Produzindo apenas para o mercado externo, sua localização deveria estar próxima dos portos, para diminuir custos com transporte. Essas unidades de 
produção adotavam modernas técnicas, ou seja, apesar de utilizarem força de trabalho da mão-de-obra escrava, do ponto de vista dos meios de produção, das técnicas de produção, os europeus adotaram o que havia de mais avançado." (STÉDILE, 2005. p. 21)

Para garantir a implantação da produção através da plantation foi necessário desenvolver uma forma de apropriação do território que, por um lado, garantisse a hegemonia da coroa portuguesa sobre a colônia e, por outro, gerasse garantias e estímulo aos capitalistas para investirem seu capital na produção de mercadorias para exportação. Assim, os portugueses implantaram o monopólio da propriedade da terra pela Coroa, reafirmando ainda os poderes políticos, econômicos e militares das estruturas monárquicas e feudais, porém adotando uma forma de concessão de uso vitalícia e hereditária aos capitalistas-colonizadores, afirmando um poder crescente da burguesia em formação. Essa contradição de poderes só será encerrada com a derrocada final do regime feudal na Europa e a adoção de relações capitalistas de produção e apropriação da terra no Brasil, por força e hegemonia do Capitalismo Industrial Inglês.

Sobre essa contradição na definição de um formato de apropriação da terra, coadunando com o exposto, Stédile afirma que " a forma adotada pelos europeus foi a do monopólio da propriedade de todo o território pela Monarquia, pela Coroa”, mas para implantar o modelo agroexportador e contar com os investimentos dos capitalistas comerciais "a Coroa optou pela concessão de uso com direito à herança”. (STÉDILE, 2005. p. 21)

Dessa forma, prossegue o autor, "a Coroa entrega, a capitalistas-colonizadores que dispunham de capital, enormes extensões de terra”, porém essas terras só eram concedidas com o atendimento de um critério fundamental: " $a$ disponibilidade de capital e o compromisso de produzir na colônia mercadorias a serem exportadas para o mercado europeu." (STÉDILE, 2005. p. 22)

Como elementos fundamentais para a abordagem proposta, do período de hegemonia do Capital Mercantil na organização do agrário brasileiro, reforça-se especialmente:

a) O surgimento da grande propriedade de terras (ainda na forma de concessão de uso e não na forma de propriedade privada capitalista);

b) A organização da produção voltada para fora e subordinada aos interesses da metrópole, elemento que terá continuidade com o desenvolvimento 
dependente e às funções ocupadas pelo Brasil no Mercado Mundial até os dias atuais;

c) A inserção do território brasileiro no Mercado Mundial já sob a hegemonia do Capital Mercantil, portanto, inserido na dinâmica mundial de desenvolvimento do Capitalismo;

d) O centro da acumulação capitalista na esfera da circulação das mercadorias, aproveitando-se de vantagens comparativas na obtenção de produtos de interesse no Mercado Mundial.

Com a ascensão do Capitalismo Industrial, tendo a Inglaterra como a principal potência, aumentam as pressões para a abolição da escravatura no Brasil. Se intensifica a partir de 1800 um processo de crise do trabalho escravo, devido à, entre outros elementos, o aumento das fugas e da resistência dos quilombos internamente, pois o fim da escravidão:

"Foi sendo conquistado pelos próprios trabalhadores escravizados, que fugiam e organizavam seus quilombos ou migravam para as regiões inacessíveis à parte "nobre" da sociedade, que vivia nas cidades." (STÉDILE, 2005. p. 284)

$\mathrm{E}$, às pressões para a adoção de formas de exploração do trabalho estritamente capitalistas das potências externas, o trabalho assalariado. Nesse sentido, no ano de 1850, "a Inglaterra, já sobre a égide da burguesia industrial, expansionista, impôs a proibição do tráfico de trabalhadores escravizados da África”. (STÉDILE, 2005. p. 284)

Para a elite abolir os trabalhadores negros da condição de escravos era necessário, por um lado, garantir uma força de trabalho substituta ou mantê-los numa condição subordinada que os obrigasse a continuar trabalhando nas fazendas e, por outro, evitar que ao disporem livremente de sua vida conformassem uma classe social autônoma econômica e politicamente. Nesse sentido a Coroa promulgou em 1850 a primeira Lei de Terras do Brasil, a Lei $n^{\circ} 601$ de 1850. A lei de terras de 1850 é considerada a preparação jurídica, por parte da Coroa, para garantir as condicionantes citadas anteriormente, ou seja, ao impedir o acesso dos negros libertos à terra, que os forçava a continuarem nas fazendas agora como assalariados precarizados. Stédile à esse respeito descreve que:

"Em 1850, a Coroa, sofrendo pressões inglesas para substituir a mão-de-obra escrava pelo trabalho assalariado, com a consequente e inevitável abolição da escravidão, e para impedir que, com a futura abolição, os então trabalhadores ex-escravos se apossassem das terras, promulga, em 1850, a primeira lei de terras do país. Essa lei foi um marco jurídico para a adequação do sistema econômico e de preparação para a crise do trabalho escravo, que já se ampliava.” (STÉDILE, 2005. p. 22) 
A perda da hegemonia do Capital Mercantil a nível mundial vai confirmando-se pela ascensão das potências industriais europeias e o modelo agroexportador entra numa profunda crise. Porém a crise não gera um novo modelo no curto prazo. O modelo agroexportador da plantation, utilizado nos 4 séculos de colonialismo, só vai ser completamente superado por volta dos anos 30 do século XX. 


\subsection{Crise do Modelo Agroexportador - Hegemonia do Capital Industrial}

Pode-se afirmar que, a lei de Terras de 1850 que inaugura a propriedade privada de terra no Brasil e, posteriormente, a Lei Áurea de 1888 que abre as portas ao trabalho assalariado, decretam, o fim do modelo agroexportador. Além desses elementos internos, o advento da I Guerra Mundial e as dificuldades no comércio com a Europa dela decorrente aprofundam a crise e o fim desse modelo. Stédile afirma que: " $O$ modelo plantation chega ao fim com a abolição do trabalho escravo." E sobre a importância da interrupção do comércio com a Europa o autor acrescenta: "A ultima pá de cal sobre o modelo agroexportador foi a eclosão da I Guerra Mundial, de 19141918, que interrompeu o comércio entre as Américas e a Europa. (STÉDILE, 2005. p. 25)

Sobre esses elementos é importante destacar que fazem parte de um período de transição de modelos de produção no agrário brasileiro. Essa transição é a expressão direta da mudança de qualidade entre os Capitais que à determinam, ou seja, qual a característica do Capital predominante na organização do sistema. Se o modelo agroexportador da plantation foi a forma de organização da produção do Capital Mercantil nas colônias, o novo modelo deve, necessariamente, ser a expressão da hegemonia do Capital Industrial na organização da produção agrícola em países da periferia do sistema capitalista mundial.

Stédile, apresentando a importância da Lei de Terras, nos trás a afirmação temporal desse período de crise e transição, o período que se abre com tal lei e se finda com a revolução de 1930 e a ascensão da burguesia industrial ao poder político nacional. $\mathrm{O}$ autor discorre que:

"O marco jurídico-institucional que preparou a transição do modelo agroexportador, em crise, para um novo modelo econômico, que acabaria se consolidando apenas com a "revolução" de 1930, foi a Lei de Terras de 1850." (STÉDILE, 2005. p. 283)

Conforme apresentado anteriormente esse período, de crise do modelo agroexportador e de transição para um modelo de produção e de apropriação do território organizado sob a égide do Capital Industrial, foi marcado por mudanças de algumas características fundamentais, pela manutenção de outras e pelo desenvolvimento de novos elementos no que tange a organização da produção no agrário brasileiro e na apropriação do território.

Os dois elementos centrais que sofreram mudanças nessa transição foram o da propriedade da terra e o da fonte e forma de exploração da mão-de-obra.

No que tange a propriedade da terra que era exclusiva da Monarquia Portuguesa e Brasileira, não sendo caracterizada como mercadoria, ou mesmo um ativo econômico disponível para a circulação de Capital, houve uma elementar mudança de qualidade. A partir da Lei de Terras foi normatizado no Brasil a propriedade privada da terra e a 
consolidação desta como uma mercadoria negociável, em um ativo econômico disponível à circulação do Capital através do mercado. Assim, "a lei proporciona fundamento jurídico à transformação da terra em mercadoria, em objeto de negócio, passando, portanto, a partir de então, a ter preço. (STÉDILE, 2005. p. 23)

O que fundamenta o preço da terra? O economista Guilherme Costa Delgado, citando Marx e Keynes afirma que ele "é definido pela soma capitalizada pelas rendas antecipadas”. (DELGADO, 2012. p. 48)

Para a compreensão da afirmação feita por Delgado é necessário balizarmos o conceito de renda da terra. Retomando o afirmado por Zavaski:

"A discussão da Renda Fundiária ou Renda da Terra é
um debate clássico, tendo em Quesnay, Ricardo e Smith
suas primeiras referências na economia política clássica.
Nosso referencial é a formulação de Marx desenvolvida
com base e crítica aos demais autores." (ZAVASKI,
2011. p. 11)

Assim, nas palavras de Marx, "a renda fundiária é a forma em que se realiza economicamente, se valoriza a propriedade fundiária”. (MARX, 2008. p. 829)

Para o desenvolvimento do capitalismo no Brasil, agora sobre a hegemonia do Capital Industrial, foi necessário a privatização da terra e a formação da moderna propriedade privada capitalista no campo. Porém, como a transição realizou-se sem ruptura a nova condição,

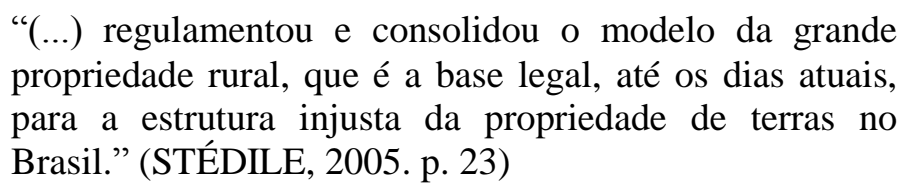

A outra mudança fundamental desse período de transição foi o fim do trabalho escravo como predominante na exploração agrícola e o surgimento do trabalho assalariado. Stédile, citando Ribeiro, afirma que por ocasião da libertação dos escravos cerca de dois milhões de ex-escravos adultos deixaram as fazendas e o trabalho agrícola dirigindo-se para as cidades. Para resolver o problema de falta de mão-de-obra no campo brasileiro a forma adotada foi a importação de mão-de-obra europeia.

O desenvolvimento do capitalismo industrial na Europa e o fim do sistema de vassalagem característico do Modo de Produção Feudal havia excluído da terra milhares de camponeses que foram impulsionados para as cidades. Marx expondo sobre a expropriação dos camponeses na Inglaterra afirma que:

"Com a dissolução das vassalagens feudais, é lançada ao mercado de trabalho uma massa de proletários, de indivíduos sem direitos, que por toda parte enchiam inutilmente os solares." (MARX, 2013. p. 839) 
Intensificando esse processo, "o grande senhor feudal criou um proletariado incomparavelmente maior, usurpando as terras comuns e expulsando os camponeses das terras" (MARX, 2013. p. 839), isso dado o "florescimento da manufatura da lã, com a elevação consequente dos preços da lã", confirmando a sua ligação direta com o desenvolvimento do Capitalismo Industrial.

Foi esse campesinato proletarizado produzido pelo desenvolvimento do Capitalismo Industrial na Europa o escolhido para substituir os escravos na grandes fazendas brasileiras. A elite brasileira realizou nesse período uma campanha sistemática na Europa para atrair esse contingente de trabalhadores para o país. Vejamos a afirmação de Stédile:

\begin{abstract}
"Para resolver o problema (da falta de mão-de-obra no campo causada pelo fim da escravidão), a coroa foi à Europa em busca da mão-de-obra dos camponeses europeus pobres. Através de intensa propaganda, procurou convencê-los a emigrar para o Brasil para trabalharem na agricultura." (STÉDILE, 2005. p. 295)
\end{abstract}

Nas estatísticas apresentadas por Ribeiro, de 1851 à 1930 chegaram ao Brasil 3 milhões 712 mil trabalhadores europeus pobres. (RIBEIRO, 2006, p. 222) Se observarmos apenas no período de 1886 à 1915 esse número chega a pouco mais de 2,3 milhões de imigrantes, em sua maioria formado por casais jovens. Esse número praticamente coincide com o número de trabalhadores escravizados juridicamente libertos pela Lei Áurea de 1888. Assim confirmamos o já apresentado anteriormente, a importação de mão-de-obra dos camponeses europeus pobres, excluídos pelo desenvolvimento do Capitalismo Industrial no centro do sistema, foi a forma de superar a crise do fim do trabalho escravo e desenvolver a exploração capitalista na periferia.

A forma de organização da produção predominante nas grandes propriedades que substituíram a mão-de-obra escrava pela mão-de-obra formada pelos imigrantes foi denominada pelos sociólogos como colonato. Especificamente nas lavouras de café, Stédile assim descreve o colonato:

"Por esse sistema, os colonos recebiam a lavoura de café
pronta, formada anteriormente pelo trabalho escravo,
recebiam uma casa para moradia e o direito de usar uma
área de aproximadamente dois hectares por família, para
o cultivo de produtos de subsistência, e de criar pequenos
animais logrando, assim, melhores condições de
sobrevivência." (STÉDILE, 2005. p. 25)

Nesse formato, as famílias de colonos eram obrigados por contrato a cuidarem de um número determinado de pés de café e, pelo trabalho realizado, recebiam em produto ao final da colheita. Essa forma especifica de exploração foi o caldo necessário para que vários intelectuais, entre eles Alberto Passos Guimarães, afirmassem que:

"No sistema de plantação, como aliás no conjunto de economia pré-capitalista do Brasil-Colônia, o elemento 
fundamental, a característica dominante à qual estavam subordinadas todas as demais relações econômicas, é a propriedade agrária feudal, sendo a terra o principal e mais importante dos meios de produção." (GUIMARÃES in STEDILE, 2005. p. 45)

É importante nesse ponto ressaltar que a afirmação aqui apresentada é a de que a Questão Agrária brasileira desenvolvida após a invasão deste território pelas potências europeias sempre esteve subordinada ao Modo de Produção Capitalista. Assim afirmase, com base nos autores citados anteriormente, que a plantation foi uma forma de organizar a produção de mercadorias nas colônias desenvolvida pelo Capital Mercantil, com uma de suas bases calcada no trabalho escravo, mas que, não se configura como um Modo de Produção Escravista. Da mesma forma, o colonato, desenvolvido no período de crise do modelo agroexportador e ascensão do Capital Industrial, com base no trabalho do colono semelhante às relações servis, também não se configura como um Modo de Produção Feudal.

As formas especificas de exploração desenvolvidas pelo Capital no campo brasileiro seguem, os interesses e tendências do desenvolvimento do capitalismo mundial, apresentando porém, características próprias derivadas da sua formação econômica-social periférica no sistema. Para tal afirmação Bambirra explicita que:

“(...) a América Latina esteve, desde a Conquista,
vinculada à expansão e ao transcurso da consolidação do
capitalismo mundial - sob suas formas comercial e
industrial - como área periférica, subordinada e
dependente.” (BAMBIRRA, 2012. p. 79)

Como já apresentado anteriormente o marco final desse período é o ano de 1930, porém apenas como marco temporal, pois o processo de alteração no poder político e, das estruturas de organização da produção agrícola e apropriação do território já vem construindo-se desde o final do século XIX.

Como elemento marcante do ano de 1930, que simboliza a passagem do poder da oligarquia rural para a burguesia industrial nascente está a "revolução" que leva Getúlio Vargas ao poder. Stédile afirma que:

“(..), setores das elites da nascente burguesia industrial dão um golpe, fazem uma "revolução" política por cima, tomam o poder da oligarquia rural exportadora e impõem um novo modelo econômico para o país." (STÉDILE, 2005. p. 28)

A burguesia industrial, embora ainda pequena em número, pode se impor aproveitando as contradições acumuladas entre as oligarquias rurais e amplos setores da sociedade brasileira. Conforme Bambirra isso se deu devido:

“(...) a burguesia industrial - classe que se desenvolvia paulatinamente, impulsionada por condições favoráveis geradas pelo conflito bélico de 1914-1918 e, 
posteriormente, pela crise do capitalismo mundial - fosse a única classe com a condição de aproveitar os antagonismos existentes entre as oligarquias e todos aqueles setores e classes, para se impor frente às oligarquias e reivindicar para si uma participação preponderante no controle do poder." (BAMBIRRA, 2012. p. 89)

A autora acrescenta ainda, a respeito da burguesia industrial, que:

“(..), objetivamente, era ela a única classe que de fato representava os interesses do desenvolvimento e sobrevivência do sistema de dominação em seu conjunto, por se situar em seu nível mais importante; ou seja, a dinâmica das contradições econômico-sociais engendradas no seio do sistema oligárquico conduzia, de forma irreversível, à consolidação do poder burguês." (BAMBIRRA, 2012.p. 89)

A burguesia industrial brasileira desenvolveu, conforme afirma o grande sociólogo Florestan Fernandes, o modelo de industrialização dependente. Segundo Stédile, devido ao "fato de a industrialização ser realizada sem rompimento com a dependência econômica aos países centrais" (STÉDILE, 2005. p. 28). Aí reside um dos elementos que se mantiveram como características do agrário brasileiro, mesmo com a mudança da hegemonia do Capital Mercantil para o Capital Industrial.

A subordinação ao centro do capitalismo e a determinação da forma de apropriação do território e de organização da produção agrícola pela condição de dependência, ou seja, se a metrópole colonizadora determinou a forma de exploração na colônia agora o centro capitalista determina a forma de exploração no país dependente. Para Bambirra:

"É assim que o curso do desenvolvimento do capitalismo na América Latina passa de uma formação socioeconômica dependente colonial-exportadora para uma formação socioeconômica dependente capitalistaexportadora, até finalmente chegar à uma formação socioeconômica dependente capitalista-industrial." (BAMBIRRA, 2012.p. 79)

Outro elemento fundamental que se manteve na transição foi o poder da oligarquia rural, ou seja, mesmo a burguesia industrial assumindo a hegemonia no país manteve dentro de seu bloco histórico ${ }^{1}$ a oligarquia rural.

Bambirra e Stédile apresentam um conjunto de motivos para essa superação sem superação, essa mudança sem mudança. Stédile justifica essa aliança:

\footnotetext{
${ }^{1}$ Adota-se aqui o conceito apresentado por Gramsci e discutido por Portelli em sua obra: Gramsci e o Bloco Histórico, assim, a classe burguesa industrial é o núcleo do bloco histórico desempenhando a sua função hegemônica porém, outras classes compõem a estrutura e a superestrutura de poder compondo a direção política e moral da sociedade. (PORTELLI, 1977.)
} 
"Primeiro, porque a burguesia industrial brasileira tem origem na oligarquia rural, da acumulação das exportações de café e do açúcar, ao contrário dos processos históricos da formação do capitalismo na Europa e nos Estados Unidos.” (STÉDILE, 2005. p. 28)

Coadunando com essa afirmativa Bambirra reforça que:

“ (...) o surgimento dos empresários industriais é produto da simbiose da oligarquia (latifundiária, mineradora ou comercial exportadora) com setores industriais." (BAMBIRRA, 2012. p. 80)

Assim, os dois autores citados reforçam a ideia de que a oligarquia rural está na gênese do capitalista industrial brasileiro e, esse é um dos elementos que impede o rompimento total entre essas duas classes distintas e que, podem estar representadas pelo mesmo indivíduo.

Outro elemento dessa simbiose estabelecida entre oligarquia e burguesia industrial que concordam os autores citados acima é a necessidade, por parte dos empresários industriais de se utilizarem dos capitais acumulados pela oligarquia agrárioexportadora. Bambirra afirma que essas duas classes estabelecem uma relação de íntima interdependência, dessa forma:

"Tal interdependência se reflete de forma muito nítida na medida em que os capitais gerados no setor exportador são transferidos ao setor industrial e possibilitam sua expansão.” (BAMBIRRA, 2012. p. 79)

Stédile é mais explicativo em sua descrição afirmando que:

“(...): o modelo industrial, como era dependente, precisava importar máquinas, e até operários, da Europa e dos Estados Unidos. E a importação dessas máquinas só era possível pela continuidade das exportações agrícolas, que geravam divisas para seu pagamento, fechando o ciclo da lógica da necessidade do capitalismo dependente." (STÉDILE, 2005. p. 28)

Nesse momento é importante ainda trazer a luz um elemento novo, que surge no período de crise do modelo agroexportador, o surgimento do campesinato como classe e a apropriação de porções de terras por ela.

A solução encontrada para a substituição da mão-de-obra escravizada pela importação de colonos europeus promoveu uma das vertentes de desenvolvimento do campesinato brasileiro. Uma parte considerável dos colonos, que não foram destinados às lavouras dos grandes latifundiários foi para o Sul do Brasil, aliciados por Companhias Colonizadoras receberam lotes de em média 30 hectares, pelos quais deveriam pagar. Stédile clareia bem essa questão afirmando que: "Parte dos migrantes foi para o Sul do país, pela maior disponibilidade de terras e pelo clima, "recebendo" 
lotes de 25 a 50 hectares,..." . O autor ainda reforça a entrada direta dessas terras na lógica do mercado, e mesmo da produção realizada nela:

"Todos os camponeses colonos que "receberam" terras no Sul tiveram de pagar por elas e isso os obrigou a se integrarem imediatamente na produção para o mercado." (STÉDILE, 2005. p. 25)

A outra vertente de formação do campesinato brasileiro foi a originária do processo de miscigenação ocorrido em todo o período colonial e que prosseguiu de maneira contínua até a década de 1930. As populações mestiças que se formaram e que não se submetiam ao trabalho escravo, mas que não poderiam tornar-se capitalistascolonizadores, bem como os escravos fugidos foram migrando rumo ao interior do país. Essas populações ocuparam boa parte do território brasileiro e se dedicavam à uma agricultura de subsistência criando comunidades mais ou menos autônomas. Esses negros, mestiços, trabalhadores pobres:

"Não tinham a propriedade privada da terra, mas a ocupavam, de forma individual ou coletiva, provocando, assim, o surgimento do camponês brasileiro e de suas comunidades." (STÉDILE, 2005. p. 27)

O embrenhamento no sertão rendeu à essa vertente do campesinato brasileiro o nome de sertanejo. Essas comunidades diferenciaram-se por sua origem e relação com o meio ambiente ao qual se estabeleceram e são atualmente reconhecidas como Comunidades Tradicionais, além dos Quilombos. Porém a grande maioria foi excluída da terra com a chegada do Capital aos rincões do Brasil através da expansão da fronteira agrícola.

Afirma-se aqui, que além da apropriação privada da terra pelos grandes capitalistas e a criação do latifúndio na história do Brasil, esse período, contraditória e complementarmente criou uma classe de camponeses possuidores de terras, que se apropriaram, seja na forma capitalista adquirindo terras, seja na forma de posse se embrenhando nos sertões. Essa classe social, heterogênea por formação, juntamente com os povos indígenas remanescentes assumiram a frente de batalha principal na luta de classes no campo brasileiro, na disputa pela terra e pelo território.

Na Questão Agrária, explicitada até aqui, observando-se os dois aspectos que reforçamos serem os fundamentais, a forma de organização da produção adotada pelo Capital em cada um de seus estágios distintos de desenvolvimento e, a forma de apropriação da terra desenvolvida, aponta-se que esse período caracterizou-se pela privatização da terra, pela modernização da produção, pelo surgimento do campesinato e pela determinação e subordinação da agricultura ao modelo industrial. Sobre esses aspectos duas passagens de Stédile são claras e autoexplicativas, afirma o autor que "esse período se caracteriza pela subordinação econômica e política da agricultura à indústria” (STÉDILE, 2005. p. 28). Posteriormente, quase que concluindo a afirmação feita até aqui dos elementos que persistiram na Questão Agrária brasileira mesmo com a 
mudança de hegemonia do Capital Mercantil para o Capital Industrial e, dos elementos novos que contribuem na caracterização desse novo momento o autor prossegue clareando que:

"Foi um processo de modernização capitalista da grande propriedade rural e, em relação ao surgimento dos camponeses, é o período histórico em que eles são induzidos a se vincularem totalmente às regras do mercado e a se integrarem à indústria." (STÉDILE, 2005. p. 29)

A subordinação da agricultura à indústria afirmada por Stédile vai se tornando cada vez mais uma integração e o desenvolvimento de uma agricultura industrial.

Durante o período que segue, pode-se observar, derivado dos elementos já longamente expostos anteriormente, um crescente movimento de reinvindicação pelo acesso a terra. Apenas para citá-los, a dificuldade de acesso a terra pelas massas de trabalhadores libertos da escravidão e de seus descendentes, a integração da agricultura à indústria e a liberação de massas de trabalhadores rurais desempregados do trabalho agrícola e, a continuidade do monopólio da terra nas mãos da oligarquia, intensificada pelos processos econômicos de centralização e de concentração de Capital. Sobre esse aumento dos movimentos reivindicatórios o intelectual e notável quadro político do Partido Comunista Brasileiro (PCB) Clodomir Santos de Moraes, referindo-se ao período de 1945-1947 afirma que:

"O retorno do país ao regime de garantias democráticas (em 1945), interrompido pelos 10 anos da ditadura de Vargas, propiciou uma grande mobilização de massas camponesas na maioria dos Estados brasileiros." (MORAES, 1997. p. 12)

A expressão mais simbólica do auge das lutas camponesas nesse período foi a realização em 17 de novembro de 1962 do I Congresso Camponês Nacional, na cidade de Belo Horizonte, segundo Moraes tal congresso foi:

“(...) convocado e organizado pela $\mathrm{ULTAB}^{2}$, com forte apoio do governo federal, interessado em buscar a melhor forma de evitar que o movimento camponês seguisse fora da tutela governamental." (MORAES, 1997. p. 40)

O resultado final deste congresso foi a afirmação da bandeira de ordem: Reforma Agrária! Na Lei ou na Marra, embora com posições divergentes entre as diferentes organizações que compunham o Congresso. Segundo Moraes o congresso teve a participação de 1400 delegados, sendo 215 das Ligas Camponesas ${ }^{3}$, 38 delegados

\footnotetext{
${ }^{2}$ A União dos Lavradores e Trabalhadores Agrícolas do Brasil (Ultab) foi criada em São Paulo, no final do ano de 1955, pelo PCB com a finalidade de organizar os trabalhadores rurais brasileiros.

${ }^{3}$ As Ligas Camponesas foram incialmente organizadas pelo Partido Comunista Brasileiro no período de 1945 à 1947, após a proscrição do PCB as Ligas são praticamente exterminadas. As Ligas ressurgem em
} 
do Master $^{4}$ e o restante de organizações ligadas à Ultab. A posição das Ligas, embora minoritária em delegados foi a que se sobressaiu. É o que nos confirma Moraes:

"Os camponeses não queriam saber como se realizava uma reforma agrária, mas, sim, desejavam discutir a maneira de impor imediatamente a reforma agrária radical." (MORAES, 1997. p. 49)

Assim, "A bandeira da reforma agrária radical, na lei ou na marra, saída dos camponeses das Ligas, contagiou todos os delegados" afirma o autor.

A elite brasileira, para continuar seu projeto de hegemonia e exploração não poderia, de nenhuma forma possibilitar o avanço dessa bandeira, nem das demais reformas que possibilitassem algum risco ao seu domínio. Devido à isso, afirma Moraes:

"Num curto período de 7 anos, houve 6 tentativas de golpes contra o regime representativo brasileiro, com a finalidade de implantar uma ditadura reacionária. $\mathrm{O}$ primeiro foi em agosto de 1954, com a morte trágica do presidente Getúlio Vargas;" (MORAES, 1997. p. 40)

$\mathrm{O}$ autor segue apresentando as demais tentativas como a do presidente Carlos Luz evitar, em 1955, a posse do mandatário eleito; as revoltas militares em Jacareacanga e Aragarças no governo Kubitschek; a crise política artificialmente criada em abril de 1961 e o golpe realizado 4 meses depois, com a renúncia de Jânio Quadros. João Goulart assumiu o governo mas a ditadura militar só era uma questão de tempo. O golpe realizado em abril de 1964 e a repressão que se seguiu a ele possibilitou a continuidade do projeto do Capital para o campo brasileiro sem nenhuma alteração da estrutura de apropriação da terra.

Para avançar na afirmação da subordinação, da organização da produção na agricultura e, da apropriação do território, agora sob a hegemonia do Capital Industrial aliado às oligarquias rurais e dependente dos Centros Capitalistas, utilizamos a afirmação de Delgado:

"O período histórico que estamos considerando, 19651985, constitui com muito maior clareza a etapa do desenvolvimento de uma agricultura capitalista em processo de integração com a economia urbana e industrial e com o setor externo." (DELGADO, 2012. p.13)

Esse período caracterizou-se como o auge da modernização conservadora, nome esse já justificado nos elementos apresentados anteriormente. Se por um lado a

1954 de forma mais autônoma e sob forte influência de Francisco Julião, filiado ao Partido Socialista Brasileiro (PSB).

${ }^{4}$ Reproduzimos aqui a descrição de Moraes: "Master (Movimento de Agricultores Sem Terra) foi uma organização notoriamente oficialista, criada pelo governador Brizola para impedir que, no Rio Grande do Sul, os trabalhadores rurais se filiassem à Ultab ou às Ligas." (MORAES, 1997. p. 37) 
agricultura se modernizou tecnologicamente, conservou a estrutura centralizada e excludente da apropriação da terra. Delgado afirma que "a chamada modernização conservadora da agricultura nasceu com a derrota do movimento pela reforma agrária”. (DELGADO, 2012. p.13)

O auge da modernização conservadora só foi possível graças ao golpe e a utilização total e irrestrita do Estado para a sua implantação. Gorender, em sua obra intitulada "A Ditadura do Grande Capital", além de retirar o manto nacionalista da ditadura brasileira ainda traz a fundamentação teórica de como o aparelho de estado brasileiro foi um elemento central na acumulação capitalista e no desenvolvimento da dependência nesse período, subordinado aos interesses do empresariado e do capital internacional.

O que importa aqui é trazer os elementos que sedimentaram a integração agricultura-indústria, apresentando o papel do Estado Ditatorial e que, criaram as condições para um nova hegemonia no agrário brasileiro, a hegemonia do Capital Financeiro, que será apresentada mais à frente.

A integração da agricultura à indústria, elemento fundamental para a afirmação de que o Capital Industrial tornou-se determinante nas relações do agrário brasileiro, dáse de duas formas, ou melhor, em duas direções.

Numa primeira direção, transformando a agricultura num grande mercado consumidor das indústrias, incentivando a adoção de pacotes tecnológicos baseados na mecanização e utilização de insumos químicos sintéticos. Delgado utilizando-se de dados de tratorização (utilização de tratores na agricultura) e no consumo de fertilizantes afirma que "foi na década de 1970 que houve uma intensificação do consumo industrial pela agricultura" (DELGADO, 2012. p.16), o autor prossegue afirmando que nesse período a frota de tratores foi triplicada.

Em outra direção, o desenvolvimento da indústria de processamento de produtos agrícolas foi o outro elemento de integração. No modelo agroexportador os grandes latifundiários realizavam um beneficiamento mínimo dentro das próprias fazendas, preparando os produtos para a exportação e, criando uma certa "indústria" subordinada a agricultura. Afirmo aqui a subordinação da "indústria" à agricultura pois, sendo essa a definidora dos elementos centrais e a outra apenas com uma função assessória no complexo agroexportador, é quem determina o processo. Agora, com a mudança da hegemonia a determinação é inversa e aprofunda a integração técnica e econômica da agricultura à indústria. Segundo Delgado:

“(...), o processo de integração técnica agriculturaindústria foi ainda fortemente impulsionado pela modernização da indústria processadora de produtos rurais, a qual em interação com o setor produtivo agrícola, a indústria de bens de capital e os serviços de apoio constituem verdadeiros complexos ou "sistemas agroindustriais" interligados.” (DELGADO, 2012. p.13) 
O autor, além de afirmar a direção de integração através da indústria de processamento de produtos agrícolas ainda concluí apresentado que todo esse arranjo configura-se como um complexo agroindustrial, como outrora configurou-se $\mathrm{o}$ complexo agroexportador.

É importante compreender aqui qual o papel do Estado brasileiro nesse processo. Já foi apresentado anteriormente a característica ditatorial, empresarial e subordinada ao grande capital desse estado. Duas linhas de ações foram implementadas pelo Estado para garantir a integração da agricultura à indústria.

A primeira linha de ação compreendeu um conjunto de políticas agrícolas vinculadas à implantação dos pacotes tecnológicos e à redução dos riscos de produção agrícola. Delgado destaca nesse período, a criação da Embrater (Empresa Brasileira de Assistência Técnica e Extensão Rural), da Embrapa (Empresa Brasileira de Pesquisa Agropecuária), da Política de Garantia de Preços Mínimos (PGPM) e do Sistema Nacional de Crédito Rural (SNCR), assim afirma que "o governo federal iria, na verdade, estruturar um chamado setor público rural, de caráter gigante” (DELGADO, 2012. p.15). Essa política estatal de garantias e incentivos impulsionava os fazendeiros a se modernizarem. Delgado, à respeito da política agrícola desse período afirma:

"Esta induzia a produção de mercadorias setoriais por intermédio dos incentivos fiscais e financeiros protetores das margens de lucro dos fazendeiros que alteravam a sua base técnica; e também a valorização patrimonial dos que ampliavam a fronteira de terras apropriadas para fins produtivos ou especulativos." (DELGADO, 2012. p.14)

Assim, além do incentivo da mudança tecnológica que levou os latifundiários à tornarem-se os novos fazendeiros tecnificados, conforme o autor nos afirma acima, também levou uma expansão da fronteira agrícola interior adentro. Já afirmamos anteriormente que, uma das vertentes de formação do campesinato brasileiro, foi a ocupação, na forma de posse, dos sertões pelos trabalhadores pobres negros e mestiços. Com os incentivos governamentais os fazendeiros avançam sobre essas terras empurrando ainda mais os trabalhadores para os sertões.

Aqui é importante ressaltar que a lógica de exclusão do acesso a terra pelos trabalhadores, obtida pela Lei de Terras de 1850, e intensificada pela integração agricultura-indústria provocou uma forte migração dos trabalhadores e que, as fronteiras nacionais não foram instransponíveis para seus sonhos de vida melhor. Para esse estudo, importará as relações do processo de desenvolvimento do Capital no agrário brasileiro e sua influência direta no Paraguai. Ao longo das décadas de 1950 até 1970 formou-se uma população de mais de 350 mil camponeses brasileiros vivendo em terras paraguaias. O jornalista Carlos Wagner apresenta em 1989 que:

"O governo do Brasil estima que existam 350 mil camponeses vivendo lá, dos quais $33 \%$ são gaúchos. Isto representa $10 \%$ da população daquela nação (3.500.000)." (WAGNER, 1990. p. 13) 
Esse período não apenas coincide com a entrada em massa de agricultores brasileiros no Paraguai, mas essa se dá exatamente pela expulsão de camponeses das terras no Brasil, tema que será tratado mais a frente.

$\mathrm{Na}$ outra linha de ações do Estado brasileiro para integrar a agricultura à indústria estão as políticas de crédito público. Durante esse período o crédito rural desempenhou uma importante função. Para incentivar a adoção de pacotes tecnológicos modernizantes o Estado vinculou à eles a liberação de créditos e outros mecanismos da política financeira como os seguros agrícolas. Delgado apresentando o papel do Estado no incentivo à integração agricultura-indústria apresenta que:

\begin{abstract}
"Estimulou-se a adoção de pacotes tecnológicos da "Revolução Verde", então considerados sinônimos de modernidade, e incentivou-se um enorme aprofundamento das relações de crédito na agricultura, mediando a adoção desses pacotes com mecanismos de seguro de preço e seguro do crédito à produção." (DELGADO, 2012. p.13)
\end{abstract}

Esse autor é enfático ao afirmar:

“(...) que a expansão do crédito rural e agroindustrial dos anos de 1970 propiciou condições para a articulação das relações técnicas agricultura-indústria num patamar de alta densidade.” (DELGADO, 2012. p.116)

As transformações ocorridas no agrário brasileiro, que são subordinadas e determinadas pela mudança de qualidade do Capital que às impõem, foram a expressão da mudança da hegemonia do Capital Mercantil e seu modelo de exploração agroexportador para a hegemonia do Capital Industrial e seu modelo da modernização conservadora.

A maturidade do modelo hegemônico exercida pelo Capital Industrial, nas palavras de Delgado, "de fato ocorreu principalmente no período de 1965 a 1980, caracterizado como auge da modernização conservadora" (DELGADO, 2012. p.19) 


\subsection{Crise do Modelo da Modernização Conservadora - A Hegemonia do Capital Financeiro}

Se o período de 1850 à 1930, já apresentado anteriormente, foi uma sorte de crise do modelo agroexportador e de transição à hegemonia do Capital Industrial e consolidação de seu modelo da modernização conservadora, serão as décadas de 1980 e 1990 o seu homônimo na crise do modelo da modernização conservadora e a transição para a hegemonia do Capital Financeiro na agricultura. Para Delgado:

"Os meados dos anos de 1980 e os anos 1990 são
demarcados por fatos significativos e políticas
conjunturais, atuantes no sentido de desmontar o projeto
de modernização conservadora da era militar, sem,
contudo estruturar condições econômicas e políticas para
constituir uma nova estratégia de acumulação de capital
na agricultura." (DELGADO, 2012. p.77)

O primeiro elemento conjuntural apresentado pelo autor é a Crise cambial de 1982. Diante a crise, as medidas de ajustamento econômico adotada pelo governo, sustenta Delgado, "irão configurar no campo econômico uma espécie de embrião do apelo à exportação de commodities" (DELGADO, 2012. p.77), elemento que se configurará como uma característica do novo modelo, ou seja, um elemento contínuo da organização da produção no agrário brasileiro, a destinação para o mercado externo.

Dois elementos são fundamentais no processo de "desmonte" modernização conservadora.

O primeiro deles é a Constituição de 1988 e a correlação de forças que se estabelece no processo da Constituinte, um novo assenso da luta pela terra, impulsionado pelas lutas democráticas pós-ditadura militar obrigou os setores agrários das classes dominantes, fortemente favorecidos pelas políticas do regime militar, a recuarem em suas propostas. Veremos no terceiro capitulo que esse processo coincide com o retorno de milhares de camponeses brasileiros que foram utilizados na expansão do modelo da modernização conservadora para o Paraguai, e que são expropriados pela expansão do latifúndio brasileiro naquele território. Isso tudo, resultou em uma Legislação que, nas palavras de Delgado, "alteram fortemente as condições políticas e jurídicas sob as quais se apoiaram as políticas agrícolas e agrárias do regime militar”. (DELGADO, 2012. p.77)

Outro elemento fundamental nesse período foram as reformas neoliberais dos anos de 1990. A liberalização extrema retirou as políticas de proteção à produção e abriu o mercado brasileiro ao comércio externo sem barreiras protetivas, isso obrigou os

\footnotetext{
${ }^{5}$ Utilizamos a palavra "desmonte", porém, características fundamentais do modelo da modernização conservadora serão incorporadas pelo novo modelo assim como acorreu na transição do modelo agroexportador. Não pode haver desmonte sem um rompimento de sistema, assim, toda a evolução da questão agrária dando-se dentro do Modo de Produção Capitalista, mantêm-se as características fundamentais.
} 
Capitalistas Agrários brasileiros à entrarem no mercado sem a mão amiga do Estado. Delgado afirma que as reformas neoliberais:

“(...) desmontaram importantes estruturas internas de fomento produtivo e comercial, e abriram o comércio exterior de maneira muito diferente daquela que ocorrera no período anterior." (DELGADO, 2012. p.70)

Os três elementos anteriores são fundamentais na transição de modelos, passando da modernização conservadora sob hegemonia do Capital Industrial para o agronegócio ${ }^{6}$ sob hegemonia do Capital Financeiro.

O primeiro elemento apresentado foi a Crise Cambial de 1982. Delgado afirma que:

"A partir da década de 1980 a economia brasileira se defrontará com um longo período de relativa estagnação econômica, em grande medida impostas pelas condições do ajustamento à crise do endividamento externo." (DELGADO, 2012. p.78)

O papel desempenhado pela agricultura nesse período oscilou entre dois momentos de ser fundamental para a gestão da crise da dependência externa e um momento intermediário de ficar relegada na política econômica. Delgado divide esses três momentos em: "1983-1993, primeira tentativa de resposta a crise do endividamento" o período de 1994-1999 como o período das políticas neoliberais de muita liquidez internacional, liberalização externa e de aumento do endividamento brasileiro e, "2000 até o presente, relançamento da estratégia de reprimarização do comércio externo a qualquer custo”. (DELGADO, 2012. p.79)

O que esse período afirmou na organização da produção agrícola e na apropriação de territórios no Brasil? Como resposta à crise recessiva que o Brasil enfrentou a partir de $1982^{7}$ o governo lançou a estratégia de geral saldos comerciais. Como a industrialização do período anterior basicamente esteve vinculada à substituição de exportação, direcionada ao mercado interno e, com forte dependência internacional, são, o setor agrícola e os complexos agroindustriais a base das exportações para geral tais saldos.

Esse processo de incentivo ao setor agrícola vinculado à exportação reforça as características já apresentadas anteriormente nos ciclos de hegemonia do Capital Mercantil e do Capital Industrial. A primeira relaciona-se a determinação externa da produção, ou seja, a característica do modelo agroexportador de organizar a produção

\footnotetext{
${ }^{6}$ Usamos aqui a conceituação de Agronegócio apresentada no Dicionário da Educação no Campo (CALDART et. all., 2012. p. 79) que em síntese o afirma como a expressão do Capital Financeiro na agricultura com as tendências de ocupar extensas áreas do país e de apresentar uma forte concentração de empresas com controle internacional.

${ }^{7}$ Delgado afirma a crise recessiva a partir de 1982 apresentando como sua causa mais direta a reversão dos fluxos de financiamento externo, após a moratória mexicana de 1982. (DELGADO, 2012. p.79)
} 
para a exportação, reafirmada no modelo da modernização conservadora é novamente mantida, reafirmada e re-significada. A busca de superávits na balança comercial através de exportações de produtos primários provoca também uma especialização ainda maior da produção, reafirmando a monocultura como uma marca permanente do agrário brasileiro.

A outra característica é a apropriação da terra com base em grandes propriedades e na expansão da fronteira agrícola para o centro-oeste brasileiro, que, como apresentado anteriormente expropriará mais terras ocupadas por comunidades camponesas que se desenvolveram nos períodos anteriores de desenvolvimento do capitalismo no campo. Delgado afirma sobre os saldos comerciais criados com base na exportação que:

"Estes estão ancorados basicamente na expansão das exportações de produtos básicos e agroprocessados, que avançam pela nova fronteira agrícola da região centrooeste." (DELGADO, 2012. p.80)

A base produtiva desenvolvida no período da modernização conservadora tornase um importante instrumento para aumentar as exportações e gerar os saldos comerciais necessários para equilibrar a relação econômica externa brasileira. Os saldos obtidos são nas palavras de autor citado acima, "cativos ao serviço da dívida ou da remuneração dos serviços do capital estrangeiro” (DELGADO, 2012. p.81)

O período que entremeia a politica baseada nas exportações primárias como instrumento de equilíbrio das contas externas brasileiras, para o ator, a mudança neoliberal de 1994-1998, baseia-se em algumas características nas políticas e decorre em alguns impactos importantes no agrário brasileiro.

Como características importantes nas quais baseiam-se as ações do Estado Neoliberal imposto e que impactam na agricultura, estão, em primeiro lugar a política de comércio exterior brasileira extremamente liberal, segundo Delgado:

“(...) ancorada no tripé câmbio desvalorizado, tarifas ultramitigadas e desregulamentação no campo das políticas de fomento agrícola e industrial." (DELGADO, 2012. p.81)

A segunda característica, já afirmada pelo autor na citação acima consistiu na desestruturação do Estado no processo de fomento a agricultura. A vitória da vertente neoliberal posteriormente a Constituição de 1988 promoveu a "desmontagem das instituições estatais gestoras do projeto de modernização conservadora" (DELGADO, 2012. p.84). Dentre as principais ações de desmonte da política agrícola realizada nesse período apresenta-se: a desmontagem final dos institutos de fomento por produto ${ }^{8}$, a

\footnotetext{
${ }^{8}$ Esses Institutos fizeram parte das políticas implementadas na Era Vargas, são exemplos o Instituto do Açúcar e Álcool (IAA), Instituto Brasileiro do Café (IBC), o Centro do Trigo Nacional do Banco do BrasilDepartamento do Trigo Nacional (CTRIN-DTRIG) da SUNAB. Esses foram extinguidos pela Lei no 8.029, de
} 
alteração da política comercial, de armazenagem e garantias operadas pela Companhia Nacional de Abastecimento (CONAB) e, a redução do volume de crédito rural concedido.

O autor que estamos recorrendo para essa fundamentação reforça o papel desse período numa crise da expansão da agricultura capitalista e de uma redução do preço da terra. Já foi apresentado anteriormente que o preço da terra é determinado pela expectativa de obtenção de lucro dessa área, com as políticas neoliberais e sua consequente ação na redução do preço das commodities agrícolas reduziu consideravelmente a renda da terra e o lucro na agricultura. Delgado afirma que:

“(...) essa década dos anos de 1990 foi período de forte implementação de acordos de comércio e de uma política cambial a partir de 1994, que combinados a minimização da intervenção estatal anteriormente praticada, promoveram nítido recuo na expansão da agricultura capitalista e forte processo de desvalorização da renda fundiária, expressa pela queda no preço da terra." (DELGADO, 2012. p.84)

É importante ressaltar que a queda do preço da terra acirra o processo de disputa pela apropriação do território e possibilita um ascenso na luta pela terra. Notadamente a década de 1990 é o período de maior expressão da luta pela terra no período recente. Que impacto tem as características expostas anteriormente para esse processo? Destacase aqui dois elementos importantes para a luta pela terra e um terceiro para a apropriação do território. O primeiro elemento é dado diretamente pela redução do preço da terra, decorrente da já citada redução da renda da terra, que facilita a sua obtenção por parte do Estado e destinação para a Reforma Agrária, que encontra-se, como pauta e como Organizações, em franca expansão pós-ditadura. O segundo elemento, é o impacto da redução da renda da terra nos pequenos agricultores, que paradoxalmente, são obrigados a deixarem as atividades produtivas e em muitos casos a se desfazerem das propriedades para quitarem créditos e dívidas bancárias. Esses camponeses, agora na condição de Sem Terras, vão aumentar a organização e a força dos movimentos de luta pela Terra.

O terceiro elemento, importante para a análise aqui proposta, é a concentração da terra que esse processo provoca. Se as taxas de lucro já não são mais atraentes para os capitalistas do campo investirem na produção, a tendência é que estes adquiram mais terras como reserva de valor, aumentando a concentração da terra no país.

Essa lacuna provocada pelo Neoliberalismo no campo brasileiro para as aspirações de acumulação capitalista da burguesia agrária findou-se com a crise econômica do final do ano de 1998. Delgado sustenta que os déficits constantes causados pela redução das exportações desencadearam um ataque especulativo externo contra o Real que entre dezembro de 1998 e janeiro de 1999 foram "suficientes para

12/04/1990 que autorizou o poder executivo a extinguir o IAA, o IBC, o BNCC, a Embrater e a fundir três empresas para formar a CONAB (CFP, COBAL e CIBRAZEM). 
esvaziar em poucos meses o volume das reservas líquidas brasileiras". O autor prossegue afirmando que esse processo frustrou "praticamente toda a possibilidade de continuidade da política econômica anterior". (DELGADO, 2012. p.89)

A crise do modelo neoliberal, no âmbito econômico, levou o Governo a reeditar a estratégia de obtenção de saldos positivos na balança comercial pelas exportações, agora do já estruturado agronegócio. Delgado descreve esse retorno à política de geração de superávits na balança comercial com base nos produtos agrícolas da seguinte forma:

\begin{abstract}
"No segundo mandato de FHC se organiza uma tentativa de reedição do modelo de ajustamento externo pelo setor primário, cujas características somente ficarão visíveis no final deste governo e no inicio do seguinte. E neste contexto relança-se a estratégia externa do agronegócio, reeditando em parte a política externa do período 1983/93, mas em novo contexto da economia mundial." (DELGADO, 2012. p.89)
\end{abstract}

Assim, retoma-se o papel fundamental da agricultura na gestão da crise de dependência externa e, de certa forma, finaliza o período de transição da hegemonia do Capital Industrial e seu modelo da modernização conservadora para a organização da produção agrícola e apropriação dos territórios e passa à hegemonia do Capital Financeiro e o agronegócio como seu modelo de exploração para o campo.

Em todo o processo de desenvolvimento do capitalismo no campo brasileiro, muitas foram as alterações, porém algumas características não se alteraram, e são os elementos fundamentais para a análise aqui proposta.

A dependência externa e o papel desempenhado pelo Brasil no mercado mundial, desde a subordinação à Metrópole Colonial na expansão do Capital Mercantil até a consolidação do agronegócio sob hegemonia do Capital Industrial, mantêm-se no decorrer da história. Além disso, mantém-se o papel subimperialista na expansão do modelo da modernização conservadora sob hegemonia do Capital Industrial e, no atual processo de expansão do modelo do agronegócio na nova fase de hegemonia do Capital Financeiro, para além das fronteira nacionais, notadamente, e tratado nesse estudo, para o Paraguai. Esse segundo elemento, que contrasta por um lado a dependência e por outro o subimperialismo brasileiro será tratado nos capítulos seguintes.

A apropriação da terra pelas elites e a característica concentrada das propriedades rurais também manteve-se de forma inalterada, ou, concentrou-se ainda mais no ultimo período, conforme dados dos Censos Agropecuários do IBGE e da FAO. O Brasil é o segundo no ranking dos países com maior concentração fundiária do mundo. Perde apenas, e de fundamental importância para esse estudo, para o Paraguai, que segundo dados do Censo Agropecuário Nacional realizado em 2008 citados pela Cientista Social paraguaia Cecília Vuyk, "por lo menos 4.792 .529 has, equivalentes al $11,78 \%$ del território nacional, se encuentran bajo control de propietarios brasileros. 
(VUYK, 2013, p. 9) Em livre tradução, cerca de $12 \%$ das melhores terras paraguaias estão sob o domínio direto de brasileiros, sendo o desenvolvimento do capitalismo brasileiro e a função que desempenha no mercado mundial fundamental para a determinação das relações no campo paraguaio e a apropriação de seu território.

Trataremos no próximo capítulo da forma de inserção do Brasil no Mercado Mundial a partir da análise teórica do desenvolvimento do Capitalismo dependente brasileiro, para posteriormente retornarmos ao Capital Financeiro na Agricultura e a determinação deste na apropriação dos territórios no Brasil e no Paraguai. 


\section{A INSERÇÃo dOS PAÍSES PERIFÉRICOS E A BUSCA PELA APROPRIAÇÃO DA RIQUEZA}

\subsection{O Subdesenvolvimento e a Dependência - Da Cepal à Teoria Marxista da Dependência}

No capitulo anterior já observamos o elemento da determinação externa na organização da produção agrícola e sua decorrência na apropriação da terra no Brasil. Nesse, buscar-se-á identificar elementos empíricos do desenvolvimento desse processo e elementos teóricos para a compreensão dele.

Dois debates centrais para compreendermos em que incorre a determinação externa estão relacionados ao subdesenvolvimento e a dependência dos países da América Latina. A discussão em torno desses temas, na América Latina em geral e no Brasil em específico foi um elemento de grande dedicação de economistas, sociólogos e historiadores, tendo grande destaque no período de descolonização e independência de antigas colônias no continente africano pós Segunda Guerra Mundial.

A discussão dividiu os teóricos reunidos nas teses Cepalinas ${ }^{9}$ que nortearam os programas desenvolvimentistas e, os intelectuais que questionaram, além dos programas a teoria que os fundamentaram, realizando uma profunda crítica e apontando os limites da linha desenvolvimentista. Dentre os teóricos que desenvolveram as linhas críticas, aqueles que avançaram em uma teoria mais profunda a partir das contradições da América Latina e sua inserção no Mercado Mundial foram os teóricos da Teoria Marxista da Dependência. O economista e professor associado do Instituto de Economia da Universidade Federal de Uberlândia Niemeyer Almeida Filho afirma que o tema da dependência coloca-se na atualidade como um importante elemento na discussão do desenvolvimento, devido principalmente ao processo próprio de desenvolvimento do capitalismo com a sua característica de desenvolver a "alternância entre períodos de expansão e crise" que "reproduzem estruturalmente contradições internas que reproduzem as tensões sociais”. (ALMEIDA FILHO, 2013. p. 11)

Esse autor, coadunando com a afirmação acima justifica a importância da Teoria Marxista da Dependência na seguinte passagem:

\footnotetext{
${ }^{9}$ Comissão Econômica para a América Latina, organismo criado pela Organização das Nações Unidas. Os maiores expoentes do pensamento Cepalino, ou desenvolvimentista, foram Raúl Prebish, Celso Furtado, Ignácio Rangel, Anibal Pinto e Arguiri Emmanuel.
} 
"Esta natureza do capitalismo não é apreendida por concepções metodológicas não holísticas, como o são as concepções keynesiana e neoclássica. Sendo assim, em situação de transição ou crises a perspectiva marxista prevalece e ressurge com vigor. E, em se tratando de América Latina, uma de suas linhas interpretativas mais influentes é a da teoria marxista da dependência." (ALMEIDA FILHO, 2013. p. 11)

Os estudos sobre o desenvolvimento que resultaram na compreensão do processo de subdesenvolvimento tomaram um forte impulso com o processo de descolonização que se segue logo após o final da II Guerra Mundial. O grande intelectual latino-americano Ruy Mauro Marini afirma que o tensionamento derivado das disparidades entre os países é o elemento central desse processo. $\mathrm{O}$ autor afirma que nesse período:

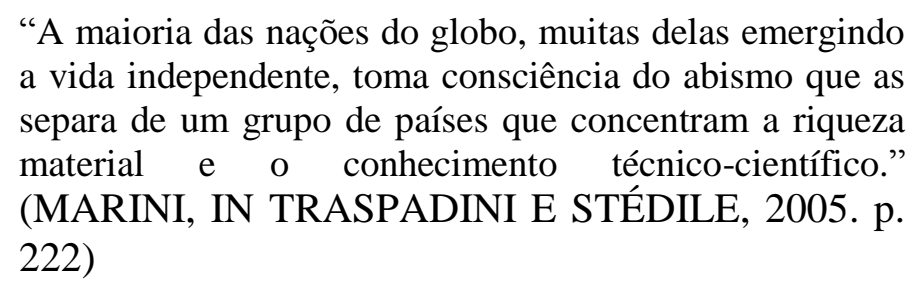

$\mathrm{O}$ autor prossegue afirmando que para resolver as tensões que essas enormes diferenças provocam nas relações internacionais “a Organização das Nações Unidas encorajou a elaboração e teorias destinadas a explicar e justificar essas disparidades." (MARINI, IN TRASPADINI E STÉDILE, 2005. p. 222) É nesse contexto que são criadas as Comissões Econômicas Regionais notadamente nas regiões periféricas e recentemente descolonizadas, assim para a América Latina cria-se a CEPAL.

O incentivo por parte da ONU com a organização da CEPAL promoveu inúmeras discussões em torno o desenvolvimento da América Latina. O esquema explicativo desenvolvido para a compreensão do subdesenvolvimento da região, segundo Marini, "fiel ao padrão proporcionado pela ONU, o considerava como uma etapa prévia ao desenvolvimento econômico". (MARINI, IN TRASPADINI E STÉDILE, 2005. p. 222). Porém a teoria desenvolvida pela CEPAL foi além do que pretendia a ONU e apontou que o subdesenvolvimento é "um resultado das transferências de valor realizadas no plano das relações econômicas internacionais". (MARINI, IN TRASPADINI E STÉDILE, 2005. p. 222) 
Essa afirmação teórica desenvolvida pelos intelectuais vinculados a CEPAL baseava-se na explicação de que essa transferência de valores se daria devido à troca de bens primários com baixo valor agregado por bens industrializados de alto valor agregado. Nesse sentido, essa troca desigual promovia um processo que "descapitalizava a região e deprimia as condições de vida de suas populações" (MARINI, IN TRASPADINI E STÉDILE, 2005. p. 222).

A economista e professora da Universidade da Integração Latino Americana Roberta Traspadini sintetiza o diagnóstico feito pela CEPAL em três elementos: O primeiro é "uma tendência histórica ao desenvolvimento econômico desigual entre centro e periferia" (TRASPADINI, IN. TRASPADINI E STÉDILE, 2005. p. 25), onde o subdesenvolvimento derivaria da relação comercial desigual já afirmada acima com base em Marini.

O segundo elemento é a manutenção da concentração dos benefícios dos avanços tecnológicos no centro do sistema e a periferia, ao invés de se beneficiar desses avanços, financia-o, e, como resultado, produz pobreza e desigualdades sociais, "dada a transferência de valor ocorrida na realização de trocas efetivas nas relações internacionais” (TRASPADINI, IN. TRASPADINI E STÉDILE, 2005. p. 25).

O terceiro elemento é a critica a Teoria Econômica Clássica, principalmente a “Teoria das Vantagens Comparativas" desenvolvida pelo economista clássico David Ricardo. Traspadini, citando Ricardo, explica de forma simples essa teoria que, "quanto mais especializados fossem os países, tanto mais ganhariam nas relações internacionais devido a importante divisão internacional do trabalho." (TRASPADINI, IN. TRASPADINI E STÉDILE, 2005. p. 25) Os cepalinos, conforme já afirmado acima discordaram de tal teoria e afirmaram que os preços dos produtos primários estariam sempre com preços deteriorados diante dos produtos industrializados, assim, para a periferia a especialização na produção de produtos primários ou pouco processados não se configura como um vantagem, ao contrário, promove a transferência de valor para o centro e o empobrecimento crescente na periferia.

A resposta dada pela CEPAL decorreu dessa formulação teórica. Para superar as condições do subdesenvolvimento os intelectuais desenvolvimentistas apontaram como saída a equalização dos termos de troca nas relações comerciais. Assim, nos afirma 
Marini, "a Cepal preconizava uma política de industrialização, assegurada por um marcado protecionismo estatal”. (MARINI, IN TRASPADINI E STÉDILE, 2005. p. 222).

O programa oferecido pela CEPAL para a superação do subdesenvolvimento através da equalização das relações de troca e do melhor posicionamento das economias periféricas no mercado mundial passou por quatro elementos norteadores.

O primeiro elemento era a industrialização dos países combinada com a ampliação do mercado interno. Esse processo inicia-se, segundo Traspadini, com o: "Modelo de industrialização substitutiva de importações para a implementação da indústria de base nos países do continente." (TRASPADINI, IN. TRASPADINI E STÉDILE, 2005. p. 25)

O segundo elemento apresentado pela autora que compõe o projeto político cepalino é o papel desempenhado pelo Estado. Para solucionar, por um lado o subdesenvolvimento e por outro a desigualdade social o Estado deveria assumir o papel de "promotor do desenvolvimento a partir de políticas públicas de industrialização e distribuição de renda, que gerassem mercado interno para a indústria nacional $e$ representassem diminuição da desigualdade." (TRASPADINI, IN. TRASPADINI E STÉDILE, 2005. p. 25)

O terceiro elemento do programa baseava-se na incorporação do progresso tecnológico de maneira mais rápida quanto possível, dando maior destaque aos setores prioritários da economia. A incorporação de novas bases técnicas de produção, vinculadas à interiorização da indústria e a integração agricultura-indústria, já descrita no capitulo anterior, também apresentavam-se como elementos centrais do processo de desenvolvimento proposto.

O quarto elemento consistiria na alteração da pauta de exportação, baseando-se na crítica à teoria clássica das vantagens comparativas, a produção nacional deveria ampliar a agregação de valor nos produtos nacionais e participar do mercado mundial concorrendo com os setores com mais tecnologia incorporada, evitando a especialização em produtos primários.

Almeida Filho afirma que as décadas de 1950 e 1960, marcadamente, foi o período onde as ideias cepalinas foram o "modelo hegemônico de interpretação e de 
proposições de políticas de desenvolvimento" (ALMEIDA FILHO, 2013. p. 11). Traspadini afirma que, esse modelo, além de dominar a discussão intelectual, "serviu de base para as propostas concretas de governo em vários países do continente, especialmente México, Argentina e Brasil” (TRASPADINI, IN. TRASPADINI E STÉDILE, 2005. p. 26).

No primeiro capitulo, ao discutirmos o desenvolvimento da questão agrária brasileira, apresentamos vários elementos que permeiam as teses desenvolvimentistas, principalmente no período de transição da hegemonia do Capital Mercantil para a hegemonia do Capital Industrial. Esse período, caracterizado fundamentalmente pelo desenvolvimento da indústria e a integração e subordinação da agricultura, poderia ser explicado como de implementação das teses cepalinas, porém apenas em partes.

É notável a forte influência e os traços das propostas cepalinas no desenvolvimento da questão agrária brasileira, mas a correlação de forças internas e a determinação externa pelo centro imperialista limitaram seu grau de influência e lhe ceifaram as propostas mais importantes.

A influência desenvolvida no Brasil teve seu auge no período anterior ao Golpe de 1964 e foi permeada em algumas ações nacionalistas desenvolvidas durante os governos militares, porém sempre lhe retirando pontos vitais. Traspadini afirma que:

"No Brasil, essas ideias tiveram enorme influencia
política, devido ao grau de inserção desses intelectuais
cepalinos no governo Goulart, sobretudo pelo papel que
Celso Furtado exerceu nessa gestão de governo como
ministro do Planejamento." (TRASPADINI, IN. TRASPADINI E STÉDILE, 2005. p. 26)

A autora ainda afirma que, na prática, nunca foi possível verificar a aplicação da totalidade do projeto político cepalino. O governo de Goulart foi interrompido pelo Golpe Militar de 1964 e nos governos militares que se seguiram as propostas mais progressistas vinculadas ao programa cepalino foram ceifadas. Discorrendo sobre a superação histórica do programa cepalino, Traspadini afirma que as ideias e propostas desenvolvimentistas somente foram "utilizadas de forma reduzida e manipulada pelos interesses 'nacionalistas' dos militares em exercício no poder". (TRASPADINI, IN. TRASPADINI E STÉDILE, 2005. p. 27) 
Assim, embora pode-se observar vários elementos importantes das teses cepalinas, principalmente o da industrialização e da integração agricultura-indústria, no desenvolvimento da questão agrária brasileira, um dos elementos centrais foi lhe retirado. $\mathrm{Na}$ proposta cepalina de desenvolvimento da indústria nacional, um dos elementos determinantes era o fortalecimento do mercado interno, que passava necessariamente por políticas de distribuição de renda, já apresentado anteriormente, e, que nas quais estavam presentes a interiorização da indústria e a Reforma Agrária.

Dessa forma, a correlação de forças presente no final da década de 1950 e inicio da década de 1960 que possibilitou a incorporação das teses cepalinas nos programas de governo foi alterada profundamente com o Golpe de 1964, seja por elementos internos ou externos. Dentre os elementos internos destaca-se o enorme poder político das oligarquias rurais contrárias a Reforma Agrária e o receio dos setores industriais no avanço de ideias socialistas e comunistas o que, para eles, estavam presentes nas Reformas de Base propostas pelo governo Goulart. Externamente, no campo da geopolítica, há uma mudança na estratégia de dominação imperialista na região, adotando o modelo das ditaduras militares e com essas, a diminuição das condições para as lutas por direitos dos setores empobrecidos e, a necessidade de fazer concessões pelos setores vinculados ao imperialismo. Traspadini afirma que "a mudança de estratégia do imperialismo no continente, com a implantação das ditaduras militares, também foi um limitador na concretização das ideias cepalinas." (TRASPADINI, IN. TRASPADINI E STÉDILE, 2005. p. 27)

Assim, essa autora contrapõe a teoria e a prática para expor o limitado alcance e o alterado objetivo das propostas cepalinas afirmando que:

\footnotetext{
"Se, por um lado, foram implementadas políticas de cunho nacionalista nos países economicamente mais desenvolvidos da América Latina, por outro lado, no interior de cada um desses países, não funcionou a implementação de um Estado do bem-estar social que conjugasse as reformas estruturais com as políticas econômicas essenciais." (TRASPADINI, IN. TRASPADINI E STÉDILE, 2005. p. 26)
}

O modelo de substituição de importações, uma proposta com a tintura cepalina, foi implementado durante a ditadura, e promoveu uma mudança da pauta de exportações brasileiras, mas, segundo Traspadini, “as custas de uma maior 
concentração de riqueza e renda e, consequentemente, da ampliação das distâncias entre ricos e pobres" (TRASPADINI, IN. TRASPADINI E STÉDILE, 2005. p. 27). Outro elemento contrastante é de que a mudança na pauta de exportações não repercutiu na redução dos valores transferidos pela periferia na sua relação comercial com o centro capitalista nem no possível desenvolvimento do mercado consumidor interno de massas. A autora, sobre a limitação nas propostas cepalinas e ainda mais na implantação desvirtuada dessas pelos governos militares, afirma que o modelo aplicado:

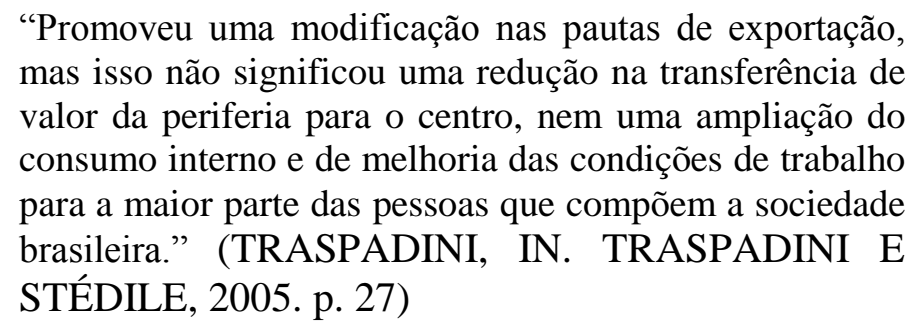

Seja pela sua implementação desvirtuada, seja pelo seu limite prático em resolver o problema da dependência o arcabouço teórico e o receituário cepalino já na década de 1960 começou a ser questionado. Marini afirma que:

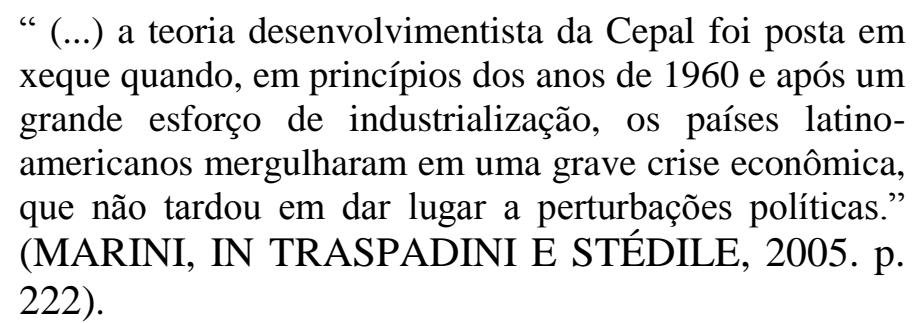

É no contexto da crítica as teses cepalinas que desenvolve-se as teorias da dependência. Almeida Filho afirma que:
“ (...) os primeiros resultados são do final dos anos de 1960 e início dos 1970, com a publicação dos trabalhos seminais de Fernando Henrique Cardozo, Enzo Falleto, Theotonio dos Santos, Vânia Bambirra e Ruy Mauro Marini." (ALMEIDA FILHO, 2013. p. 11).

O próprio Ruy Mauro Marini, em artigo publicado em 1992, afirma que debruçando-se sobre os problemas concretos que se apresentaram no período de crise pós-industrialização nas economias latino-americanas é que se desenvolve a teoria da dependência. $\mathrm{O}$ autor nos contextualiza que "insistindo sobretudo nos problemas financeiros e tecnológicos criados pela desnacionalização de nossas economias, se constitui a teoria da dependência" (MARINI, IN TRASPADINI E STÉDILE, 2005. p. 222). 
Utiliza-se aqui uma pluralidade quando falamos em teoria da dependência pois no decorrer das críticas, logo construiu-se uma diferenciação teórica que configurou em duas teorias. Almeida Filho, citando a historiadora Diana Hunt, refere-se aos aportes da dependência "denotando acordo apenas parcial dos estudiosos do tema em relação ao objeto de estudo, porém significativas diferenças metodológicas” (ALMEIDA FILHO, 2013. p. 11).

Desenvolveram-se a partir das críticas iniciais duas concepções distintas, uma de clara orientação marxista representada por Marini, Bambirra e Dos Santos, a qual ressalta-se sua maior importância neste trabalho para a compreensão dos processos econômicos-sociais decorrentes da apropriação do território e organização da produção agrícola no Brasil e sua decorrente expansão subimperialista para o Paraguai, que será tratado mais a frente. A outra concepção foi a vertente weberiana representada por Cardoso, Falleto e por José Serra.

A principal diferença que resultou a conformação de duas teorias da dependência distintas deu-se em torno o próprio conceito de dependência. Para os weberianos, representados principalmente por Cardoso, a dependência se constituía numa situação, assim não existia "a dependência dos países periféricos" e sim "situações de dependência de países periféricos". Para os marxistas a dependência constitui-se numa categoria essencial para a compreensão da inserção das economias periféricas no sistema capitalista global.

Cardoso afirma que:

"Assim, a ideia de dependência, na medida em que se define no universo de discurso teórico a que estou aludindo, nem é uma categoria geral que dissolve as diferenças entre as várias partes que compõem uma situação de dependência, nem é apenas o resultado da reprodução no pensamento de uma ou de cada uma das relações entre classes, estados e economias." (CARDOSO, IN SERRA, 1979. p. 373)

A passagem acima deixa claro a concepção de Cardoso sobre o status da dependência como uma situação determinada por "uma estrutura dada de dominação e quais os limites possiveis de seu funcionamento" (CARDOSO, IN SERRA, 1979. p. 373), ou seja, seu alcance está limitado a situações concretas e conjunturais nas quais as economias 
periféricas se encontram. Assim, não apreendendo um elemento de realidade inerente às economias periféricas, não poderia constituir-se numa categoria de análise.

A formulação teórica marxista partia de uma análise com dois pressupostos fundamentais, o primeiro é que ela "apreendia o desenvolvimento capitalista latino-americano com especificidades relevantes o suficiente para exigir interpretação própria”, o segundo é que "partia da concepção do capitalismo como um sistema global, no qual as inserções históricas das sociedades e economias nacionais cumpriam funções específicas e tendencialmente estáveis" (ALMEIDA FILHO, 2013. p. 11). Dessa forma a dependência não se configura como uma situação historicamente específica e temporalmente dada e sim em uma categoria de análise.

Ruy Mauro Marini, em sua obra "Dialética da Dependência" fornece o fundamento dos pressupostos colocados acima. $\mathrm{O}$ autor afirma que na América Latina "o que se tem é um capitalismo sui generis, que só adquire sentido se o contemplamos na perspectiva do sistema em seu conjunto, tanto em nível nacional, quanto, $e$ principalmente, em nível internacional”. (MARINI, IN TRASPADINI E STÉDILE, 2005. p. 138). 


\subsection{A Interpretação Marxista - Teoria Marxista da Dependência}

Para a compreensão da forma de apropriação da terra e de organização da produção agrícola no Brasil e sua influência determinante no Paraguai faz-se necessário iluminar o processo de inserção no Mercado Mundial e elucidar o papel da burguesia brasileira, em especial da burguesia agrária.

Já foi observado no primeiro capitulo a inserção subordinada do território latino americano ao desenvolvimento do capitalismo mundial. Desde o processo de colonização, relacionado ao Capital Mercantil até os dias atuais sob hegemonia do Capital Financeiro. Marini apresenta o processo de integração da América Latina na seguinte passagem: "Forjada no calor da expansão comercial promovida no século 16 pelo capitalismo nascente, a América Latina se desenvolve em estreita consonância com a dinâmica do capitalismo internacional". (MARINI, IN TRASPADINI E STÉDILE, 2005. p. 140). Assim, nos é importante, determinar quais as funções são assumidas pelos países dependentes nessa dinâmica, como elas determinam o subdesenvolvimento e a dependência e quais mecanismos são fundamentais para a burguesia interna. Tais mecanismos, especialmente a superexploração da força de trabalho e o subimperialismo são os elementos fundamentais para a análise da apropriação do território brasileiro, da organização da produção agrícola e da influência direta nesses aspectos no território paraguaio.

Já havia sido identificado pelos intelectuais cepalinos que o subdesenvolvimento derivava de uma relação no comercio internacional onde os termos de troca estavam depreciados em desfavor às economias periféricas. Porém coloca-se necessário estabelecer a partir de uma compreensão mais profunda sobre qual função é estabelecida pela América Latina no desenvolvimento do Capitalismo Mundial, como se depreciam essas relações de comércio exterior e como se comportam as classes dominantes internamente nos países periféricos.

Já se afirmou anteriormente ao tratarmos da Questão Agrária no Brasil a função desempenhada pelo país no desenvolvimento do capitalismo mundial, cabe aqui apenas reforçarmos os elementos teóricos de compreensão desse fenômeno.

Embora a América Latina, após a colonização sempre esteve sobre a determinação do Capital, as funções desempenhadas no período colonial são distintas 
das funções desempenhadas posteriormente, Marini sobre a América latina afirma que "somente no curso do século 19, e especificamente depois de 1840, sua articulação com essa economia mundial se realiza plenamente. (MARINI, IN TRASPADINI E STÉDILE, 2005. p. 142)

Esse autor acrescenta que: "Isso se explica se considerarmos que é com o surgimento da grande indústria que se estabelece com bases sólidas a divisão internacional do trabalho” (MARINI, IN TRASPADINI E STÉDILE, 2005. p. 142). Assim, é a divisão internacional do trabalho a condição determinante para a dependência, e, é a grande indústria que consolida o mercado mundial que garante a essa divisão. Mas não poderia a grande indústria desenvolver-se somente nas esferas nacionais, assim a inserção da América Latina desempenhou dois papéis importantes para o desenvolvimento do capitalismo nos países centrais antes mesmo do desenvolvimento da dependência.

O primeiro elemento é o papel central na Acumulação Primitiva de capital que possibilitou o desenvolvimento do capitalismo industrial e de seu elemento central a grande indústria. Dentre os elementos descritos por Marx no capitulo XXIV de sua obra “O Capital”, no qual desvela o processo de acumulação originário ou primitivo por parte do capital, encontra-se o papel fundamental que cumpriu o saque realizado aos recursos naturais e aos povos nos territórios colonizados, conforme já citado anteriormente.

O grande escritor uruguaio Eduardo Galeano em seu clássico "Veias Abertas da América Latina” citando cálculos de Earl Hamilton afirma que: “Entre 1503 e 1660, desembarcaram no porto de Sevilha 185 mil quilos de ouro e 16 milhões de quilos de prata." (GALEANO, 2011. p. 44) O autor com esse exemplo deixa claro o saque e a pilhagem que representou o período colonial e, o papel fundamental disso no desenvolvimento do capitalismo nos países centrais. O próprio Galeano afirma: " $O s$ metais arrebatados aos novos domínios coloniais estimularam o desenvolvimento europeu e até se pode dizer que o tonaram possível." (GALEANO, 2011. p. 44)

Marini, reforça os elementos descritos por Marx e Galeano afirmando que:

“(...) a América Latina contribuiu em um primeiro momento com o aumento do fluxo de mercadorias e a expansão dos meios de pagamento, que, ao mesmo tempo em que permitiam o desenvolvimento do capital comercial e bancário na Europa, sustentaram o sistema 
manufatureiro europeu e propiciaram o caminho para a criação da grande indústria." (MARINI, IN TRASPADINI E STÉDILE, 2005. p. 140)

Assim, com base nesses três autores, tendo em Marini sua síntese afirma-se com clareza a primeira função que a América Latina cumpre no desenvolvimento no capitalismo mundial.

O segundo elemento decorre do próprio fato de sua inserção no comércio internacional, é a invasão e colonização dos territórios latino-americanos, asiáticos e africanos que gerará como resultado a própria criação de um mercado mundial desenvolvido. Marx, descrevendo a gênese do capitalista industrial, afirma que: "As colônias asseguravam mercados à manufaturas em expansão e, graças ao monopólio, uma acumulação acelerada” (MARX, 2013. p. 875). Assim o capitalismo industrial teve as condições para seu rápido desenvolvimento atendendo "as necessidades do novo mercado mundial criado pelas grandes descobertas dos fins do século XV' (MARX, 2013. p. 871).

Assim, após o cumprimento dessas funções iniciais, com a divisão internacional do trabalho definida é que se desenvolve e estrutura econômica e de relações entre o centro e a periferia do sistema capitalista e se conforma a dependência. Marini, nesse sentido, afirma que:

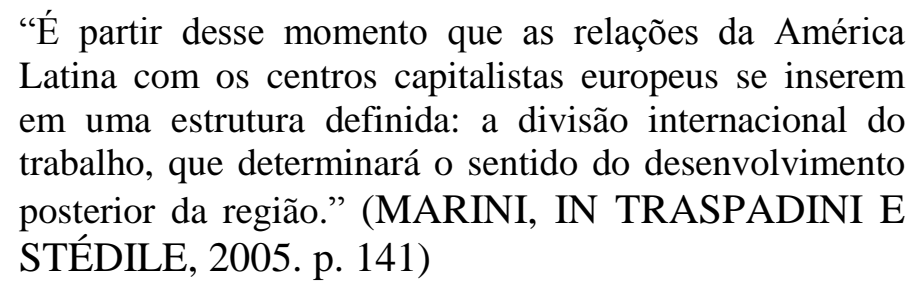

O autor conceitua dessa forma o que é a dependência, avançando e diferenciando das afirmações de Gunder Frank, outro importante intelectual que desenvolveu esse conceito. Marini afirma que "a situação colonial não é o mesmo que a situação de dependência” (MARINI, IN TRASPADINI E STÉDILE, 2005. p. 141) e, embora o processo de subordinação dos países periféricos, de exploração e saque de suas riquezas tenham continuidade histórica há diferenças qualitativas na forma dessa exploração, não sendo uma continuidade homogênea. Marini conceitua a dependência como:

“(...) entendida como uma relação de subordinação entre nações formalmente independentes, em cujo marco as relações de produção das nações subordinadas são 
modificadas ou recriadas para assegurar a reprodução

ampliada da dependência." (MARINI, IN

TRASPADINI E STÉDILE, 2005. p. 141)

Para realizarmos a análise da apropriação do território no Brasil e sua influência predominante na apropriação do território no Paraguai coloca-se necessário compreendermos como configura-se a dependência nas relações econômicas.

Partindo da constatação e afirmação dos intelectuais cepalinos sobre o subdesenvolvimento, que este deriva de uma dada relação comercial em que o preço dos produtos oriundos dos países periféricos apresenta-se depreciado em relação aos preços dos produtos oriundos dos países centrais, a teoria marxista da dependência, e Ruy Mauro Marini como o principal formulador, foi quem desvelou esse fenômeno, partindo da mera aparência a que representam os preços e compreendendo a transferência de valores entre os países.

Marini ao expor o segredo da troca desigual apresenta dois elementos que compões esse processo, o primeiro refere-se às diferentes produtividades e composições orgânicas dos capitais presentes em cada país e, a segunda refere-se ao monopólio da produção de certas classes de mercadorias por parte dos países centrais.

O primeiro elemento não poderia ser explicado sem um aprofundamento teórico marxista e um elementar rigor metodológico desenvolvido por Marini. O autor expressa que para a compreensão do fenômeno de transferência de valores entre as nações é necessário "deixar de lado a explicação simplista que não quer ver ali nada mais do que o resultado da lei de oferta e procura" (MARINI, IN TRASPADINI E STÉDILE, 2005. p. 149) e, não se limitar a "constatar empiricamente que as leis mercantis tem sido falseadas no plano internacional, graças a pressão diplomática e militar por parte das nações industriais”. (MARINI, IN TRASPADINI E STÉDILE, 2005. p. 149)

Para compreender a forma de explicação de Marini é importante retomar-se alguns elementos básicos da teoria marxista. Partindo-se a análise de que as mercadorias são trocadas por seus valores, que se expressam no mercado na forma aparente de preço. O Valor, em Marx, é dado pela quantidade de trabalho novo incorporado em uma mercadoria. Marini afirma que "o intercâmbio de mercadorias expressa a troca de equivalentes, cujo valor se determina pela quantidade de trabalho socialmente necessário que as mercadorias incorporam". (MARINI, IN TRASPADINI E 
STÉDILE, 2005. p. 151) Assim, para solucionar a questão de como ocorre uma transferência sistemática de valores dos países periféricos para os países centrais deve vir daí a explicação mais coerente.

Marini, desvenda a dependência retomando o conceito de Composição Orgânica de Capital como ponto de partida teórico, trilha o caminho das tendências da concorrência intercapitalista e, a partir de uma reflexão baseada na realidade empiricamente apreendida, aplica essa reflexão nas relações entre os países. A conclusão à que chega Marini é que a transferência de valores entre os países se dá de maneira constante dos países com menor composição orgânica do capital para os países com maior composição orgânica do capital e esse processo rege-se pelas leis capitalistas de desenvolvimento. Assim a dependência não pode ser superada senão pela superação das relações capitalistas de produção, nas palavras do autor:

"A consequência da dependência não pode ser, portanto, nada mais do que maior dependência, e sua superação supõe necessariamente a supressão das relações de produção nela envolvida" (MARINI, IN TRASPADINI E STÉDILE, 2005. p. 141)

A Composição Orgânica do Capital, decorre do nível de desenvolvimento tecnológico utilizado na produção e é dada pela razão do Capital Constante e o Capital Total de uma dada produção, ou seja, o total despendido com máquinas, equipamentos, matérias-primas e, a soma deste com o que despende-se no pagamento da força de trabalho. Zavaski, descreve a composição orgânica do capital como sendo:

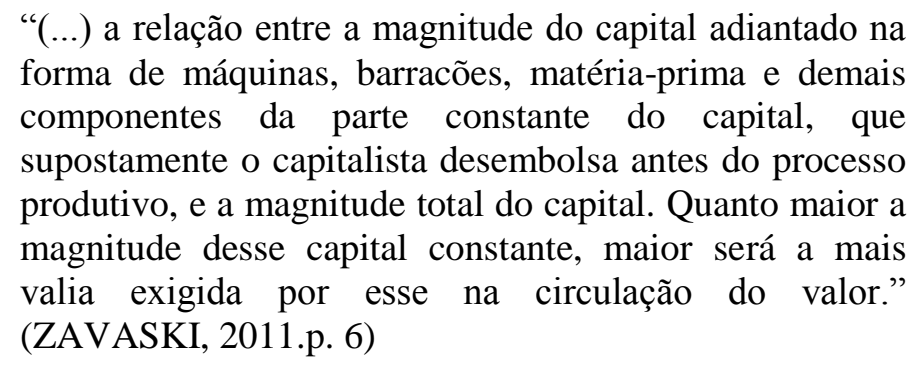

A afirmação que finaliza a passagem acima é o elemento que Marini busca para compreender a transferência de valor entre países tecnologicamente menos avançados para os países centrais. Zavaski, com base em Marini e na teoria marxista, prossegue afirmando que:

"Quanto maior a composição, mais desenvolvida
tecnologicamente será a fábrica, o ramo de produção ou o 
país. A maior composição orgânica de um capital em relação a outro, no mesmo ramo da produção ou em ramos diferentes, ou mesmo entre países diferentes, sempre determinará uma transferência de valor do ramo com menor composição orgânica para o ramo com maior composição." (ZAVASKI, 2011.p. 6)

Adotando-se um exemplo prático supondo-se que três empresas em concorrência possuem a mesma quantidade de capital. Ao investirem no mesmo ramo de produção, apresentam uma composição orgânica do capital diferenciada, a primeira empresa apresenta uma composição orgânica de 0,7 , ou seja, $70 \%$ do seu capital investido em capital constante e 30\% em capital variável. Seguindo o exemplo hipoteticamente a segunda empresa apresenta uma composição orgânica de 0,8 , ou seja, $80 \%$ investido em capital constante e $20 \%$ em capital variável e, a terceira empresa apresenta a composição orgânica de 0,9 , tendo $90 \%$ do seu capital constante e apenas $10 \%$ variável. Zavaski, discorrendo sobre a formação do lucro médio e a concorrência intercapitalista desenvolveu, com base em Netto \& Braz (NETO \& BRAZ, 2002. p. 145), um exemplo com um capital hipotético de 10000 e uma taxa de mais valia de $100 \%$, obtendo a seguinte tabela:

Tabela 1: formação do lucro médio e transferência de valor

\begin{tabular}{|c|c|c|c|c|c|c|}
\hline & $\mathrm{c}+\mathrm{v}$ & $\mathrm{c}$ & $\mathrm{V}$ & $\mathrm{m}$ & $\mathrm{lm}$ & \\
\hline Empresa A & 10000 & 7000 & 3000 & 3000 & 2000 & perde 1000 \\
\hline Empresa B & 10000 & 8000 & 2000 & 2000 & 2000 & \\
\hline Empresa C & 10000 & 9000 & 1000 & 1000 & 2000 & ganha 1000 \\
\hline Total & 30000 & 24000 & 6000 & 6000 & 6000 & \\
\hline
\end{tabular}

Fonte: ZAVASKI (2011)

Na tabela acima, 'c' é o capital constante, 'v' é o capital variável, 'm' é a maisvalia produzida e, ' $1 \mathrm{~m}$ ' o lucro médio apropriado por cada empresa de forma individual. Se observarmos, nesse exemplo, que apenas pelo fato de ter uma maior composição orgânica do capital a terceira empresa, que para Marini pode ser um país específico, se apropria não dos 1000 gerado no seu processo produtivo, mais sim de 2000, já começase a compreender os segredos da dependência.

Se as relações internacionais confrontam no mercado mundial nações com maior composição orgânica do capital, com nações de menor composição orgânica do capital, numa situação de concorrência perfeita, que obviamente não corresponde à realidade, já 
ocorreriam grandes transferências de valor sem nenhuma necessidade coercitiva, nem de adoção de preços acima do valor real das mercadorias.

Além do processo descrito anteriormente, em que adotamos o preço de venda com a mesma magnitude do valor, pode-se observar outro processo relacionado ao progresso tecnológico. Marini afirma que:

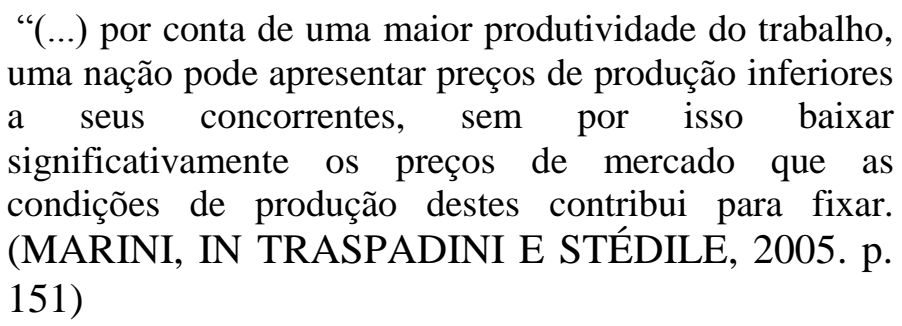

$\mathrm{O}$ autor está nos afirmando nessa passagem, que num determinado período em que um país eleva sua produtividade, mas mantém os mesmos preços de mercado, configura-se numa transferência de valor ainda maior do que aquela dada pelo lucro médio, assim, "isso se expressa, para a nação favorecida, em um lucro extraordinário" (MARINI, IN TRASPADINI E STÉDILE, 2005. p. 151).

Adotamos aqui a concepção marxista de valor, ou seja, o valor é dado pela quantidade de trabalho socialmente necessário para a produção de determinada mercadoria, assim, no mercado, são confrontados e trocados valores, não havendo nenhum valor novo criado no processo de compra e venda. Partindo dessa afirmação no mercado se alguém ganha, alguém perde valor, neste trabalho, se um país se apropria de um valor a mais, algum país está perdendo esse valor.

A obtenção de lucro extraordinário por uma nação ou por um capitalista individual, em uma fase de capitalismo concorrencial, só pode ser realizada de forma esporádica, pois tendencialmente a tecnologia que propiciou a maior produtividade será adotada pelos demais países. Entra em cena a função do monopólio, elemento esse que propicia a perenização do lucro extraordinário, recebendo no marxismo, a denominação de lucro de monopólio. Sobre esse aspecto Marini afirma que:

“(...) o mero fato de que umas (nações) produzam bens que as outras não produzem, ou não o fazem com a mesma facilidade, permite que as primeiras iludam a lei do valor, isto é, vendam os seus produtos a preços superiores a seu valor, configurando assim uma troca desigual." (MARINI, IN TRASPADINI E STÉDILE, 2005. p. 152) 
Assim, reforça-se três elementos teóricos que para Marini, são o segredo da troca desigual. O primeiro que na formação do lucro médio promove uma transferência de valor dos países com composição orgânica do capital menor para os países com maior composição. O segundo é a obtenção de lucros extraordinários pelas nações que alcançam níveis de produtividade mais altos e não alteram os preços de mercado e; $\mathrm{O}$ terceiro elemento é a obtenção de lucros de monopólio, determinando preços permanentemente acima do valor real das mercadorias. Marini afirma que:

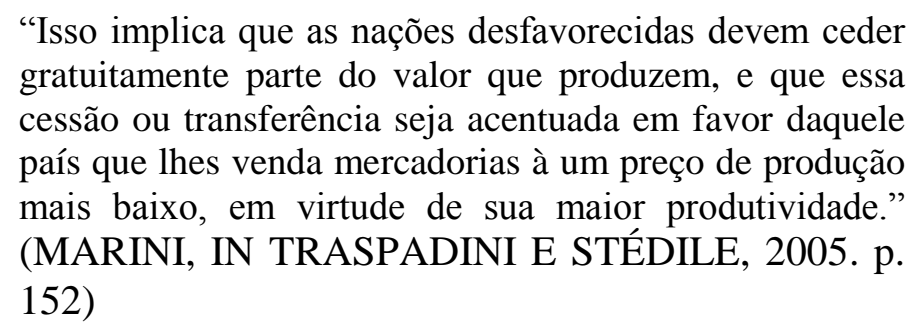

Dessa forma, a colonização e posteriormente a dependência, que já foi apresentado anteriormente como um processo de exploração dos países centrais que se sucedem temporalmente, mas ressalvado que são formas distintas, mantém um fluxo constante de riquezas dos países periféricos para os países centrais. Essa transferência de valor gera, por parte das burguesias internas, mecanismos de compensação de suas perdas na relação comercial. Os dois mecanismos centrais, que nos referiremos a frente são a superexploração e o subimperialismo. Segundo Marini:

"Frente a esses mecanismos de transferência de valor, baseados seja na produtividade, seja no monopólio de produção, podemos identificar - sempre no nível das relações internacionais de mercado - um mecanismo de compensação." (MARINI, IN TRASPADINI E STÉDILE, 2005. p. 152)

$\mathrm{O}$ autor refere-se na passagem acima a superexploração, mas inicia, nesse sentido, afirmando que as nações desfavorecidas buscam incrementar o valor trocado no comércio internacional a fim de equilibrar a diferença transferida. Dois elementos são importantes nesse sentido, em que consiste o valor transferido pelos países periféricos, e, como países periféricos fazem a compensação de suas perdas.

No exemplo que utilizou-se para a explicação da formação de um lucro médio e de transferência de valores entre empresas com composição orgânica do capital diferenciadas já havia ficado claro o elemento da mais-valia. Ou seja, as transferências de valores se dão na esfera dos valores à mais não pagos ao trabalhador e que são 
apropriados pelo capital na forma de mais-valia, assim a transferência de valores são na realidade a transferência de mais-valia produzida em cada país. Marini afirma que:

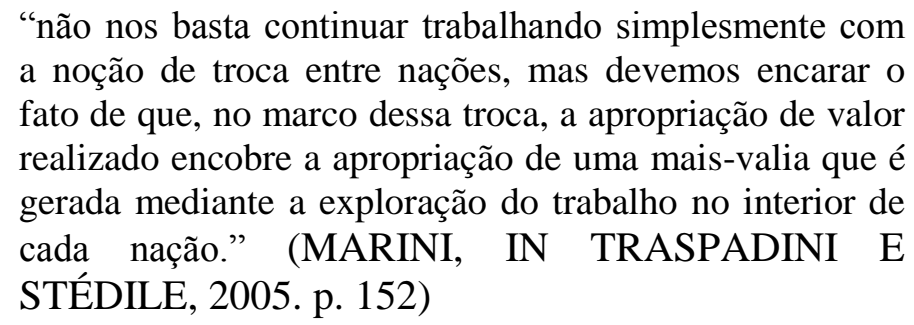

A concorrência intercapitalista determina assim, a quantidade de mais-valia extraída dos processos produtivos que será apropriada por cada capital de forma individual ou, nesse caso, nacional. No caso em estudo, a dependência, verifica-se uma constante transferência de mais-valia dos países periféricos para os países centrais, ou seja, uma parcela importante da mais-valia extraída pelos capitalistas internos das nações periféricas é apropriada pelos capitalistas das nações centrais. O autor em questão é mais incisivo nesse aspecto ao afirmar que:

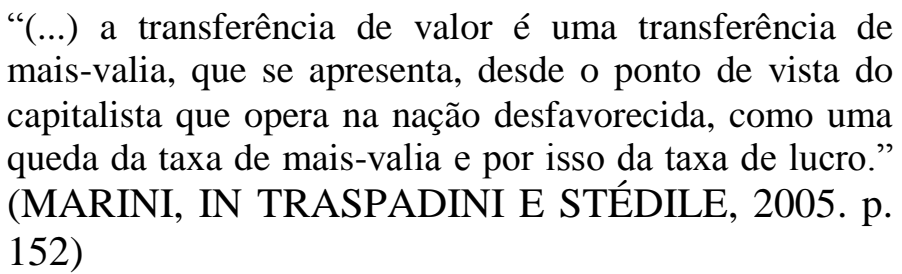

Precisando esse elemento conceitual, de que a substância que compõe os valores transferidos na troca desigual estabelecida no mercado mundial pelos países da América Latina, podemos compreender como pode-se dar e, como a burguesia interna busca realizar a sua compensação. Na formulação de Marini é desvendado tanto as possibilidades de compensação e superação da troca desigual, quanto clareado quais foram as opções da burguesia brasileira e, como essas opções determinaram a apropriação do território paraguaio e a organização de sua produção agrícola.

Desmembrando a afirmação anterior para avançarmos, já se apresentou anteriormente, com base no autor em questão, que a única forma de superação da dependência, alternado assim o processo da troca desigual, é a superação das relações de produção que são a base do sistema, tal seja, as relações de produção capitalistas. Assim Marini afirma que a única forma de superação da dependência é a superação do Capitalismo. Como essa saída decorreria de uma correlação de forças internas nos países dependentes em favor dos trabalhadores, não foi essa a opção das burguesias 
internas. As burguesias internas buscaram saídas de recomporem suas taxas de lucro sem confrontar os países centrais, no plano político inclusive aliando-se ao imperialismo para sufocar o movimento dos trabalhadores dentro de suas fronteiras. Trataremos mais a frente das relações com o imperialismo e do 'mecanismo' subimperialista para se posicionar melhor no campo de apropriação de riqueza do mercado mundial. 


\subsection{Mecanismos de Compensação da Dependência}

\subsubsection{Superexploração da Força de Trabalho}

Dentre as possibilidades de compensação das perdas na relação comercial sem rompimento com a lógica da dependência o primeiro mecanismo explorado pela burguesia interna brasileira foi lançar mão de um processo de aumento da exploração dos trabalhadores, aumentando a massa de mais-valia extraída. Marini afirma que:

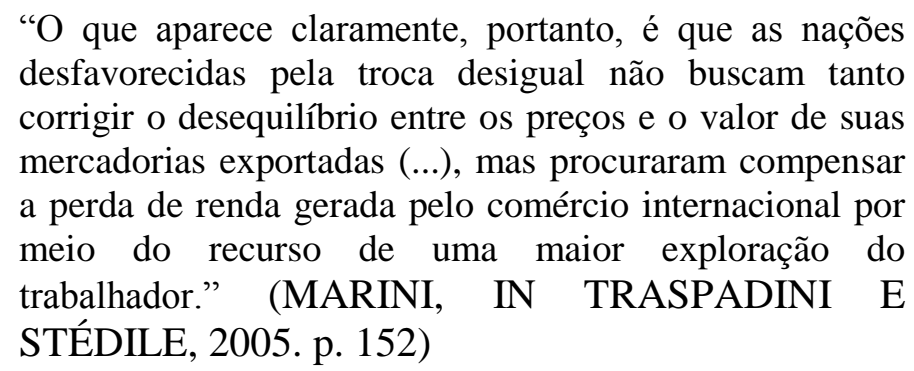

O autor sustenta que a burguesia interna foi incapaz de contrapor a transferência de valor e para recompor sua taxa de lucro lançou mão da superexploração dos trabalhadores nas relações de produção internamente, e, veremos mais a frente, ao mecanismo do subimperialismo nas relações com os países mais periféricos.

A forma de compensação das perdas nas relações comerciais através do aumento da massa de mais-valia extraída dos trabalhadores basicamente dá-se de três formas: o aumento da intensidade do trabalho, o aumento da jornada de trabalho e, a redução do consumo do trabalhador abaixo do mínimo humanamente aceitável.

Marini afirma que: "O aumento da intensidade do trabalho aparece, nessa perspectiva, como um aumento da mais-valia, obtido através de uma maior exploração do trabalhador e não do incremento de sua capacidade produtiva" (MARINI, IN TRASPADINI E STÉDILE, 2005. p. 154). Assim, o processo produtivo é mantido da mesma forma, sem nenhum incremento de tecnologia, apenas, através de mecanismos indutivos tais como o risco do desemprego, o uso da força, o assédio moral e o pagamento por produto, para obter uma produção maior na mesma jornada de trabalho. Isso implica apenas num aumento da produção a custa de um maior desgaste do trabalhador, na atualidade uma observação importante desse processo é a forma de contratação dos trabalhadores empregados nas colheitas de cana-de-açúcar, café e laranjas. 
O aumento da jornada de trabalho é o clássico mecanismo de aumentar a massa de mais-valia através de aumento do tempo de trabalho excedente, para Marini esse é o mecanismo de "aumento da mais-valia absoluta na sua forma clássica" (MARINI, IN TRASPADINI E STÉDILE, 2005. p. 154). Nesse formato de aumento da exploração dos trabalhadores também são várias as formas de sua visualização no concreto, seja na definição de metas de produção, onde o trabalhador fica um tempo além de sua jornada de trabalho 'voluntariamente' porque não cumpriu a sua meta no tempo previsto, nessa forma vemos um mecanismo conjugado com o anterior. Outro mecanismo é o aumento mesmo da extensão da jornada de trabalho, não possível em países com o movimento operário mais pujante e organizado mas, extremamente possível nos países dependentes e, um terceiro mecanismo é a utilização de horas-extras. Assim, nosso autor afirma que "trata-se aqui de aumentar simplesmente o tempo de trabalho excedente, que é aquele que o operário continua produzindo depois de criar um valor equivalente ao dos meios de subsistência para seu próprio consumo." (MARINI, IN TRASPADINI E STÉDILE, 2005. p. 154)

O terceiro mecanismo é o de remunerar o trabalhador abaixo do nível necessário para a produção e reprodução da sua força de trabalho, ou seja, pagar pela força de trabalho um preço abaixo do seu valor real. Nesse sentido, o que é necessário para a garantia da vida do trabalhador torna-se parte do lucro do capitalista, Marini citando Marx afirma que "o fundo necessário de consumo do operário se converte de fato, dentro de certos limites, em um fundo de acumulação do capital” (MARINI, IN TRASPADINI E STÉDILE, 2005. p. 154)

Dois elementos são necessários serem observados, o primeiro é que não é necessário a dependência e a troca desigual para que os mecanismos acima sejam colocados em prática pelos capitalistas, porém, são em economias periféricas que aparecem as condições para a sua generalização. $\mathrm{O}$ aumento do exército industrial de reserva, fruto da exclusão de milhares de camponeses do acesso a terra, como observamos no primeiro capitulo, uma ainda reduzida capacidade produtiva das classes trabalhadoras, uma forte repressão e o uso da força para manter tanto a organização em níveis baixos quanto os próprios salários, dada a generalização das ditaduras militares na América Latina, são características essenciais para tornarem essas formas estruturais em nosso território. 
Outro elemento fundamental é o tipo de atividade destinado aos países periféricos na divisão internacional do trabalho. Para tal afirmação Marini afirma que:

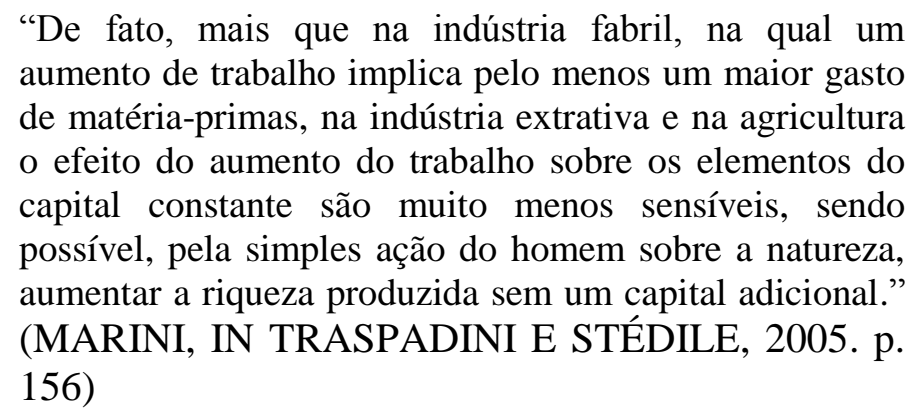

$\mathrm{O}$ autor nos afirma assim, que ao assumirmos a condição de economias agroexportadoras e mineiras geramos uma condição básica para a generalização dos mecanismos de aumento da massa de mais-valia expostos acima. $\mathrm{O}$ autor acrescenta que: "Em termos capitalistas, esses mecanismos (...) significa que o trabalho é remunerado abaixo de seu valor e correspondem, portanto, a uma superexploração do trabalho. (MARINI, IN TRASPADINI E STÉDILE, 2005. p. 157)

O conceito e o desvelamento dos processos que tornam a superexploração algo próprio da estrutura da dependência é um dos elementos centrais do aporte de Marini às teorias de interpretação da América Latina e ao marxismo de forma universal.

Assim, sustentamos que a superexploração, descrita por Marini, torna-se um elemento central na recomposição da taxa de lucro das burguesias internas, compensando a sua relação subordinada no mercado internacional e produz, da mesma forma, diferenças regionais importantes. Ou seja, quanto mais periférico for um território, maior será a superexploração do trabalho. Se de um lado o capitalismo brasileiro transfere riqueza aos países centrais, do outro produz a superexploração no seu interior e nos países mais periféricos que se relaciona.

\subsubsection{Subimperialismo}

Como já verificamos anteriormente não importava a burguesia brasileira nem o rompimento da dependência, nem um desenvolvimento autônomo diante o imperialismo. Para a classe dominante a principal preocupação era os níveis de lucro 
auferidos e, consequentemente seus problemas mais imediatos eram o de manter a superexploração e não possibilitar a queda de sua taxa de lucro.

Marini, discorrendo sobre a relação entre a burguesia brasileira e o imperialismo destaca que "o que estava em jogo para todos os setores da burguesia não era especificamente o desenvolvimento, nem o imperialismo, mas a taxa de lucros." (MARINI, 2012. p. 150) Nesse sentido, as ações da burguesia brasileira, após o primeiro período da industrialização, que não rompeu a dependência como previam os cepalinos, buscam apenas esse objetivo, por um lado com ações internas no território nacional para manter a superexploração em níveis que compensem suas taxas de lucros e, por outro, desenvolvendo ações em outros territórios.

Após o período de industrialização que se seguiu à era Vargas houve um amadurecimento do movimento operário no Brasil, com as contradições dadas pela modernização os sindicatos conseguiram altas nos salários que impactavam na taxa de lucro da burguesia interna. Marini afirma que:

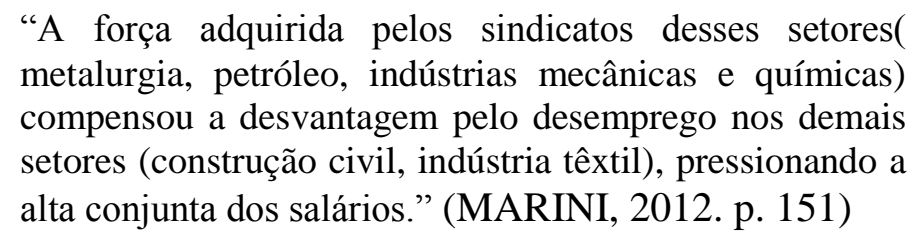

O autor está se referindo acima ao avanço da mão-de-obra qualificada em relação às indústrias menos tecnificadas, mas ressaltando que o poder da classe operária em impor derrotas a burguesia segue em ascenso.

Outro elemento que impactava na redução da taxa de lucro através da redução da superexploração é o "dinamismo que o movimento camponês ganhava” (MARINI, 2012. p. 151). Já discorreu-se sobre o processo de formação do campesinato no primeiro capitulo, mas é somente com seu amadurecimento como classe e sua organização política que se coloca como força na disputa política e nas disputas econômicas por mais direitos.

Marini sustenta que: “A solução imediata dada ao problema pela burguesia implicava a contenção coercitiva dos movimentos reivindicativos.” (MARINI, 2012. p. 151) Assim, o esforço desenvolvimentista que marcou o período que vai de Vargas até o início da década de 1960 e que, em partes, buscou um desenvolvimento mais autônomo 
do imperialismo, é deixado de lado para garantir a manutenção do sistema de exploração interna. O autor sustenta que: "Para a contenção salarial, a burguesia necessitava criar condições que não derivavam, evidentemente, da frente operárioburguesa que o governo e o PC insistiam em lhe propor.” (MARINI, 2012. p. 150)

A saída proposta pela burguesia brasileira, sustenta o autor, não passava por uma aliança nacional com os setores populares, estabeleceu assim um novo pacto com o imperialismo deixando de lado os objetivos vinculados a um possível desenvolvimento autônomo. Para manter o sistema estabelecido e marcar o alinhamento com o imperialismo estadunidense a burguesia utilizou-se da força militar e implantou uma ditadura, capaz de conter os avanços do movimento operário pela força e forçar os salários para baixo. Para Marini:

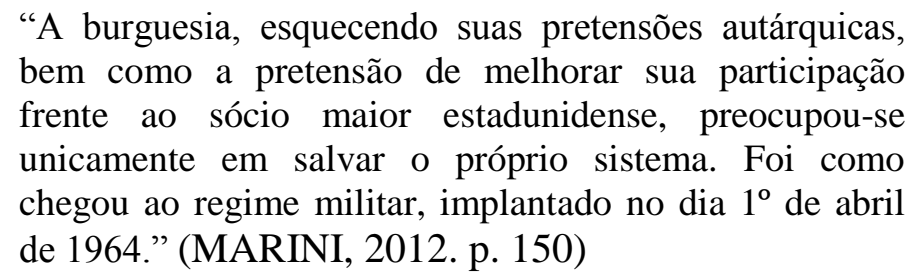

Para continuar lucrando a burguesia brasileira, através de seu governo ditatorial aliou-se ainda mais ao imperialismo estadunidense, vinculando o desenvolvimento industrial aos investimentos diretos do capital internacional. Marini afirma que " $o$ governo militar promove a integração acelerada da indústria nacional à estadunidense” (MARINI, 2012. p. 155). Mas para atrair esses investimentos foi necessário lançar mão de mecanismos de extração de lucro que se apresentassem mais compensatórios do que o investimento no centro capitalista.

Foi através do repasse de parte do valor obtido através da superexploração do trabalho diretamente para o capital internacional que a burguesia brasileira convenceu os sócios estadunidenses à investirem em nosso país. A manutenção de bons níveis de extração de valor dos trabalhadores, fortalecidos na luta política, só foi possível pelo uso da força e da repressão, mantendo assim os salários abaixo do valor real da força de trabalho. Sobre isso Marini é categórico:

"Para atrair os investidores estrangeiros, entretanto, o argumento principal esgrimido pelo governo foi a queda dos custos de produção no país, obtida através da contenção das reinvindicações da classe operária." (MARINI, 2012. p. 150) 
$\mathrm{O}$ autor afirma que a integração com o imperialismo produz um rápido desenvolvimento da indústria, porém gerando um efeito anacrônico ao desenvolvimento. Se por um lado aumenta-se exponencialmente a produção devido a entrada de novas tecnologias através do investimento externo, o mercado consumidor fica extremamente limitado devido aos baixos salários necessários a garantia do sobrelucro e ao desemprego causado pelas novas tecnologias. Sobre essa característica contraditória evidente na integração com o imperialismo Marini afirma que fica clara " $a$ tendência do capitalismo industrial brasileiro que o torna incapaz de criar mercados na proporção do seu desenvolvimento" (MARINI, 2012. p. 156) O autor prossegue sustentando que tal processo decorre do fato de que o Brasil "chega à etapa imperialista antes de ter conquistado a transformação global da economia nacional e em uma situação de dependência crescente frente ao imperialismo internacional" (MARINI, 2012. p. 150)

A contradição apresentada acima não é um fato exclusivo do Brasil, mas é próprio do sistema capitalista, porém, nos países centrais ela foi contida, segundo Marini, "pelo ajuste do processo tecnológico às condições próprias de seu mercado de trabalho e pela incorporação de mercados externos à suas economias." (MARINI, 2012. p. 156) Essa contradição impulsiona o capitalismo brasileiro na mesma direção, porém como o processo tecnológico, subordinado pela dependência, está sob controle direto do imperialismo e não nos marcos de um capitalismo nacional, a única saída possível é o avanço sobre mercados fora das fronteiras nacionais. É nesse sentido que desenvolve-se o avanço brasileiro em mercados no exterior, tendo o Paraguai como um exemplo clássico desse processo. Marini afirma que "no afã de compensar sua incapacidade de ampliar o mercado interno" o Brasil busca a "conquista de mercados já formados, principalmente na América Latina”. (MARINI, 2012. p. 156)

Sustenta-se por esse autor que a chegada do Brasil à fase imperialista sem o rompimento da dependência e a incapacidade da burguesia brasileira em competir por mercados já repartidos pelos monopólios imperialistas limita extremamente as possibilidades nessa busca por mercados. Assim, para a manutenção de suas taxas de lucro, afirma Marini, a burguesia brasileira propõe ao imperialismo "uma sociedade no próprio processo de produção no Brasil" e canaliza também o sobrelucro obtido através da exploração realizada nos outros países para seu sócio maior imperialista. $\mathrm{O}$ 
autor afirma assim a conformação de uma ação imperialista brasileira que se coloca como subimperialista, já que pela dependência continua condicionada pelo imperialismo. Marini afirma que: "Essa forma de imperialismo conduz, no entanto, a um subimperialismo." (MARINI, 2012. p. 157)

Desta forma, determinada pela dependência ao imperialismo a burguesia nacional intensifica o mecanismo da superexploração no seu território e o reproduz em territórios mais periféricos, notadamente no Paraguai, para, por um lado, compensar a redução de suas taxas de lucro e, por outro lado, proporcionar mais lucros aos sócios estadunidenses. Assim, “o subimperialismo brasileiro não pode converter a espoliação que pretende realizar no exterior em um fator de elevação do nível de vida interno". Tal elevação só seria possível com a ação de um "imperialismo independente" em que a superexploração promovida nos países mais periféricos pudessem alimentar a sanha da burguesia por lucros e possibilitar salários mais altos para a classe trabalhadora interna.

Desta forma, fundamenta-se que o desenvolvimento capitalista no Brasil nesse período, baseado numa aliança com o capital internacional, provocou, como saída para a manutenção dos lucros da burguesia interna e externa, por um lado a continuidade dos níveis de superexploração do trabalho através da coerção sobre o movimento operário e, por outro, a expansão, aliada ao centro capitalista, para mercados mais periféricos. É nesse contexto que aprofunda-se a relação de subordinação da economia paraguaia à brasileira, porém, sem deixar de apresentar alguns traços específicos na Questão Agrária.

A dominação da economia paraguaia em geral e de seu território em específico assume seu caráter subimperialista no marco das ditaduras militares nos dois países, trataremos esse ponto no capitulo seguinte. Aqui importa elucidar que pontos foram característicos da composição subimperialista brasileira em relação ao domínio da terra.

A ação desenvolvida pelo Brasil no Paraguai, além das questões já apresentadas anteriormente também assume traços específicos devido a composição de classes internamente no bloco dominante. Marini afirma que: "Para executar essa política antipopular, foi necessário reforçar a coalizão de classes dominantes" (MARINI, 2012. p. 154). O autor refere-se aqui as políticas de perseguições à lideranças, fechamento de sindicatos e especialmente ao arrocho salarial sobre grande parte da população 
brasileira. Assim, segue o autor, "a ditadura correspondeu a uma ratificação do compromisso de 1937 entre a burguesia e a oligarquia latifundiária-mercantil”. (MARINI, 2012. p. 154)

Devido a isso, para ter a força política necessária para conter pela força os níveis salariais, garantindo a superexploração, ou seja, rebaixando o nível de consumo e o nível de vida das massas trabalhadoras, a burguesia brasileira manteve e aprofundou o seu pacto com as oligarquias rurais. Marini sustenta que além da "necessidade do respaldo político do latifúndio" mais dois elementos foram fundamentais para a manutenção dessa aliança.

O período ditatorial foi precedido de um momento de crise para a burguesia industrial, por um lado, pela força que o movimento operário acumulava e, por outro, devido à um constante aumento dos preços dos produtos agrícolas. Esse aumento impactava diretamente nos custos para a burguesia industrial e, de certa forma, colocava em contradição a oligarquia agrária e a burguesia. Uma leitura rasa poderia apontar nessa contradição uma justificativa para uma aliança dos camponeses com a burguesia afim de realizar a Reforma Agrária. Porém, o rebaixamento dos salários realizado pela força na ditadura reduziu drasticamente a importância do custo dos produtos agrícolas para a realização de lucros pela burguesia. Mesmo com a ditadura militar, segundo Marini, exercendo um forte controle dos preços agrícolas "mantendo-os coercitivamente em um nível tolerável para a indústria” (MARINI, 2012. p. 154) essa contradição não se exacerbou. $\mathrm{O}$ autor afirma que: "A contenção salarial diminui, por um lado, o caráter
agudo que a alta dos preços agrícolas tinha para a
burguesia, posto que aqueles já não podem repercutir
normalmente sobre o custo da produção industrial."
(MARINI, 2012. p. 154)

O outro elemento, sustentado pelo autor como fundamental para manter a aliança da burguesia industrial com a oligarquia rural em sua pauta fundamental, que é a manutenção da estrutura de apropriação privada e monopólica da terra é, "o desinteresse relativo da grande burguesia em relação a uma efetiva dinamização do mercado interno brasileiro" (MARINI, 2012. p. 154). Se nos países centrais europeus o desenvolvimento do capitalismo representou um rompimento com as velhas estruturas, representadas pelo regime feudal, no Brasil, esclarece Marini: “ $O$ desenvolvimento 
industrial capitalista foi, na realidade, o que prolongou a vida do velho sistema semicolonial de exportação." (MARINI, 2012. p. 158) Já sustentamos durante todo o primeiro capitulo que a inserção do Brasil no mercado mundial deu-se, desde os primórdios da colonização, sob os marcos e determinações do capitalismo. Essa afirmação clareia a análise que contrapõe a ideia da existência de uma "burguesia nacional" com algum projeto autônomo para o capitalismo brasileiro. O autor acrescenta que o desenvolvimento do capitalismo brasileiro:

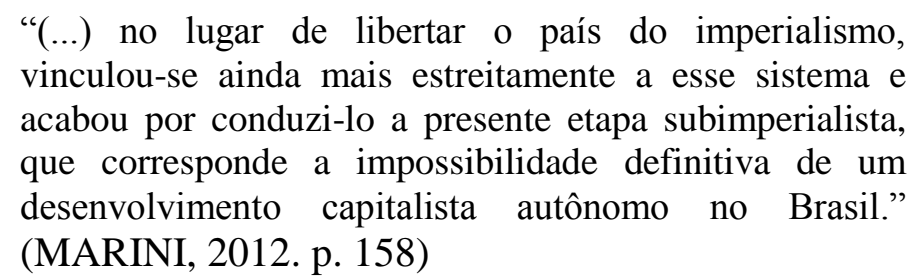

Um projeto de desenvolvimento autônomo do capitalismo brasileiro, como preconizava a CEPAL, baseava-se, além da industrialização, na realização da Reforma Agrária, que em decorrência, por um lado, criaria um enorme mercado consumidor interno para os produtos industriais e, por outro, ao aumentar a produção agrícola baixaria o preço das matérias-primas e dos alimentos aumentando a geração de excedente econômico. Porém "a burguesia renunciou a uma reforma agrária efetiva, que ferisse o atual regime de propriedade de terras", (MARINI, 2012. p. 154) mantendo a lógica de desenvolvimento do capitalismo dependente que dá característica ao subimperialismo brasileiro.

Assim, além das características descritas pelos intelectuais vinculados a Teoria Marxista da Dependência em geral, e por Marini, em especifico à ação subimperialista brasileira, reforça-se aqui os elementos que decorrem do desenvolvimento da questão agrária para a caracterização das ações subimperialistas do Brasil no território paraguaio. Dois elementos são fundamentais para a compreensão do desenrolar desse processo. O primeiro elemento trata da característica própria da função que o agrário assume no desenvolvimento do capitalismo brasileiro. Já discorreu-se sobre essa característica no capitulo anterior. Aqui trata-se de ampliar a sua decorrência no Paraguai.

Por um lado há a ação do capitalismo brasileiro, que em relação a terra atua com dois objetivos. O primeiro trata-se da expansão da exploração agrícola para o interior, incorporando essas terras à subordinação da agricultura à indústria. Nesse sentido o 
governo militar não realizou a Reforma Agrária, que alteraria a estrutura de posse e propriedade da terra, realizou e incentivou, em contraposição, a colonização do CentroOeste brasileiro e "se limitou à tentativa de criar melhores condições para o desenvolvimento agricola” (MARINI, 2012. p. 154).

A inserção de territórios periféricos a lógica capitalista segue as mesmas leis capitalistas descritas anteriormente quando apresentou-se o segredo da troca desigual. Se há uma transferência de valor entre as indústrias com menor composição orgânica para as indústrias com maior composição urbana, essa lei é a mesma que atua entre os países e, a mesma que atua em ramos diferentes da economia, nesse caso entre a agricultura e a indústria. Assim, a incorporação de territórios periféricos à economia capitalista, onde as relações de produção podem lançar mão de mecanismos como da superexploração e da utilização de formas de exploração do trabalho pré-capitalistas ${ }^{10}$, é uma tendência própria do sistema e, nesse caso, foi um importante mecanismo para recompor as taxas de lucro da burguesia industrial brasileira e seu sócio imperialista.

O segundo elemento é a força do movimento camponês. Já discorremos sobre a formação do campesinato brasileiro e o amadurecimento deste como classe até a década de 1960. As constantes tensões pela posse da terra não poderiam, nem com altos níveis de repressão, ficar sem respostas concretas de acesso a terra para os camponeses. Nesse sentido o governo militar promoveu três ações determinantes, a primeira, de menor escala e de forma extremamente pontual foi a realização de "expropriações para os casos críticos de conflito pela posse da terra" (MARINI, 2012. p. 154), a segunda foi a criação de inúmeros projetos de colonização, transpondo para as terras do centro-oeste e norte massas de camponeses sem terra oriundos do sul e do nordeste. A terceira ação foi a articulação com o regime ditatorial de Stroessner no Paraguai e, a promoção de um "grande projeto de colonização" naquele país. Trataremos desse terceiro elemento no Capitulo seguinte.

Assim a ação subimperialista brasileira em relação ao território paraguaio é movida, pela necessária incorporação de territórios periféricos à lógica de exploração capitalista como mecanismo de compensação da relação subordinada ao imperialismo

\footnotetext{
${ }^{10}$ Vide a utilização de trabalho escravo até os dias atuais. Assim pode-se afirmar que até o conceito "pré-capitalista" pode ser revisto, já que o capitalismo se apropria de todas as formas de exploração possíveis, utilizando-as conforme suas possibilidades e necessidades.
} 
no campo econômico e, para a solução de conflitos sociais pela posse da terra em seu território.

Por outro lado, na subordinação de territórios paraguaios ao subimperialismo brasileiro, há ação das classes dominantes paraguaias. Após a consolidação no poder no Paraguai de Alfredo Stroessner, em 1959, o governo daquele país iniciou "a colocar em prática um plano de modernização econômica." (WAGNER, 1990. p. 15)

Segundo o jornalista Carlos Wagner, que realizou uma grande pesquisa sobre a situação dos brasiguaios ${ }^{11}$, Stroessner iniciou seu plano de modernização, batizado de "Crescimento para Fora”, pois buscava "o aumento da presença paraguaia no mercado externo" (WAGNER, 1990. p. 14), pela agricultura, devido a sua importância na economia paraguaia. A forma de exploração agrícola dos camponeses paraguaios que em geral "ocupavam uma gleba de terra, faziam uma roça de sobrevivência e exploravam a erva-mate nas florestas" (WAGNER, 1990. p. 14) não se adequava aos planos de modernização da classe dominante paraguaia. Wagner afirma que:

"Este esquema de produção não era adequado aos planos econômicos de Stroessner para a região, cuja palavra de ordem era modernizar, através da mecanização em alta escala, a produção.” (WAGNER, 1990. p. 14)

Além da forma de produção utilizada pelos camponeses paraguaios, a classe dominante marcadamente branca e racista, considerava-os "indolentes para o pesado serviço” (WAGNER, 1990. p. 14). Assim, nos afirma Wagner: “O governo Stroessner confiou às grandes colonizadoras brasileiras, norte-americanas, alemãs e japonesas a tarefa de organizar a colonização.” (WAGNER, 1990. p. 14).

Dessa forma, a ação subimperialista brasileira de domínio dos territórios agrícolas paraguaios não poderia chegar ao seu pleno êxito sem o apoio da classe dominante local. Mais que isso, a subordinação ao subimperialismo brasileiro e ao imperialismo norte-americano era parte fundante do modelo de desenvolvimento proposto pela burguesia paraguaia.

\footnotetext{
${ }^{11}$ O termo brasiguaio surgiu em uma reunião que aconteceu em 1985 entre lideranças de camponeses sem terras oriundos do Paraguai com o então deputado federal pelo Mato Grosso do Sul, Sérgio Cruz, do Partido dos Trabalhadores (PT), na cidade de Mundo Novo - MS. Essa reunião fez parte do processo que culminou com o retorno de 950 famílias de camponeses que viviam no Paraguai para o Brasil.
} 
Observa-se que o desenvolvimento específico do capitalismo brasileiro e a conformação da dependência desenvolveram condições que levaram a determinados limites ao próprio desenvolvimento. As saídas propostas nas teses cepalinas mostraramse limitadas em resolver as questões que se colocaram para a superação do subdesenvolvimento.

Conforme apresentamos, a superação da dependência, por ser um processo próprio do sistema capitalista nos países periféricos, só pode ser conquistada através da superação do sistema capitalista como tal. Nesse sentido concordam Marini e os demais intelectuais da Teoria Marxista da Dependência, a superação só poderá ser conquistada com uma Revolução Social, que subverta a ordem capitalista existente. Nisso concorda também Creydt em relação ao Paraguai, para o qual somente uma "alianza obrerocampesina será el corazón de la nación revolucionária” (CREYDT, 2010. p. 117) que conquistará a libertação do jugo imperialista estadunidense e subimperialista brasileiro com o fim da dependência.

Não foi essa a resposta dada a dependência, nem pela burguesia brasileira, nem pela burguesia paraguaia. A resposta dada foi a de aumentar a exploração sobre as massas de trabalhadores internamente, aumentar o saque aos recursos naturais e conformar-se em ser o sócio minoritário do imperialismo estadunidense.

Essa forma de inserção dependente no mercado mundial, as características agrárias das economias brasileira e especialmente paraguaia e, a opção das burguesias brasileira e paraguaia em manter-se na condição de sócios minoritários do imperialismo engendrou a dominação do território como um importante mecanismo de compensação.

A nova fase que assume o capitalismo mundial sobre a hegemonia do Capital Financeiro Especulativo reafirma a apropriação de rendas de monopólio como forma de valorização do capital e a renda da terra é fundamental nesse processo. A burguesia brasileira tende a avançar na apropriação e privatização de territórios internamente e a manter o seu domínio sobre vastas extensões do território paraguaio, aumentando por um lado, a parte da mais-valia que se apropria na forma de renda da terra e, por outro, oferecendo maiores lucros ao sócio maior imperialista em troca de investimentos e do equilíbrio econômico. Seguiremos nesse ponto no próximo capitulo. 


\section{DOMÍNIO ECONOMICO E APROPRIAÇÃO DAS TERRAS DO PARAGUAI PELO CAPITAL BRASILEIRO}

O processo de expansão brasileira sobre os territórios paraguaios remonta ainda ao período colonial, onde a ação de bandeirantes no território que hoje é paraguaio ampliou as fronteiras do então império português. Esse período, conforme já apresentou-se nos capítulos anteriores coincide com a expansão do Capital Mercantil. Pode-se afirmar que a invasão de territórios paraguaios faz parte do mesmo processo de ocupação do interior do Brasil com o objetivo de saque e apropriação de riquezas naturais como forma de aumento da quantidade de mercadorias, consequentemente mais lucro mercantil.

Com a Guerra do Paraguai, também denominada Guerra da Tríplice Aliança no período que compreende 1865 à 1870, o capital brasileiro aliado ao estadunidense se expande com maior força sobre o Paraguai controlando grandes extensões de terra. É nesse momento que se inicia segundo o grande intelectual e militante comunista Oscar Adalberto Federico Creydt o período de re-colonização do país (CREYDT, 2007). Nesse período configura-se a estrutura fundiária paraguaia baseada no latifúndio agroexportador com forte domínio dos capitais estrangeiros, em especial o brasileiro. Dialogando com os capítulos anteriores e como pressuposto da análise aqui proposta coincide nesse momento a expansão do Capital Industrial e a sua ascensão hegemônica na Inglaterra e seu rápido desenvolvimento nos Estados Unidos.

Com o ascenso brasileiro à fase Subimperialista, a industrialização da agricultura e a articulação entre as ditaduras militares nos anos 60 e 70 verifica-se um novo avanço dos capitais brasileiros sobre a economia paraguaia, aumentando o território explorado e promovendo um ajuste modernizante com a incorporação do monocultivo extensivo como a base fundamental de exploração das terras (VUYK, 2013). Nesse contexto é fundamental a ação do Brasil em geral e, no período de conformação do Subimperialismo em especifico, na dominação e organização da posse e propriedade da terra no Paraguai.

O desenvolvimento do capitalismo no Brasil e as contradições internas desse desenvolvimento geraram condições históricas para expansão dos seus capitais para o 
Paraguai e fundamentam a compreensão da determinação brasileira na forma de apropriação das terras e de organização da produção agrícola naquele país.

Para a compreensão desse fenômeno na atualidade é importante trazermos a luz um elemento atual no desenvolvimento do Capitalismo em geral e sua determinação no campo em específico. A ascensão do Capital Financeiro como hegemônico no Mercado Mundial promoveu mudanças importantes no processo de apropriação dos territórios e juntamente com as características históricas da Questão Agrária e da inserção subordinada dos países periféricos, fundamentam os elementos centrais do atual estágio de apropriação de territórios no Brasil e sua determinação no Paraguai. 


\subsection{Hegemonia do Capital Financeiro na Agricultura - Economia do}

Agronegócio

Para a compreensão do papel determinante que o subimperialismo brasileiro desempenha na apropriação de territórios no Paraguai e quais as características são desenvolvidas no período atual é importante complementar com a atualidade os capítulos anteriores. Ou seja, qual a característica fundamental assume a apropriação da terra e a organização da produção agrícola no Brasil e, como apresenta-se a inserção da economia brasileira no mercado mundial atualmente.

O período atual caracteriza-se por uma re-primarização da economia brasileira, esse processo, afirma Delgado, inicia-se ainda no segundo governo de Fernando Henrique Cardoso (1998-2002) e segue até os dias atuais. O autor afirma que FHC busca adotar uma política que vise "gerar saldos de comércio exterior a qualquer custo, tendo em vista suprir o déficit da Conta Corrente." (DELGADO, 2012. p. 93)

No decorrer das ultimas décadas, visualiza-se o advento do agronegócio como a forma de organização do capital na agricultura brasileira. Ele encerra em si uma articulação do latifundiário proprietário de terras com as transnacionais que monopolizam o mercado de insumos e commodities. É esse setor, segundo Delgado que será escalado para gerar os saldos necessários na balança comercial brasileira, o autor afirma que: "Nesse contexto, a agricultura capitalista, autodenominada de agronegócio, volta às prioridades da agenda da política macroeconômica externa e da política agrícola interna” (DELGADO, 2012. p. 93).

A expansão das exportações de produtos primários levou à um aumento considerável do preço das terras. Já vimos nos capítulos anteriores que o preço da terra está diretamente vinculado a Renda da Terra, tal seja, a parte da mais-valia que o proprietário de terras se apropria pelo simples fato de ser proprietário privado das terras. Delgado afirma que o aumento da "exportação de produtos primários, suporta um processo intenso de valorização das terras agropecuárias” (DELGADO, 2012. p. 97).

Como a inserção do Brasil no Mercado Mundial continua a dar-se de maneira dependente, através da importação de tecnologias para a produção agrícola e da exportação de produtos com baixa composição orgânica do capital, o que verifica-se é a continuidade do processo de transferência de valor já descrito anteriormente. 
Dessa forma, para compensar a transferência de valor realizada para os países centrais, no mercado agrícola representados pelas grandes transnacionais e pelos bancos, a burguesia agrária brasileira recompõe a sua taxa de lucro através da apropriação da Renda da Terra e do aumento da Superexploração do trabalho.

Delgado afirma que:

"O que fica evidente nos anos 2000 é o relançamento de alguns complexos agroindustriais, da grande propriedade fundiária e de determinadas políticas de Estado, tornado viável um peculiar projeto de acumulação de capital, para o qual é essencial a captura da renda da terra, juntamente com a lucratividade do conjunto dos capitais consorciados no agronegócio." (DELGADO, 2012. p. 109).

O autor ao falar de um peculiar projeto de acumulação de capital, já aponta um projeto que é específico dos países periféricos e que só é possível lançando mão de alguns processos que são característicos desses países. A subordinação econômica e, a transferência de valores realizadas no mercado internacional através dos mecanismos já apresentados, condicionam a burguesia agrária brasileira a buscar outras formas de recompor a sua taxa de lucro. Na passagem anterior o autor já apresenta o elemento central que sustenta a afirmação desse trabalho, ou seja, para a conformação desse modelo de exploração o elemento central é a apropriação da Renda da Terra.

Delgado, discorrendo sobre o padrão de exploração da economia do agronegócio aponta que apresenta-se uma dupla superexploração. Não é necessário retornarmos esse tema para afirmar a superexploração como uma das formas peculiares das burguesias internas compensar a sua relação subordinada no mercado mundial, porém, o que é mais importante aqui é no que tange a superexploração dos recursos naturais.

Apenas exemplifiquemos o emprego da superexploração do trabalho na agricultura, seja através do aumento da intensidade do trabalho, seja através da transferência dos gastos com a reposição da força de trabalho para o Estado. Delgado afirma que:

"Não é novidade que o ritmo e as jornadas de trabalho impostas aos trabalhadores da cana, pelas metas de produção que se lhes impõe - 10 à 12 toneladas de corte de cana ao dia implicam em milhares de movimentos individuais de flexão, aplicação de força física no corte e 
ajuntamento da cana. Essas condições de produção provocam, em ultima instância, doenças osteomusculares praticamente certas com o passar do tempo." (DELGADO, 2012. p. 126).

$\mathrm{O}$ autor segue afirmando que "a transferência do ônus da superexploração do trabalho para o INSS" (DELGADO, 2012. p. 126), caracteriza exatamente que o capitalista expropria parte do trabalho necessário para o trabalhador repor a sua força de trabalho. Nesse contexto, o atual estágio de desenvolvimento do capitalismo no campo, organizado sob a égide do capital financeiro com o nome de agronegócio, aprofunda e torna sistemático a utilização da superexploração do trabalho.

Delgado, tratando do aumento da exploração sobre o meio ambiente, cita três mecanismos de aumentar a extração de excedente econômico dos recursos naturais. $\mathrm{O}$ primeiro deles relaciona-se a "violação sistemática da norma ambiental-florestal exigida sobre limites da Área de Reserva Legal (RL) (florestal) e Área de Preservação Permanente (APP) (mata ciliar e topos e encostas de morros)" (DELGADO, 2012. p. 117).

O segundo ponto apresentado pelo autor é "o aumento das queimadas $e$ desmatamentos" (DELGADO, 2012. p. 118), notadamente conjunto com a invasão e saque de Unidades de Conservação (UC’s) e Territórios Indígenas (TI's).

Sobre esses dois aspectos, Zavaski, estudando a pauta da Bancada Ruralista no Congresso Nacional Brasileiro já aponta que:

"Devido à transferência de riqueza da burguesia agrária
brasileira para as corporações internacionais no processo
de circulação do capital, seja pela diferença de
composição orgânica, seja pela imposição de preços de
monopólios, a apropriação da Renda da Terra é
fundamental para essa fração da burguesia."
(ZAVASKI, 2012, p. 20)

$\mathrm{O}$ autor segue afirmando que:

"Assim, a burguesia agrária brasileira, através de sua bancada no Congresso Nacional, propõe um conjunto de ações que visam basicamente o aumento da exploração sobre os trabalhadores, mas sobretudo a expansão do território de exploração.” (ZAVASKI, 2012, p. 20)

Para chegar à essa conclusão, o autor, investigando as pautas colocadas pela Bancada Ruralista, que são em síntese o criação de marcos jurídicos e a legitimação do 
Programa Político da burguesia agrária brasileira, verificou que a maioria das ações, sejam no âmbito do legislativo, seja na pressão sobre o executivo visam o aumento do território de exploração.

A primeira ação proposta nos marcos da legislatura de 2012-2014 foi a reformulação do Código Florestal. Tal alteração aumentou a área de exploração em mais de 79 milhões de hectares, segundo dados do IPEA em seu Comunicado $n^{\circ} 96$ de junho de 2011. A segunda ação realizada nesse âmbito, que na realidade fazem parte de um conjunto de proposições legislativas, relaciona-se com os Territórios Indígenas e as Unidades de Conservação, esses Territórios representam 279.746.824 ha e 851.487.700 ha respectivamente e sofrem, além de processos de exploração ilegais, diversas ações dos ruralistas para alterarem os marcos jurídicos que os regulamentam, possibilitando a exploração capitalista desses territórios. Uma terceira e importante ação é a que se relaciona com a regulamentação da aquisição de terras por estrangeiros. Zavaski afirma que: "o próprio capital internacional tem buscado apropriar-se diretamente dos territórios, para que a renda da terra venha a ser também parte da substância do seu lucro" (ZAVASKI, 2012, p. 20).

Além dessas ações no campo legislativo é constante as tentativas de privatização dos territórios da Reforma Agrária, segundo dados do INCRA, o território ocupado por assentamentos rurais aproxima-se de 100 milhões de hectares.

Não objetiva-se aprofundarmos as ações desenvolvidas pela burguesia agrária brasileira para ampliar a área de exploração, apenas exemplificando a abrangência dela e sua causa fundamental, a compensação de sua taxa de lucro através da apropriação da Renda da Terra.

Delgado afirma que esse modelo de apropriação do território e organização da produção agrícola "constituem a configuração de uma estratégia estatal-privada de acumulação de capital, que de certa forma conformam o próprio padrão de crescimento econômico perseguido nesta década pelo agronegócio” (DELGADO, 2012. p. 127).

O autor prossegue afirmando que o conjunto de características do agronegócio, com a superexploração do trabalho e a apropriação privada dos recursos naturais fazem parte de um pacto, que é denominado "economia política do agronegócio". 
Assim, Delgado afirma que :

\begin{abstract}
"a inserção primária no comércio exterior; as relações de dependência subjacentes de tal inserção, expressas na Conta Corrente do Balanço de Pagamento; a exacerbada valorização da renda fundiária neste processo e as pressões coetâneas por superexploração de recursos naturais e do trabalho humano são fatos históricos que se integram num todo articulado." (DELGADO, 2012. p. 127).
\end{abstract}

O autor afirma que os recursos naturais, representados nas terras, na extração mineral e na hidroeletricidade são os setores que mais crescem na economia brasileira. Segundo Delgado: “Todos esses ramos produtivos operam com base em monopólio de recursos naturais, que nas suas dotações originais independem de investimentos ou da aplicação do trabalho humano para produzi-los." (DELGADO, 2012. p. 127).

Pela sua condição de monopólio, todos esses ramos econômicos produzem rendas. Essas rendas fundiárias, derivadas do monopólio privado desses recursos "são objeto de ávida disputa no processo de apropriação da renda e da riqueza social". (DELGADO, 2012. p. 127)

O autor reforça que: "Dada a atual configuração da inserção do Brasil no comércio mundial, os recursos naturais passaram a figurar como vetor principal de competitividade externa." (DELGADO, 2012. p. 127)

Como o domínio subimperialista brasileiro sobre a economia paraguaia foi fundamentado exatamente sobre esses ramos produtivos, notadamente o agronegócio e a hidroeletricidade, o atual estágio de desenvolvimento capitalista no campo brasileiro é determinante no processo de apropriação das terras e de organização da produção agrícola no Paraguai. 


\subsection{Consolidação da Hegemonia Brasileira e Apropriação das Terras no Paraguai}

A expansão brasileira sobre o território paraguaio remonta ao período colonial, ainda antes da consolidação do que viria a ser o Brasil e mesmo o Paraguai. Nesse período os bandeirantes em busca de minérios e da exploração escrava ou servil da mãode-obra dos povos que ocupavam essas terras, notadamente os guaranis, realizaram inúmeras incursões consolidando povoações e expulsando esses povos cada vez mais sertão adentro. A utilização de divisões internas e conflitos entre os povos dessa região foram, além das armas e das doenças, elementos importantes para a consolidação do domínio português sobre largas parcelas do então território guarani.

Um fato marcante para exemplificar esse período foi a aliança dos portugueses com os índios guaicurus kadwell, os conhecidos índios cavaleiros das planícies pantaneiras, essa foi uma das principais derrotas e perdas territoriais dos guaranis, consolidando como português os território que hoje compõe parte considerável do estado do Mato Grosso do Sul, que terá sua formação atual completada com as incorporações feitas após a Guerra do Paraguai.

Outro fato relevante dessa expansão é a expulsão dos Missionários Jesuítas do império português, esse processo resultou na expulsão e genocídio dos guaranis nas conhecidas Missões, seguido de uma expansão territorial e incorporação desses territórios ao Brasil. A ocupação do território paraguaio por brasileiros teve um importante impulso com a Guerra da Tríplice Aliança, no período de 1865 a 1970.

O Paraguai foi até esse período o país que havia conseguido desenvolver um projeto de desenvolvimento nacional mais ou menos autônomo e que, evidenciava características possíveis de torná-lo uma potência hegemônica na América do Sul. Sobre isso Creydt afirma que: “En el Paraguay se estaba operando un rápido processo de desenvolvimiento nacional independiente, sobre las bases echadas por la ditadura revolucionária de Francia."'(CREYDT, 2010. p. 101) Porém isso contrariava os interesses das classes dominantes da vizinhança e, principalmente, da burguesia inglesa e estadunidense. Nesse sentido Creydt caracterizará a guerra como o início da recolonização do país (CREYDT, 2010. p. 104), pois contém esse caminho autônomo e subjuga a economia paraguaia aos interesses do capitalismo central e das burguesias brasileira e argentina. 
Creydt descreve os interesses do Brasil e da Argentina e seu financiamento pela Inglaterra nas seguintes passagens:

"El império del Brasil dicidió aprovechar su nueva alianza con Buenos Aires para destruir el Estado nacional paraguayo e resolver de esta manera el viejo problema de fronteras creado por los avances de los portugueses." (CREYDT, 2010. p. 102)

Na passagem acima o autor apresenta o interesse principal do Brasil como sendo a consolidação do domínio territorial, ou seja, a anexação de parte do território paraguaio ao Império Brasileiro. A anexação econômica se dará na fase seguinte numa aliança entre a burguesia subimperialista brasileira e a ditadura militar de Stroessner.

O autor prossegue:

"Las clases dominanes de Buenos Aires vieron en la guerra contra el Estado nacional paraguayo un médio de dominar las províncias argentinas definitivamente y abrir um gran mercado al capitalismo británico. Los banqueiros de Londres se encargaron de financiar la empresa de abrir el Paraguay a sangre y fuego" (CREYDT, 2010. p. 102)

O autor afirma ainda que a monarquia brasileira estava sob o comando dos latifundiários produtores de açúcar que "por interés de clase, necessitaban consolidar y prestigiar al Estado monárquico llevando la guerra adelante” (CREYDT, 2010. p. 102). A classe hegemônica argentina por sua vez, afirma Creydt, era formada por uma burguesia importadora e exportadora "que con frases liberales servía a una aristocracia de grandes latifundistas y al capital inglês". (CREYDT, 2010. p. 102)

$\mathrm{O}$ autor segue afirmando que: "Entre la monarquia liberal del Brasil y la república del Plata no existia una diferencia essencial”. (CREYDT, 2010. p. 102) Assim, o Brasil e a Argentina, financiados pela Inglaterra, tinham o objetivo central de destruir o Estado nacional paraguaio. Após cinco anos de guerra, esmagaram a jovem nação paraguaia, porém, a "Triple Alianza fue incapaz de destruir el Estado nacional sin destruir fisicamente a la nación misma”. (CREYDT, 2010. p. 103)

Com a derrota paraguaia na guerra houve uma grande perda territorial do país, regiões inteiras foram anexadas ao Brasil e outras à Argentina. Além disso, amplia-se o território formalmente paraguaio sobre domínio de brasileiros, ou seja, parcelas de terra 
dentro do território nacional porém sobre posse e propriedade de estrangeiros. Acerca desse período Vuyk afirma que:

“(...)capitales argentinos -aliados a los capitales inglesesy brasileros -aliados a los norteamericanos- se expanden sobre Paraguay, controlando grandes extensiones de tierra y otros recursos naturales, como los bosques." (VUYK, 2013).

A autora prossegue afirmando também que são nesse período que se consolidam os principais partidos latifundiários do Paraguai, surgido de uma aliança dos caudilhos nacionais, chamados por Creydt como "famílias traidoras", com os capitais estrangeiros. Essa hegemonia política com bases internas no latifúndio e externas nos capitais estrangeiros é um dos elementos fundamentais que resulta na situação agrária atual do país, por um lado um grande número de camponeses sem terra e, por outro cerca de $20 \%$ das terras sob propriedade de estrangeiros, sendo essas as mais agricultáveis e bem localizadas.

Creydt afirma que "el sistema económico-social creado por la revolución nacional fue reenplazado por el sistema econômico social imperante en los países vencedores." (CREYDT, 2007. p. 104)

Esse autor, confirmando a influência da hegemonia do Capital Mercantil na determinação da forma de apropriação do território e da organização da produção agrícola afirma que, a partir da hegemonia brasileira aliada ao imperialismo:

"La estancia latifundista e ganadera orientada hacia la exportación y la explotación florestal latifundista exportadora de matérias primas se convertieron em los sectores fundamentales de la economia." (CREYDT, 2007. p. 104)

A afirmação realizada pelo autor sustenta a hipótese de que o desenvolvimento do capitalismo no campo brasileiro e a forma de inserção no mercado mundial é determinante no próprio processo de desenvolvimento e na apropriação da terra no Paraguai. A aliança para a apropriação das terras e dos recursos naturais paraguaios sob a hegemonia brasileira busca nesse período o aumento das mercadorias exportadas, numa determinação já apresentada nos capítulos anteriores de hegemonia do Capital Mercantil. Essa aliança, segundo Creydt, juntou os "grandes partidos latifundistas y 
grandes capitalistas, al servicio del imperialismo y de las clases dominantes de la Argentina y del Brasil”. (CREYDT, 2007. p. 105)

No que refere-se a forma de apropriação do território paraguaio, determinado pela hegemonia brasileira sob a égide do Capital Mercantil, resultou em um processo de concentração de terras nas mãos dos latifundiários paraguaios, brasileiros e argentinos. Creydt, afirma que o que se viu foi: "Uma reforma agraria retrógrada despojó al Estado de la mayor parte de sus tierras al mismo tempo que expropió a la mayor parte de los campesinos." (CREYDT, 2007. p. 104) Assim, o período que se segue ao pósguerra, caracteriza-se pela hegemonia do Brasil no processo de dominação econômica do Paraguai.

As colônias espanholas desenvolveram a sua forma de exploração baseada na organização das "haciendas coloniais", sobre a base do trabalho servil e da apropriação de formas de exploração já presentes entre os povos originários. Na hacienda colonial, havia uma forma de organização que fortalecia o mercado interno, semelhante à organização de um feudo. O Brasil ainda no período colonial desenvolveu certa infraestrutura devido a forma de organização de sua exploração como colônia, que já foi tratado no primeiro capitulo. A organização da plantation, cujas bases eram: a alta tecnologia, especialização e voltada para o mercado externo, ao contrário da hacienda colonial espanhola, possibilitou o desenvolvimento de uma considerável infraestrutura de produção primária e exportadora.

Essa infraestrutura desenvolvida no período colonial será a base para a anexação econômica do Paraguai realizada com a vitória da Tríplice Aliança e a destruição do projeto de desenvolvimento nacional desenvolvido pós "Revolución de 1811 " naquele país.

É com essa base que o Brasil irá se industrializar a partir dos anos 20, dentro dos marcos da expansão imperialista do centro capitalista e das contradições interimperialistas que resultaram nas duas Guerras Mundiais. Com a política de substituição de importações o Brasil chegará aos anos 50 com uma indústria de base fortalecida e uma indústria manufatureira consolidada. Porém, a necessidade dos recursos oriundos das exportações agrícolas para o financiamento desse desenvolvimento e a aliança com o capital internacional tanto para o financiamento quanto para a disposição de 
tecnologia colocarão dois elementos fundamentais para a compreensão das características expansionistas assumidas pelo Brasil em relação aos países da periferia. Esses dois pontos foram caracterizados nos capítulos 1 e 2 desse trabalho, aqui sendo apenas ressaltados.

A primeira característica é a manutenção da classe latifundiária como parte do bloco hegemônico, mantendo-se a forma de exploração da terra, a exclusão dos camponeses no acesso e, a relação entre latifúndio e poder político. A segunda característica é o desenvolvimento dependente da economia brasileira, promovendo uma constante transferência de riqueza para os centros capitalistas devido a sua inserção subordinada no mercado internacional.

O desenvolvimento industrial baseado na substituição de importações e com tais características levou a duas contradições importantes que levaram o Brasil ao desenvolvimento de uma política expansionista tanto em relação ao domínio econômico, como, no caso do Paraguai na ocupação de territórios com colonos brasileiros.

A aliança entre a nascente burguesia industrial e a classe latifundiária gerou uma das contradições fundamentais para a política expansionista brasileira. O domínio da terra pelos latifundiários e a não incorporação da Reforma Agrária como parte do programa de desenvolvimento em curso ocasionou um limite estreito à política de substituição de importações, devido ao limitado mercado interno e a não conformação de uma massa de camponeses como consumidores de manufaturas. Esse limitado mercado interno logo se transformou num entrave na economia brasileira, podendo ser superado apenas com a realização da Reforma Agrária, criando um mercado de massas formado pelos camponeses ou, dominando mercados consumidores externos. A opção da nascente burguesia industrial foi a de se manter aliada aos latifundiários e promover a chamada modernização conservadora, mantendo-se as bases agrárias do campo brasileiro com o latifúndio e a produção voltada à exportação.

Além desse limite ao próprio desenvolvimento industrial provocado pela aliança com os latifundiários, a não realização da Reforma Agrária produziu uma massa de camponeses despossuídos que explodiam em movimentos de luta pela terra cuja maior expressão no período de industrialização foi as Ligas Camponesas. A modernização 
conservadora promoveu uma exclusão ainda maior de massas camponesas devido à industrialização da agricultura, a demanda por terra começou a ser uma pauta incorporada pelos movimentos de esquerda e um elemento central na disputa política no Brasil. Somente a repressão já não conteria os camponeses, foi necessária uma resolução parcial do problema da terra através da colonização dos sertões brasileiros do norte e centro-oeste, colonização essa que ultrapassou as fronteiras formais do Brasil.

Já afirmou-se anteriormente que o desenvolvimento dependente, baseado na importação de capitais e no domínio tecnológico do centro capitalista desenvolveu uma economia dependente, com constante transferência de riquezas para o centro capitalista.

Além de lançar mão do mecanismo da superexploração do trabalho para compensar as suas perdas a burguesia brasileira promove a reprodução da lógica de transferência de riqueza entre países da periferia para países do centro. Essa reprodução é feita entre centros da periferia com regiões e países mais periféricos, a esse processo Marini caracterizou como subimperialismo. O Brasil mantendo-se como uma economia dependente chega a sua fase subimperialista na década de 1960.

Já vimos no segundo capitulo os elementos teóricos-históricos que caracterizam essa processo. Assim, a expansão dos capitais e monopólios brasileiros é necessária para evitar a queda da taxa de lucro provocada pela transferência de riqueza para os centros capitalistas e pelo limitado mercado interno. Além disso, apresenta-se como uma saída para solucionar os conflitos de classe e intra-classe que essas características explicitam.

A luta pela terra empreendida pelos camponeses sem terra experimenta cada vez mais níveis avançados de organização e unidade, em 1961 realiza-se o I Congresso camponês onde as diversas organizações se unificam sob a consigna "Reforma Agrária na lei ou na marra". O fortalecimento da pauta dos camponeses provoca fissuras na classe dominante, parte da burguesia industrial titubeia em suas posições provocando um conflito com os latifundiários. A expansão capitalista brasileira sobre os países mais periféricos e, no caso paraguaio, a ocupação de suas terras por brasileiros apresenta-se como uma saída para a manutenção do bloco burguês-latifundiário no Brasil.

O subimperialismo brasileiro desenvolveu-se na região em cooperação antagônica com o imperialismo estadunidense, embora se constitua numa importante 
base de expansão dos capitais do norte, disputa com esses a taxa de lucro e desenvolve uma política de expansão por vezes contraria ao centro imperialista.

A ação subimperialista brasileira no Paraguai, dá prosseguimento à um processo de anexação territorial e econômica, conforme retratamos anteriormente. O mecanismo político que garantiu, por um lado, os interesses dos capitais brasileiros e, por outro, os interesses da classes dominantes paraguaias foi a articulação entre as ditaduras militares dos dois países. Já vimos anteriormente, que a ditadura brasileira foi necessária para a redução, pela força, do valor da força de trabalho internamente, possibilitando a superexploração. A articulação entre as ditaduras brasileiras é paraguaia foi necessária, por sua vez, para possibilitar o subimperialismo.

Podemos afirmar que a articulação entre as ditaduras brasileiras e paraguaias, não consiste num fato isolado e se insere no marco de dominação econômica e política que se segue desde o final da Guerra da Tríplice Aliança, com a formação dos Partidos Colorado e Liberal no Paraguai selando a aliança entre a classe dominante nativa com os capitais e interesses das classes dominantes brasileiras.

Ainda na década de 40 amplia-se a cooperação militar com o Paraguai afirmando a hegemonia brasileira sobre o comando das forças armadas paraguaias, Vuyk afirma que essa cooperação dava-se:

“ (...)principalmente en la formación de altos cargos militares paraguayos en la Escuela Superior de Guerra del Brasil -centro de la estrategia de expansión imperialista brasilera-, como el caso del dictador paraguayo Alfredo Stroessner." (VUYK, 2013)

Porém é no período das ditaduras militares onde há o completo alinhamento e subordinação da economia do Paraguai ao eixo do subimperialismo brasileiro em cooperação antagônica com o imperialismo estadunidense. Retomando o conceito tratado no segundo capítulo, o Subimperialismo:

“(...) constituiria na exploração de um país dependente mais desenvolvido sobre outros menos desenvolvidos, em busca de controle de parte substancial de seus mercados, através não apenas de exportações, mas, sobretudo, de investimentos em setores econômicos básicos." (BAMBIRRA, 2012, p. 218) 
Dois setores são fundamentalmente importantes para a aliança subimperialista brasileira, e, que atualmente, conforme vimos no inicio deste capítulo assumirá peculiar importância. O setor relacionado aos recursos naturais e à agricultura, assim dois elementos são marcantes na ação subimperialista brasileira no Paraguai, a dominação e subordinação da forma de apropriação e organização da produção agrícola e a produção de energia através da hidroeletricidade.

A assinatura do Tratado Binacional de Itaipu em 1973, realizado pelas ditaduras militares brasileira (1964-1985) e paraguaia (1954-1989) consolida a aliança entre as classes dominantes, aprofunda a exportação de capitais brasileiros para o Paraguai e o controle dos monopólios brasileiros sobre as matérias primas centrais como a energia e as terras, além de controlar setores importantes do mercado externo paraguaio, como o de grãos e energia. A construção de Itaipu é um exemplo claro da conformação do subimperialismo brasileiro e sua cooperação antagônica com o imperialismo norteamericano. Creydt é taxativo ao afirmar que:

"La demanda de energia necesária para la producción industrial de las grandes siderúrgicas y en especial, para la producción de alumínio, obligó al Brasil a la construcción de la gran represa hidroelétrica de Itaipú, financiada con capitales norteamericanos, y a la imposición al Paraguay del Tratado antinacional de Itaipú, em 1973." (CREYDT, 2007. p. 109)

O projeto de desenvolvimento associado dependente (VUYK, 2012.) do Paraguai irá abrir ao subimperialismo brasileiro alinhado ao imperialismo estadunidense a possibilidade de estruturar e reorganizar a dominação sobre o território paraguaio. Nesse período as terras mais produtivas desse país são reorganizadas para a produção de grãos para a exportação, a estrutura do latifúndio de criação de gado formada no pósguerra é substituída pela agricultura baseada no monocultivo, especialmente da soja, no capital transnacional e no latifúndio.

A ditadura militar brasileira foi essencial para a classe dominante realizar os ajustes necessários para a fase subimperialista do capitalismo no Brasil. A custa de mais alinhamento ao imperialismo o Brasil ampliou a formação de monopólios, a industrialização associada e experimentou um período de crescimento econômico que possibilitou à burguesia industrial aumentar a sua taxa de lucro e manter-se aliada aos latifundiários. Isso relegou mais uma vez a Reforma Agrária para fora do programa de 
desenvolvimento do país. Aos camponeses sem terra restaram por um lado a forte repressão através de prisões, mortes e o exílio e por outro a migração rumo à fronteira agrícola do país. O processo de migração foi largamente incentivado pelos militares e a ocupação do centro-oeste e norte do país se inseria nas diretrizes de segurança nacional, no discurso de povoar para não perder. Porém logo após os camponeses sem terras desbravarem os sertões chegavam os latifundiários e os expulsavam novamente, num circulo vicioso que se mantém até os dias atuais.

No processo de migração e expulsão, muitos camponeses sem terras brasileiros encontraram um terreno ainda tranquilo para se instalarem com suas famílias no Paraguai, formando comunidades conhecidas como de brasiguaios. Com a formação do lago da Usina Hidroelétrica de Itaipu milhares de camponeses foram desalojados e novamente buscaram em terras paraguaias o refugio para se instalarem.

Além desse processo de migração causado pelo não acesso à terra no Brasil, há também o processo de alinhamento da política de desenvolvimento associada do Paraguai ao Brasil, o que no caso da terra representou uma política de incentivo à médios e grandes produtores brasileiros a se instalarem no território paraguaio para "modernizar" o campo. Esse processo, levado a cabo pela aliança entre as ditaduras militares apresentava objetivos comuns e complementares entre as classes dominantes dos dois países.

No caso da classe dominante brasileira os objetivos eram primeiramente o de expandir os seus capitais para a periferia consolidando sua posição subimperialista e garantindo explorações com taxas de lucro maiores, compensando assim sua relação de dependência com os países centrais. O segundo aspecto seria o de dominar as principais produções de matérias primas e o controle sobre o comércio delas. Na esfera política dois aspectos são importantes, um primeiro de distensionar a luta pela terra no país, em especial na região sul, com a transferência de agricultores para fora dos limites das fronteiras nacionais e, um segundo, de consolidar a hegemonia e anexação econômica sobre o Paraguai.

Para as classes dominantes paraguaias, o desenvolvimento associado e dependente era uma opção, ao alinharem-se aos capitais brasileiros a burguesia paraguaia assume o papel de sócia minoritária, auferindo taxas de lucros obtidas pela 
superexploração de seu povo e da extração de suas riquezas naturais. Outro aspecto importante é a "modernização" do campo paraguaio, para a burguesia paraguaia impossível de ser realizado sem os capitais brasileiros e com o campesinato indígena. Assim a ditadura paraguaia promoveu uma Reforma Agrária às avessas, expulsando camponeses paraguaios, brasileiros e brasiguaios e entregando as terras à médios e grandes latifundiários brasileiros para a produção de grãos, em especial a soja e o algodão.

O período da articulação entre as ditaduras militares foi o período de maior expansão da presença do capital brasileiro na economia paraguaia e consolidou a dependência e o alinhamento do Paraguai ao eixo do imperialismo estadunidense e do subimperialismo brasileiro. Vuyk, afirma que é nesse período que o:

\begin{abstract}
"Paraguay transforma sus relaciones de producción en función a las necesidades del imperialismo norteamericano y subimperialismo brasilero, y pasa de un estructura principalmente agraria basada en la ganadería extensiva, a una estructura agroganadera orientada a la exportación -con el ingreso masivo del monocultivo extensivo sobre la base del latifundio-, financiera y extractivista (de energía hidroeléctrica, principalmente)."
\end{abstract}

(VUYK, 2013. p. 8)

O modelo de desenvolvimento adotado pelo Brasil e o nível industrial que alcançou ainda na primeira metade do século $\mathrm{XX}$ possibilitou as condições para a adoção de uma política expansionista sobre os países em condição mais periférica em relação ao centro capitalista.

A política subimperialista brasileira teve sua primeira experiência no Paraguai, a supremacia militar brasileira e a aliança entre as classes dominantes dos dois países foram elementos fundamentais para esse processo.

Os dois principais objetivos do subimperialismo brasileiro foi o de exportar capitais para auferirem maiores taxas de lucros no Paraguai, bem como o de dominar fontes importantes de produção de matérias primas, principalmente energia, através do Tratado Binacional de Itaipu e da produção de grãos.

O período principal de expansão do domínio brasileiro sobre o território paraguaio deu-se no seio da articulação entre as ditaduras militares dos dois países e, 
além dos elementos econômicos próprios da fase subimperialista tinham o objetivo de resolver problemas e contradições de classe e intra-classes, tanto no Brasil como no Paraguai. No Brasil o principal era por um lado, o de recompor as taxas de lucro da burguesia industrial evitando o rompimento do bloco formado com o latifúndio, e por outro destensionar a luta pela terra enfraquecendo os movimentos camponeses. No Paraguai a entrada do capital brasileiro na agricultura foi um elemento modernizante e possibilitou à burguesia paraguaia associada a participar nos lucros desse processo. Além disso, complexou a luta dos camponeses paraguaios, incluindo outros sujeitos como os camponeses e latifundiários brasileiros.

Assim, a política subimperialista desenvolvida no período de articulação entre as ditaduras militares consolidaram o domínio brasileiro sobre a economia do Paraguai em geral e o domínio de parte considerável de suas terras em especifico. Coloca-se ainda ao povo paraguaio o desafio de delinear um processo de desenvolvimento autônomo e de combater a subordinação de sua economia e a estrangeirização de suas terras. 


\subsection{Crescimento para Fora - Dependência para Dentro}

O domínio de vastas extensões do território paraguaio pelo capital brasileiro não é uma ação isolada da burguesia brasileira, como já apresentamos anteriormente, ela foi uma ação articulada entre as classes dominantes dos dois países. Marini já nos afirma que a dependência é um processo que determina as relações entre os países e entre as classes sociais internamente em cada país. Dessa forma a ação da burguesia interna paraguaia foi fundamental para por um lado o desenvolvimento da ação subimperialista brasileira e por outro ao desenvolvimento capitalista dependente paraguaio.

No que tange à colonização das terras paraguaias por brasileiros, Wagner afirma que: "Ela foi minuciosamente pensada pelas autoridades dos dois países." (WAGNER, 1989. p. 13) Já se apresentou o que isso representa para o Brasil e quais os fatores que levaram à esse processo. Para o Paraguai, ou para a sua classe dominante, isso representava uma fonte de "mão-de-obra altamente especializada em lavouras mecanizadas" (WAGNER, 1989. p. 13) para aumentar a produtividade e a presença paraguaia no mercado externo.

Para a compreensão do processo que levou a ocupação de vastos territórios paraguaios pelo capital brasileiro no período que encerra o que Marini caracterizará como a fase subimperialista de desenvolvimento é importante compreender a ação da burguesia interna paraguaia, que processos desenvolveu e com quais objetivos.

Um primeiro elemento importante de ser destacado é a ascensão do General Alfredo Stroessner ao poder em 1959 num processo em que "o Partido Colorado (Asociación Nacional Republicana - ANR) junto com as Forças Armadas, lhe deu sustentação política, mantendo-o no poder por mais de 32 anos." (WAGNER, 1989. p. 14). Para Creydt isso representou "la implantación de uma dictadura militar y policial abierta y terrorista, manejada directamente por los gobiernos, de los Estados Unidos y del Brasil, por los trusts norteamericanos, em particular por el Pentágono" (CREYDT, 2010. p. 114). A ascensão de um General formado pela Escola Superior de Guerra (ESG) brasileira configura-se somente em mais um dos elementos que ilustram a dependência paraguaia ao subimperialismo brasileiro em cooperação antagônica com o imperialismo estadunidense. 
O plano de desenvolvimento associado e dependente de Stroessner denominouse "Crescimento para fora" e buscava basicamente o aumento da presença paraguaia no mercado mundial. Já vimos anteriormente que a conformação da sociedade paraguaia pós-recolonização altamente excludente e a não adoção de politicas estruturais de redistribuição da renda e da terra impossibilitava o desenvolvimento de um mercado interno fortalecido, assim a saída para a burguesia interna paraguaia sem o rompimento com o subimperialismo brasileiro só poderia ser qualificar sua produção para exportação.

Dois elementos são fundamentais para a compreensão do plano de Stroessner, porque a questão agrária é central e porque o Brasil configura-se como o sócio principal desse modelo.

O elemento da produção agrícola e da apropriação do território torna-se fundamental devido a característica histórica da economia paraguaia, Wagner afirma que: "O forte da economia paraguaia sempre foi a agricultura, que ainda em 86 representava mais de $60 \%$ do Produto Interno Bruto (PIB), que é a soma de tudo que a nação produz." (WAGNER, 1989. p. 14) Até esse período o Paraguai exportava basicamente, segundo Wagner, gado em pé, erva-mate e algodão, sendo essa produção baseada no grande latifúndio de criação de gado e na produção "de modo artesanal pelos campesinos paraguaios" (WAGNER, 1989. p. 14).

A importância da agricultura na economia e o seu "atraso" foi a justificativa para ser esse setor o centro do plano de desenvolvimento empreendido.

A participação predominante do Brasil foi dada, por um lado, pelos limites do desenvolvimento brasileiro e pelas aspirações subimperialistas brasileiras já descritas e, por outro lado, pela subordinação da elite paraguaia ao capital brasileiro já em expansão desde a Guerra da Tríplice Aliança e, segundo Wagner, "pela proximidade geográfica e pelos vínculos econômicos existentes entre Paraguai e Brasil" (WAGNER, 1989. p. $15)$.

O plano de "Crescimento para fora" de Stroessner, segundo Wagner contava com três etapas: 
A primeira delas foi a distribuição das terras. Os tecnocratas paraguaios apontaram como região central o Alto Paraná, devido à:

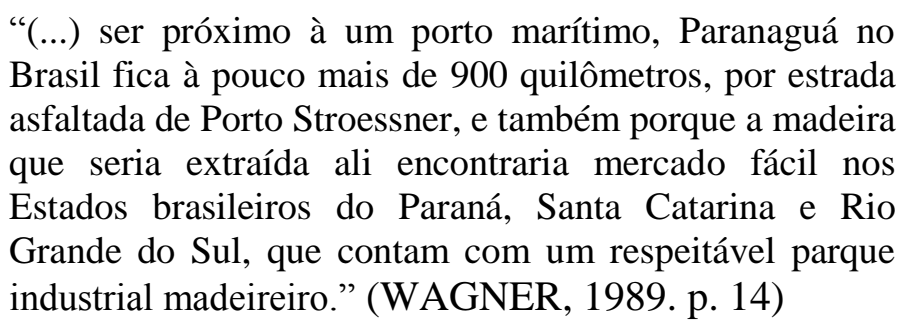

$\mathrm{Na}$ prática essa medida inicial configura-se com o processo de acumulação primitiva, já apresentado em outros períodos históricos, a madeira configura-se como uma mercadoria rápida de ser obtida devido à localização do território. A expropriação e o saque das riquezas naturais presentes no território são os elementos fundamentais dessa primeira etapa. Assim, descreve Wagner: "O governo de Stroessner confiou às grandes colonizadoras brasileiras, norte-americanas, alemãs e japonesas a tarefa de organizar a colonização" (WAGNER, 1989. p. 14). Sendo a primeira tarefa dos novos donos das terras "expulsar os campesinos paraguaios que eram considerados “indolentes para o pesado serviço de derrubar mato"' (WAGNER, 1989. p. 14).

O trabalho de expropriação das terras dos camponeses paraguaios foi facilitado pela característica de sua formação notadamente indígena, segundo Wagner eles "não tem o mesmo sentimento de posse em relação a terra que o colono brasileiro tem" (WAGNER, 1989. p. 15).

Para ocupar o seu lugar e servir de mão-de-obra para a exploração da madeira buscou-se os colonos brasileiros, porém para essa primeira fase era necessário que os colonos aceitassem as duras condições de trabalho e não comprometessem a propriedade privada das empresas colonizadoras. Dessa forma "os primeiros brasileiros a serem chamados pelo governo de Alfredo Stroessner foram os moradores das regiões Norte e Nordeste do Brasil" (WAGNER, 1989. p. 15). Segundo o autor isso foi intencionalmente construído pelas colonizadoras que "precisavam de mão-de-obra que aceitasse o papel de agregado" e assim, buscavam um colono "que não tivesse tradição de proprietário." (WAGNER, 1989. p. 15)

Os brasileiros oriundos do Norte e Nordeste segundo esse autor representaram 75 por cento dos brasileiros que migraram para o Paraguai no período de 1959 até o 
final da década de 1960. Ao chegarem os brasileiros derrubavam a mata, a madeira era comercializada pelas empresas colonizadoras e os colonos implantavam cultivos de subsistência. No final da década de 1960, afirma Wagner, Stroessner "colocou em prática a segunda etapa de seu plano” (WAGNER, 1989. p. 16), expulsar os colonos negros do Norte e Nordeste brasileiro e substitui-los pelos colonos do sul do Brasil.

Com a realidade de grande parte do território já estar desmatado, a renda da terra aumentou fortemente e o objetivo da segunda fase do plano de crescimento colocado em marcha pela ditadura paraguaia era avançar na mecanização dessas terras. Para isso " $o$ esquema publicitário montado para atrair os agricultores do Norte e Nordeste do Brasil foi desativado" (WAGNER, 1989. p. 16) e, em seu lugar foi montado um esquema para atrair os camponeses da região Sul do Brasil. Já apresentamos que esse esquema fez parte de uma articulação entre as ditaduras paraguaia e brasileira para enfraquecer os movimentos de camponeses que lutavam pela terra no Brasil, não fazer a Reforma Agrária e manter a composição do Bloco de poder formado com os latifundiários.

O autor que estamos explorando, um notável jornalista investigativo, afirma que a propaganda utilizada foi: "Com a venda de um hectare no Brasil é possível comprar mais de cinco lá no Paraguai” (WAGNER, 1989. p. 16). Wagner apresenta que:

“(...) no final da década de 1970, no Brasil, vivia-se o boom da soja, que alcançava altos preços na Bolsa de Valores de Chicago, Estados Unidos, que regula o preço dos cereais em grande parte do mundo - para o cultivo desta planta o ideal são grandes extensões de terra." (WAGNER, 1989. p. 16)

O período que olhamos a partir dos planos paraguaios é o mesmo já apresentado de expansão subimperialista brasileira, nesse período é que ocorre a consolidação da dominação brasileira sobre o território paraguaio já bastante presente no pós-guerra da Tríplice Aliança. O território estatal paraguaio, ocupado por campesinos de origem indígena sofreu uma reforma agrária às avessas, como nos afirma Creydt, a terra foi expropriada dos campesinos indígenas, entregue as empresas colonizadoras que exploraram os camponeses brasileiros "negros, mulatos e cafusos que foram as centenas para o Paraguai, com a esperança de ganhar dinheiro suficiente para comprar um naco de terra" (WAGNER, 1989. p. 15). Posteriormente essas empresas privatizaram as terras, vendendo a camponeses brasileiros oriundos do Sul. 
$\mathrm{O}$ autor em sua pesquisa, afirma que: "Com a limpeza das terras e a mecanização da lavoura, elas triplicaram de preço." (WAGNER, 1989. p. 17). Esse processo mudou profundamente a vasta região do Alto Paraná. Vejamos uma passagem do trabalho de Wagner que ilustra esse processo:

"Em menos de 15 anos a região do Alto Paraná - que equivale em números redondos a um quarto da área agricultável do Rio Grande do Sul, que é de 20 milhões de hectares, o que daria cerca de 5 milhões de hectares sofreu um imensa transformação. A Agricultura foi modernizada e a produção de soja atingiu índices jamais alcançados. A população da região, que até 1950 era de 9.531 pessoas, passou para 24.067 pessoas em $1962 \mathrm{e}$ 88.607 em 1972, segundo dados do Censo paraguaio. A taxa anual de emigração, segundo o mesmo censo, passou de $49,7 \%$, entre 1952 e 1962 , para $94,6 \%$ no período de 1962/72. O crescimento relativo do número de habitantes no Alto Paraná de 1950 à 1972 foi de 420,7\%.’'(WAGNER, 1989. p. 17)

No inicio da década de 1970 Stroessner põe em marcha a terceira fase de seu plano de modernização, assim como utilizou os camponeses negros e mestiços do norte e nordeste brasileiro, também foram usados os colonos do sul do Brasil. Com as terras mecanizadas e produzindo o governo paraguaio atuou duplamente para expulsar os camponeses brasileiros e favorecer os latifundiários também brasileiros e empresas transnacionais. Essa era a consolidação do domínio das grandes empresas e dos latifundiários capitalistas brasileiros sobre o território paraguaio. Wagner descreve dois processos vinculados a isso e o resultado dele:

No primeiro processo o governo paraguaio abandonou os camponeses a própria sorte a atuava para pressionar o empobrecimento destes, o autor relata o processo da seguinte forma: "Eles plantavam soja e algodão sem cobertura de um seguro agrícola por parte do governo de Stroessner; quando chegava a época da colheita, os preços desabavam e eles precisavam entregar a produção por preços irrisórios." (WAGNER, 1989. p. 18)

No segundo processo o governo atuava com forte repressão policial aos camponeses. Religiosos católicos e luteranos criaram o Programa de Ayuda Cristiana (PAC) para ajudar os colonos brasileiros. Wagner afirma que "muitos militantes do PAC pagaram com a vida esse serviço" (WAGNER, 1989. p. 18). As autoridades paraguaias exigiam os documentos das terras dos colonos brasileiros, mas a maioria das compras 
foram realizadas de maneira frágil e sem documentação, assim os pequenos proprietários eram expulsos das terras.

Não era de interesse do governo brasileiro, defender seus camponeses, pois estes estavam sendo expulsos para favorecer os latifundiários e as elites também brasileiras. Numa passagem da pesquisa de Carlos Wagner o autor descreve:

"No final da década de 1970, o advogado Francisco José de Vargas, de Assunção, membro do Comité de iglesias para auxilio de emergência, uma das ramificações do PAC, foi a embaixada brasileira denunciar a repressão que os colonos sofriam, e levava uma lista de pessoas desaparecidas. Foi recebido com indiferença pelas autoridades brasileiras, $\mathrm{e}$ os religiosos que o acompanhavam foram aconselhados a 'cuidar só das almas dos camponeses'.” (WAGNER, 1989. p. 19)

A passagem deixa claro a indiferença do governo ditatorial de Ernesto Geisel em relação a expropriação dos camponeses brasileiros e seu apoio aos latifundiários brasileiros, segundo Wagner, com o apoio das ditaduras brasileira e paraguaia:

"Os grandes proprietários rurais brasileiros, que até o final da década de 1960 tinham uma presença discreta no Paraguai, começaram a pressionar os pequenos e médios produtores para venderem suas terras." (WAGNER, 1989. p. 14)

Esse processo consolidou a terceira fase do plano de "Crescimento para fora" da ditadura paraguaia, sua aliança direta ao capital brasileiro subimperialista. Porém não gerou um desenvolvimento que favoreceu nem ao povo paraguaio, nem aos camponeses brasileiros atraídos pelas propagandas governamentais.

Em termos de resultado desses dois processos desenvolvidos contra os camponeses brasileiros houve um duplo movimento, a concentração da produção agrícola e da propriedade das terras sob o controle do capital brasileiro e, a nova migração ou proletarização dos camponeses brasileiros.

O primeiro movimento verifica-se por em 1986 os "brasileiros serem responsáveis pela produção de $60 \%$ das 600 mil toneladas de soja paraguaia e por mais da metade do algodão, que tem uma produção estimada em cerca de 540 mil toneladas por ano. (WAGNER, 1989. p. 20) 
O segundo movimento foi a saga dos camponeses. O autor relata que "os filhos dos colonos brasileiros se transformaram em bóias-frias nas lavouras de algodão dos grandes proprietários oriundos do Brasil" (WAGNER, 1989. p. 20), segue afirmando que muitos retornaram ao Brasil e outros migraram para outras regiões do Paraguai e para a região de Missiones na Argentina e, que, "entre estes 350 mil colonos brasileiros que viviam em 86 no Paraguai existiam, pelo menos, 60 mil sem terra." (WAGNER, 1989. p. 20)

O cumprimento das três fases do plano do governo paraguaio demonstrou claramente a aliança da elite paraguaia com o capital brasileiro, numa relação de dependência e subimperialismo, e sob a qual padeceram os campesinos paraguaios e os camponeses brasileiros engendrando uma disputa pelas terras que ressurge nos períodos atuais, sob o domínio do Capital Financeiro. 


\subsection{A Determinação do Agronegócio Brasileiro no Paraguai}

Já apresentamos no inicio deste capitulo os elementos teóricos que fundamentam a fase atual de desenvolvimento do capitalismo no campo brasileiro. A conformação de uma Economia Política do Agronegócio que só é possível, segundo Delgado, pela apropriação das rendas fundiárias determinadas pelos monopólios sobre, especialmente os recursos naturais e as terras, recolocam os elementos de dominação brasileira sobre os territórios e recursos paraguaios.

Esse processo de recomposição das taxas de lucro seja da burguesia brasileira, seja das transnacionais à ela associadas, por um lado, reforça o papel subimperialista brasileiro na dominação da economia paraguaia, e por outro, impede qualquer esforço de desenvolvimento autônomo por parte do Paraguai.

O período de articulação das ditaduras brasileira e paraguaia consolidou o processo de ocupação do território paraguaio por brasileiros. Em 1990, Wagner afirma que: "O governo do Brasil estima que existam 350 mil camponeses vivendo lá. Isso representa 10\% do total da população daquela nação." (WAGNER, 1990. p. 13) Creydt, falando sobre o "gran negócio entreguista de Itaipú" afirma uma "peligrosa penetración de trescientos mil colonos brasileros y de grandes empresas latifundistas del Brasil” (CREYDT, 2007. p. 110) no território paraguaio.

O autor já apresenta qual vai ser a contradição central do período seguinte, tal seja a expulsão dos colonos brasileiros pelos próprios latifundiários brasileiros, e a luta dos camponeses sem terra paraguaios pelo seu direito legitimo às terras entregues aos brasileiros pelos ditadores paraguaios.

Na década de 80, segundo Wagner, boa parte desses camponeses retornaram ao Brasil, expulsos por empresas brasileiras em aliança com os Generais paraguaios. O autor afirma que: “O mesmo sonho que há mais de duas décadas vem levando milhares de camponeses brasileiros a colonizarem o Paraguai os está trazendo de volta: a chance de conseguir um pedaço de terra para alimentar sua família." (WAGNER, 1990. p. 23) 
O retorno de milhares de camponeses brasileiros, expulsos pelos mesmos latifundiários brasileiros que adentram o sertão na expansão da soja, foi realizado baixo um silêncio absurdo do governo brasileiro. Wagner afirma que:

"Tudo isso aconteceu frente à um silêncio criminoso dos responsáveis pela política externa do Brasil que, em última análise, sempre mostraram-se mais preocupados em preservar os gordos lucros do capital nacional aplicado no Paraguai do que defender os direitos dos camponeses e seus aliados." (WAGNER, 1990. p. 23)

Em relação à presença atual de capital estrangeiro no domínio dos territórios no Paraguai, Vuyk nos apresenta que:

"Los últimos datos del Censo Agropecuario Nacional (CAN, 2008) demuestran que por lo menos 19,4\% del territorio nacional se encuentra controlado por extranjeros, lo que equivale a por lo menos 7.889.128 de las 40.675.200 hectáreas que posee Paraguay. De estas, por lo menos 4.792 .528 has, equivalentes al $11,78 \%$ del territorio nacional, se encuentran bajo control de propietarios brasileros." (VUYK, 2013.p. 9)

A autora prossegue acrescentando que se observarmos a quantidade de terras exploradas por brasiguaios com capitais brasileiros, propriedades de paraguaios arrendadas para brasileiros e brasiguaios, propriedades de brasiguaios naturalizados paraguaios, esse número tende a ser extremamente superior: "Con esto, el porcentaje real de tierras bajo control del capital brasilero aumenta exponencialmente." (VUYK, 2013. p. 9)

Assim, os elementos do capital financeiro na agricultura, através da conformação de uma Economia Política do Agronegócio, cuja base está na apropriação das rendas fundiárias derivadas dos monopólios das terras e dos recursos naturais recolocam na ordem do dia para a burguesia brasileira sua ação subimperialista sobre o Paraguai. Um exemplo claro desses elementos econômicos de tensão é o apoio da burguesia brasileira ao golpe que retirou presidente eleito Fernando Lugo que, não coincidentemente, se propôs a rever o Acordo de Itaipu e realizar uma Reforma Agrária que atendesse a demanda dos campesinos paraguaios expulsos na primeira fase do plano de Stroessner. Ou seja, mexer nos dois pontos centrais que determinam a ocupação econômica da burguesia brasileira no Paraguai e a apropriação das rendas de monopólio sobre a terra e a energia. 
O que observamos é a atualidade da discussão em torno a ocupação do território paraguaio pelo capital brasileiro e a função de apropriação das rendas de monopólio da terra e dos recursos naturais. A exigência da recomposição das taxas de lucro, em especial do Capital Financeiro Especulativo produz uma nova investida para a ampliação do território de exploração do capitalismo e fundamentalmente, a manutenção de sua concentração nas mãos da burguesia agrária brasileira e das transnacionais à ela associados.

Essa realidade empírica reforça o caráter da Teoria Marxista da Dependência e do Estudo da Questão Agrária como importantes chaves analíticas para a compreensão dos processos econômicos, sociais e culturais derivados da forma de inserção das economias dependentes no Mercado Mundial e, as características especificas apresentadas sob a hegemonia do Capital Financeiro Especulativo.

Em tempos de discussão sobre a integração latino-americana, a TMD recolocase com força na análise de processos que a rigor, podem fortalecer a dependência e o subimperialismo em contradição com o discurso oficial de integrar para desenvolver. 


\section{CONCLUSÃO}

O presente trabalho teve por objetivo analisar a apropriação do território pelo Capital no Brasil e no Paraguai e quais as relações que se estabelecem entre esses países, bem como os processos econômicos e sociais que derivam dessa apropriação.

Concluímos que a apropriação dos territórios que se estabeleceu no Brasil e no Paraguai posteriormente à colonização, manteve-se permanentemente sob o domínio do Capital e seguindo as leis e tendências do desenvolvimento do capitalismo de forma geral e do capitalismo dependente de forma específica.

A apropriação do território paraguaio pelo Capital brasileiro, foi desenvolvida desde a Guerra da Tríplice Aliança, mas consolida-se principalmente na expansão do Subimperialismo sob a condução política das ditaduras nos dois países. No caso exposto encerrando uma aliança entre as elites paraguaia e brasileira.

A burguesia brasileira, atuando para superar o anacronismo de sua economia sem realizar reformas estruturais, que desenvolvessem o mercado interno de massas, buscou no subimperialismo, uma saída para recompor as suas taxas de lucro, através do domínio econômico sobre as principais produções paraguaias, notadamente a produção agrícola e hidroelétrica. No caso da expansão subimperialista brasileira para o Paraguai houve, além da subordinação econômica, uma ocupação física do território paraguaio por brasileiros que na atualidade detém a propriedade privada de aproximadamente $12 \%$ do território daquele país, sem contarmos as propriedades de brasiguaios, brasileiros naturalizados paraguaios, empresas paraguaias com capital brasileiro e posses não registradas.

As elites paraguaias, representadas na ditadura de Stroessner, buscavam o desenvolvimento econômico paraguaio através de um plano denominado "Crescimento para fora", o plano da ditadura paraguaia buscou o crescimento da participação do país no Mercado Mundial através da exportação de produtos agrícolas e energia. Utilizandose para isso do Capital Brasileiro o "Crescimento para fora" aumentou a dependência e a subordinação do Paraguai. Consolidando assim um alinhamento ao subimperialismo brasileiro e ao imperialismo estadunidense.

O plano de avançar a produção agrícola paraguaia contou com três fases que se caracterizaram pela utilização e expulsão de camponeses conforme os interesses do Capital. No período anterior ao plano de Stroessner um dos principais produtos de exportação paraguaio era a erva-mate, que necessitava da mão-de-obra campesina indígena para ser extraída das matas, largamente utilizada para esse fim. Na primeira fase do plano os campesinos paraguaios foram expulsos das terras por empresas colonizadoras brasileiras, alemãs e japonesas e, substituídos pelos camponeses brasileiros oriundos das regiões Norte e Nordeste, o 'camponês sertanejo'. A mão-deobra do camponês sertanejo foi explorada para a derrubada das matas e exploração dos recursos florestais, promovendo uma acumulação primitiva apropriada pelo capital brasileiro e seus sócios paraguaios. A segunda fase do plano constituiu-se na expulsão 
dos camponeses sertanejos e a sua substituição por camponeses colonos, oriundos da região Sul do Brasil. Esses camponeses foram utilizados para mecanizar as terras e desenvolver a produção de grãos, principalmente a soja e o algodão, chegando a ser responsável por mais de $60 \%$ da produção agrícola paraguaia destinada à exportação. A terceira fase do plano constituiu-se na expulsão dos camponeses colonos e a aquisição das terras paraguaias por latifundiários capitalistas brasileiros. Aos camponeses paraguaios, sertanejos ou colonos brasileiros restou a possibilidade de serem boias-frias nas grandes fazendas de brasileiros ou migrarem para outras regiões.

O desenvolvimento do subimperialismo brasileiro no Paraguai como fruto da dependência, no caso da apropriação do território, confirma o exporto por Marini, de que a dependência é uma relação que se estabelece entre países e entre classes sociais internamente em cada país. Para as burguesias brasileira e paraguaia a relação de subimperialismo e dependência representa uma forma de recomporem as suas taxas de lucro e se apropriarem da superexploração dos trabalhadores e dos recursos naturais. Para os trabalhadores, camponeses brasileiros ou paraguaios essa relação não produz nada além de superexploração e empobrecimento, foram usados e descartados conforme os planos das classes dominantes paraguaia e brasileira.

$\mathrm{Na}$ atual fase de desenvolvimento do capitalismo no campo, caracterizado por Delgado como Economia Política do Agronegócio, engendra-se uma forma especifica de acumulação capitalista e recomposição das taxas de lucro que passa basicamente pela apropriação das rendas de monopólio, especialmente a Renda da Terra, e pela superexploração do trabalho e dos recursos naturais.

Internamente no Brasil isso repercute num aumento da pressão sobre os Territórios Camponeses (Assentamentos, Quilombos, Terras de Comunidades Tradicionais), Indígenas, Unidades de Conservação e Áreas de Preservação e, numa busca constante para redução dos direitos trabalhistas, legitimando a superexploração.

No que refere-se ao Paraguai, o ascenso do Agronegócio brasileiro, sob hegemonia do Capital Financeiro Especulativo representa mais um entrave à qualquer anseio de desenvolvimento autônomo naquela nação. O domínio territorial garantido na expansão subimperialista brasileira sob hegemonia do Capital Industrial nos governos ditatoriais, é o que garante agora a apropriação da Renda da Terra no Paraguai para recompor a taxa de lucro da Burguesia Agrária Brasileira.

O plano de Reforma Agrária do presidente paraguaio Fernando Lugo e a revisão dos termos do Tratado de Itaipu impactavam diretamente na possibilidade de extração de rendas de monopólio pelo Capital Brasileiro. Não tardou à burguesia paraguaia associada às classes dominantes brasileiras e ao imperialismo estadunidense defender os seus interesses e o de seus sócios maiores, no dia 22 de junho de 2012, com apenas dois dias de 'julgamento' o presidente Fernando Lugo foi deposto com forte apoio da Burguesia Agrária Brasileira. 
Desta forma, observamos que o subimperialismo brasileiro sobre o Paraguai continua desenvolvendo-se, com novas características determinadas pelo estágio de desenvolvimento do capitalismo à nível global e a determinação que esse exerce sobre a produção agrícola e a apropriação dos territórios nos países dependentes. Logicamente que esse subimperialismo engendrou novas características não descritas pelos intelectuais utilizados nesse trabalho e que ainda colocam-se como desafios na Teoria Marxista da Dependência.

Reforça-se assim, a afirmação de Marini, de que o desenvolvimento das nações Latino Americanas só será possível com a supressão da Dependência, e, que essa só pode ser obtida pela superação propriamente dita do Sistema Capitalista.

"A consequência da dependência não pode ser, portanto, nada mais do que maior dependência, e sua superação supõe necessariamente a supressão das relações de produção nela envolvida."

Ruy Mauro Marini, Dialética da dependência, 1973. 


\section{REFERÊNCIAS}

ALMEIDA FILHO, Niemeyer. (org) Desenvolvimento e Dependência: cátedra Rui Mauro Marini. Brasília: Ipea, 2013.

BAMBIRRA, Vânia. O Capitalismo dependente latino-americano. Florianópolis: Insular, 2012.

CALDART, Roseli Salete. (org) Dicionário da Educação do Campo. São Paulo: Escola Politécnica de Saúde Joaquim Venâncio, Expressão Popular, 2012.

CODAS, Gustavo. (org) O direito do Paraguai a soberania: a questão da energia Hidroelétrica. São Paulo: Expressão Popular, 2008.

CREYDT, Oscar. Formación Histórica de la Nación Paraguaya. Assunción, Paraguay: ServiLibro, 2010.

CREYDT, Oscar. Frente al peligro brasilero: lucha unida de todos los patriotas. 1870 - 1970 “¡Vencer o Morir!”. Asunción: Editora Adelante, 2004.

DELGADO, Guilherme Costa. Do "capital financeiro na agricultura" à economia do agronegócio: mudanças cíclicas em meio século (1965-2012). Porto Alegre: Editora da UFRGS, 2012.

GALEANO, Eduardo H. As veias abertas da América Latina. tradução de Sérgio Faraco. Porto Alegre: L\&PM, 2011.

IPEA. Comunicado no 96 do Ipea: Código Florestal: implicações do PL 1876/99 nas áreas de reserva legal. Brasília: IPEA, 2011.

MARINI, Ruy Mauro. Subdesenvolvimento e Revolução. Florianópolis: Insular, 2012.

MARINI, Ruy Mauro. Dialética da dependência. In: TRASPADINI, Roberta; STÉDILE, João Pedro. (orgs) Ruy Mauro Marini - vida e obra. São Paulo: Expressão Popular, 2005; p. 137-180.

MARINI, Ruy Mauro. Desenvolvimento e dependência. In: TRASPADINI, Roberta; STÉDILE, João Pedro. (orgs) Ruy Mauro Marini - vida e obra. São Paulo: Expressão Popular, 2005; p. 221-224.

MARX, Karl. O Capital: crítica da economia política: livro I. tradução de Reginaldo Sant'Anna. Rio de Janeiro: Civilização Brasileira, 2006.

MARX, Karl. O Capital: crítica da economia política: livro II. tradução de Reginaldo Sant'Anna. Rio de Janeiro: Civilização Brasileira, 2011.

MARX, Karl. O Capital: crítica da economia política: livro terceiro: o processo global de produção capitalista. tradução de Reginaldo Sant'Anna. Rio de Janeiro: Civilização Brasileira, 2008. 
MORAES, Clodomir Santos de. História das Ligas Camponesas no Brasil. Brasília: Edições Iattermund, 1997.

NETTO, José Paulo \& BRAZ, Marcelo. Economia Política: uma introdução crítica. São Paulo: Cortez, 2007.

PORTELLI, Hugues. Gramsci e o bloco histórico. tradução de Angelina Peralva. Rio de Janeiro: Paz e Terra, 1977.

RIBEIRO, Darcy. O povo brasileiro: a formação e o sentido do Brasil. São Paulo: Companhia das Letras, 2006.

SERRA, José. (coord.) América Latina: ensaios de interpretação econômica. Rio de Janeiro: Paz e Terra, 1979.

STÉDILE, João Pedro. (org) A Questão Agrária no Brasil: O debate tradicional 1500 à 1960. São Paulo: Expressão Popular, 2005.

STÉDILE, João Pedro. (org) A Questão Agrária no Brasil: O debate na esquerda 1960 à 1980. São Paulo: Expressão Popular, 2007.

STÉDILE, João Pedro. (org) A Questão Agrária no Brasil: Programas de Reforma Agrária - 1946 à 2003. São Paulo: Expressão Popular, 2007.

STÉDILE, João Pedro. (org) A Questão Agrária no Brasil: história e natureza das Ligas Camponesas -1954 à 1964. São Paulo: Expressão Popular, 2006.

STÉDILE, João Pedro. (org) A Questão Agrária no Brasil: A classe dominante agrária - natureza e comportamento - 1964 à 1980. São Paulo: Expressão Popular, 2006.

STÉDILE, João Pedro. (org) A Questão Agrária no Brasil: O debate tradicional 1500 à 1960. São Paulo: Expressão Popular, 2005.

SWEEZY, Paul et. all. A transição do feudalismo para o capitalismo. tradução de Isabel Didonnet. Rio de Janeiro: Paz e Terra, 1977.

VUYK, Cecilia. Subimperialismo brasilero y dependencia paraguaya: análisis de la situación actual. Buenos Ayres: CLACSO, 2013.

VUYK, Cecilia. El debate de la dependencia en el estudio de la relación ParaguayBrasil en los 70 en la bibliografía paraguaya (Tese para obtenção de título de Licenciada em Ciência Política, Universidad Católica de Asunción) Asunción, 2012.

WAGNER, Carlos. Brasiguaios: Homens sem Pátria. Petrópolis: Vozes, 1990. 
ZAVASKI, Cledinei C. Contradições no bloco do agronegócio: a disputa pela apropriação de mais-valia, a apropriação de territórios e o aumento da exploração dos trabalhadores. (Artigo para obtenção de título de Especialista em Economia e Desenvolvimento Agrário, Universidade Federal do Espirito Santo) Vitória, 2011. 